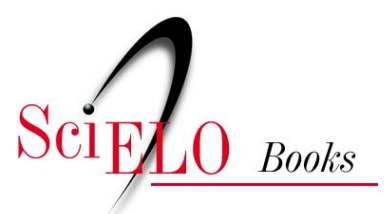

\title{
Psicologia social
}

estratégias, políticas e implicações

Nelson Eduardo Estamado Rivero (org.)

RIVERO, NEE., org. Psicologia social: estratégias, políticas e implicações [online]. Rio de Janeiro: Centro Edelstein de Pesquisas Sociais, 2008. 119 p. ISBN: 978-85-9966-286-1. Available from SciELO Books $<$ http://books.scielo.org $>$.

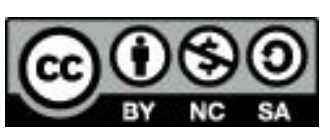

All the contents of this chapter, except where otherwise noted, is licensed under a Creative Commons Attribution-Non Commercial-ShareAlike 3.0 Unported.

Todo o conteúdo deste capítulo, exceto quando houver ressalva, é publicado sob a licença Creative Commons Atribuição Uso Não Comercial - Partilha nos Mesmos Termos 3.0 Não adaptada.

Todo el contenido de este capítulo, excepto donde se indique lo contrario, está bajo licencia de la licencia Creative Commons Reconocimento-NoComercial-CompartirIgual 3.0 Unported. 


\section{BIBLIOTECA VIRTUAL DE CIÊNCIAS HUMANAS}

\section{PSICOLOGIA SOCIAL: ESTRATÉGIAS, POLÍTICAS E IMPLICAÇÕES}

Nelson Eduardo E. Rivero Organizador 


\section{Nelson Eduardo E. Rivero \\ Organizador}

\section{Psicologia Social: Estratégias, políticas e implicações}

Rio de Janeiro

2008 
Esta publicação é parte da Biblioteca Virtual de Ciências Humanas do Centro Edelstein de Pesquisas Sociais - www.bvce.org

Copyright (c) 2008, Nelson Eduardo E. Rivero

Copyright (C) 2008 desta edição on-line: Centro Edelstein de Pesquisas Sociais Ano da última edição: 2001

Nenhuma parte desta publicação pode ser reproduzida ou transmitida por qualquer meio de comunicação para uso comercial sem a permissão escrita dos proprietários dos direitos autorais. A publicação ou partes dela podem ser reproduzidas para propósito não-comercial na medida em que a origem da publicação, assim como seus autores, seja reconhecida.

ISBN 978-85-99662-86-1

Centro Edelstein de Pesquisas Sociais

www.centroedelstein.org.br

Rua Visconde de Pirajá, 330/1205

Ipanema - Rio de Janeiro - RJ

CEP: 22410-000. Brasil

Contato: bvce@centroedelstein.org.br 


\section{Sumário}

Apresentação

Nelson Eduardo Estamado Rivero

PARTE I - MESAS REDONDAS E SEMINÁRIOS ABERTOS

Psicologia Social: Teoria e Prática ...........................................................5 Silvia T. Maurer Lane

Psicologia Social: estratégias, políticas e implicações Pedrinho A. Guareschi

Sociabilidade autoritária e abolição do castigo .31 Edson Passetti

Cultura Brasileira - diagnóstico do presente José Paulo Bisol

Intervencion e campo de intervencion .57 Alejandro Raggio

Elogio de la herejía Gabriel Eira

Pensando em armas para a desinstitucionalização da psicologia social ......78 Tania Mara Galli Fonseca

PARTE II - GRUPOS DE TRABALHO

Pesquisa em Psicologia Social: de onde viemos e para onde vamos .86 Neuza M. F. Guareschi

Por uma psicologia que se diz social: contemporaneidade, tecnologia e subjetividades ..... Deise Juliana Francisco

Práticas institucionais .
Psicologia comunitária e intervenções em grupos populares Maria Luisa Menezes

Manifesto para uma atualização da Psicologia Social

Marília Veríssimo Veronese 


\section{Apresentação}

Este livro é um dos resultados do VIII Encontro Regional Sul da Associação Brasileira de Psicologia Social (ABRAPSO), realizado no campus da Universidade Federal de Santa Maria, no Rio Grande do Sul, Brasil.

Um dos resultados porque somos sabedores que um acontecimento produz múltiplos encontros e afecções; que dele é possível uma diversidade de linhas de pensamentos e ações, linhas de fuga, rompimentos, construções, destruições e subjetivações. Até mesmo, linhas de reação, conservação e manutenção. Por isso, o que temos em mãos está distante de uma síntese do encontro, longe de caracterizar a unidade de um discurso, mas sim, saudavelmente, apontar para a multifonia, para a diferença. Chama a atenção para sinfonias dissoantes, para os compassos harmônicos que compõe músicas que inventam a vida, que improvisam novas melodias que se ouviram em Santa Maria. Oferece visibilidade às alianças possíveis e às distancias necessárias; assumir a possibilidade de viver e criar com as diferenças na Psicologia Social. Desde que, é óbvio, disponibilizem-se ao envolvimento intenso de uma prática social ética e política.

Para cumprir com o objetivo de ser esta janela para olhares diferentes, este livro contém uma primeira parte, que é composta pelos textos oriundos das mesas redondas e dos seminários abertos realizados no Encontro. Os autores participaram destes acontecimentos como integrantes das mesas e responsáveis pelos seminários e são eles: Sílvia T.M. Lane, Pedrinho Guareschi, Edson Passetti, José Paulo Bisol, Alejandro Raggio, Gabriel Eira e Tânia Mara Galli Fonseca. Uma segunda parte é composta por textos resultantes das discussões dos grupos de trabalho realizados durante dois dias no Encontro. Os autores destes textos participaram dos grupos e assumiram o papel de coordenadores dos grupos, responsabilizando-se também por redigir o que ora se apresenta. São eles: Neuza M.F. Guareschi, Deise Juliana Francisco, Marília Veronese e Ana Luisa Menezes. Ao final, encontra-se um manifesto sobre Psicologia Social, de autoria de Gregório Baremblitt que impossibilitado de atender o convite para participar do Encontro enviou-o para ser lido e permitiu sua publicação neste livro. Em anexo, está o programa oficial do VIII Encontro Regional Sul da ABRAPSO e a comissão organizadora.
Aproveito para registrar o enorme agradecimento do evento ao grupo de alunos do Curso de Graduação da UFSM que participou da comissão organizadora e que se fez decisivo no desenvolver das atividades, assim como, agradecer a todos que de uma forma ou de outra contribuíram para sua realização.

Este encontro teve como tema: "Psicologia Social: políticas, estratégias e implicações". Tema pensado para possibilitar o múltiplo e para dar força ao movimento necessário dos territórios de luta de uma Psicologia que se quer engajada, política e socialmente. Pois se uma das tradições da ABRAPSO é a convivência, a troca, a crítica e a situação de cumplicidade entre seus associados e simpatizantes, outra das suas características é ter nascido para a ação implicada, para a luta, para ser voz e corpo na busca de um mundo mais saudável e justo.

Nelson Eduardo Estamado Rivero Núcleo de Santa Maria - REGIONAL SUL - ABRAPSO 


\section{PARTE I - MESAS REDONDAS E SEMINÁRIOS ABERTOS}

\section{Psicologia Social: Teoria e Prática}

\section{Silvia T. Maurer Lane}

\section{I - A Situação Atual}

Sabemos que a Psicologia surgiu, como área científica e profissional, no Brasil, sob duas égides: a da Medicina e a da Educação. A primeira entendia a psicologia como uma prática curativa dos distúrbios mentais, e a segunda visava uma ação preventiva. Porém, as condições sócioeconômicas do país privilegiavam o modelo médico, propiciando um ‘status' ao psicólogo clínico.

Trabalhos e experiências significativas como os de Lourenço Filho e Helena Antipof não tiveram a força suficiente para competir com a figura poderosa do "doutor". (Só os psicólogos clínicos são tratados por doutor...)

Quando a profissão e o currículo dos cursos de psicologia foram regulamentados por lei, em 1962, havia a preocupação de uma formação polivalente: clínica, trabalho e educação, porém, na realidade os cursos priorizavam a formação em clínica, mais devido a demanda dos alunos do que por um principio educacional.

Há um outro ângulo a ser considerado, tradicionalmente o prestígio do médico significava ganho elevado, enquanto desprestigio da educação se traduzia em baixos salários - que reforçava o modelo médico para o psicólogo.

Pesquisas realizadas por Conselhos Regionais e Federal de Psicologia, apresentaram resultados assustadores quanto ao exercício da profissão, mostrando que uma alta porcentagem dos psicólogos - registrados - não vivem de sua profissão pois dedicam apenas algumas horas semanais a ela, insuficientes para garantir uma sobrevivência financeira.

A tese de doutorado de Sergio Ozella constatou em 1983 a existência de 74 cursos de psicologia em todo o país, e, dez anos depois eram mais de cem. Se considerarmos uma média de 100 alunos que se formam anualmente em cada curso, teremos em torno de 10 mil psicólogos ingressando no mercado de trabalho. O que estarão fazendo estes profissionais?

Sem dúvida há um grande contingente batalhando por uma clínica, com poucos pacientes, porém amparados financeiramente por outros.

Aqueles que necessitam sobreviver de sua profissão vão à procura de empresas e indústrias, na qualidade de psicólogos organizacionais e/ou de recursos humanos. Os salários são razoáveis, porém sofrem um forte preconceito oriundo das universidades: "se V. trabalha para um capitalista, direta ou indiretamente, V. está explorando o trabalhador...".

Enquanto isso, o psicólogo educacional desenvolveu muitos estudos e pouca prática - o cargo existia em escolas particulares, e, há alguns anos, ele foi criado em escolas públicas.

A dissertação de Mestrado de Wanda Maria Junqueira Neves demonstrou como esses profissionais não têm clareza sobre suas funções e atribuições. Fazendo de tudo ou nada nas escolas. Porém, eles continuam a velha discussão sobre qual é a diferença entre o psicólogo educacional e o escolar... E eles continuam fazendo 'clínica', ou seja, atendendo individualmente, as crianças 'ditas' problemáticas quanto à aprendizagem e ao comportamento. Existem exceções muito bem sucedidas, em geral, em escolas particulares onde existem condições de manter equipes de profissionais escolhidos a dedo... E, razoavelmente bem pagos...

Mas, via de regra, ele é um profissional à procura de sua identidade...

Este parece não ser o problema do psicólogo clínico, pois ele é o doutor, (curador ou... curandeiro?). A ausência de uma coerência entre teoria e prática, ou, entre saber e fazer, acabam levando a práticas ecléticas, que priorizam a sensibilidade como o seu guia.

Da mesma forma como encontramos psicólogos freudianos, yunguianos, psicodramatistas, behavioristas, etc., também existem aqueles para os quais tudo é válido, como o Tarô, o I Ching ou o Horóscopo, como recursos para diagnosticar o porque do sofrimento de alguém, isto, quando não apelam para energias cósmicas ou terapias de vidas passadas. 
Também gosto de consultar o I Ching e ler o meu horóscopo, mas ciente de estar em outro nível- o da crença, não o do saber científico. Pois, a dúvida acompanha sempre o "oráculo".

Quando afirmamos que o psicólogo está à procura de sua identidade, queremos dizer que as teorias e técnicas apreendidas, só têm valor se submetidas a uma análise crítica de quanto elas permitem atingir os objetivos propostos.

A ciência é um saber humilde. Ela parte da ignorância, e questiona: "será que pode ser assim?" Se for, ela deve demonstrar por "a+b" a sua descoberta, sem deixar dúvidas, apenas mais questões a serem investigadas.

Qualquer que seja a prática do psicólogo, curativa ou preventiva, ele poderá desenvolvê-la no sentido de fazer com que o sujeito de seu trabalho se reconheça como uma individualidade construída por um contexto sócio-histórico.

Ou seja, trata-se de um organismo peculiar que se desenvolve através do conjunto de suas relações, as quais acontecem perpassadas pela lógica e ideologia das instituições, que definem os papéis sociais, as normas, os valores e os objetivos a serem atingidos.

Em outras palavras, cabe ao psicólogo optar por uma prática que vise sempre o desenvolvimento pleno da subjetividade constituída pelas categorias fundamentais do psiquismo humano e das funções psicológicas superiores, como a memória, a imaginação e a cria ti vida de - instrumentos indispensáveis para a liberdade do ser humano, segundo Vigotski (1996).

Enquanto a Universidade não romper com o círculo vicioso criado entre um saber congelado que leva à técnicas reprodutivas de um 'status quo', ela só conseguirá atender a uma elite intelectual e econômica, para a qual convém manter as coisas como estão...

Também na sua prática cotidiana, cabe à Universidade contribuir para o avanço da consciência dos futuros psicólogos, pois somente eles poderão desenvolver atividades transformadoras da sociedade.

Um bom exemplo deste processo ocorreu no Departamento de Psicologia Social da Faculdade de Psicologia da PUC-SP; há uns 20 anos atrás, seus professores procuravam desenvolver nos alunos uma postura crítica em relação às teorias tradicionais da psicologia social, principalmente, nos primeiros semestres do curso.

$\mathrm{Na}$ ocasião da formatura desses alunos, nenhum professor do Departamento é sequer homenageado, apesar de relações amistosas existentes entre eles. Questionando os alunos o por que dessa 'descriminação', eles alegaram a insegurança que suas aulas geravam em relação às técnicas e práticas que definem a profissão: "perdiam o pé e não sabiam o que fazer".

Quando nossas pesquisas permitiram sistematizar um saber e, consequentemente, levar à revisão do conteúdo das disciplinas ministradas pelo Departamento, houve uma reversão significativa deste quadro, pois elas passaram a dar novos subsídios teóricos para a prática e para uma análise crítica tanto da realidade social como das técnicas utilizadas.

E aconteceu que os professores do Departamento de Psicologia Social, foram os mais votados para a direção da Faculdade, assim como para serem paraninfos dos formandos.

\section{II - Da comunidade para as instituições}

Este desafio começou durante o I Encontro Nacional sobre Trabalho Comunitário, realizado em Belo Horizonte, MG, em 1992.

Foi um marco histórico em vários sentidos. Um em especial, chamou a minha atenção: a cisão entre os analistas institucionais e os psicólogos comunitários, que ora assumia cores políticas, ora científicas.

$\mathrm{Na}$ realidade os dois grupos tinham o mesmo objetivo, ou seja, o desenvolvimento das consciências individuais e sociais, das pessoas envolvidas no processo de intervenção, tanto institucional como comunitária.

A explicação desse conflito é óbvia: enquanto na América Latina a "brecha" era a Psicologia Comunitária, no Primeiro Mundo as Instituições abriam suas portas para os psicólogos analisarem as relações sociais existentes, e as intervenções possíveis.

A divergência, provavelmente, surgiu através da formação profissional das pessoas envolvidas: havia aqueles que por diversas 
contingências foram para o exterior, em geral, para a França, e adquiriram uma experiência de trabalho em institucionais.

$\mathrm{O}$ outro grupo se constituiu por atividades desenvolvidas em intervenções em comunidades. Aqueles que permaneceram na América Latina durante os períodos de ditadura e/ou repressão política procuraram por "brechas" de resistência e atuação, sob a inspiração de Paulo Freire e muitos outros.

Autores como Lapassade, Loureau, Guattari, foram lidos e discutidos, porém, eles partiam de vínculos institucionais, os quais naquele momento, eram inviáveis, pois as instituições no poder fechavam suas portas aos" subversivos"

Apenas as Comunidades Eclesiais de Base e algumas Associações de Amigos de Bairros abriam espaço para um trabalho junto às populações envolvidas.

Fatos semelhantes ocorreram no Chile, Peru, Colômbia, Venezuela e México e foram relatados na obra organizada por Esther Wiesenfeld e Euclides Sanchez (1995), intitulada "Psicologia Social Comunitária en América Latina". E, em um artigo menos extenso publicado na Intemational Revue of Applied Psychology, (1991).

Eu e Bader Sawaia contamos esta história tanto como um capítulo do livro como num item do artigo.

A grande meta era sempre a procura de soluções para os problemas sociais através do desenvolvimento da autonomia dos indivíduos e das comunidades.

Com a abertura política, a Psicologia Comunitária passa a ser disciplina curricular em alguns cursos de Psicologia, com estágios desenvolvidos por professores e alunos. Fora da Universidade ela consiste em trabalho voluntário, realizado, em geral, nos fins de semana. Durante todo este período, não conseguimos resposta para uma questão crucial: quem deve remunerar esse trabalho?

Por outro lado o termo tomou-se um modismo, valendo qualquer intervenção ou mesmo descrição em bairros da periferia, como bem demonstrou M. Fátima Quintal de Freitas, em sua tese de doutorado.
Finda a ditadura, os antigos militantes políticos começaram a propor a criação de cargos para os psicólogos em instituições como: creches, postos de saúde, escolas, hospitais, etc. todos de caráter público, remunerados pelo Estado.

Dentro da lógica do capitalismo, como já dissemos, educação, saúde e prevenção não são prioridades, o que se traduz por baixos salários, o que tornam essas atividades pouco atraentes diante do modelo clínico-médico.

Porém, a consciência social e política de muitos psicólogos os levaram a assumir esses cargos, com dedicação e entusiasmo, porem, defrontaram-se com uma séria pergunta: "o que fazer"?

$\mathrm{E}$, o círculo se fecha, pois os cursos, em geral, não prepararam seus alunos para o trabalho em instituições dessa natureza, e novamente, presenciamos práticas de ensaio-eerro, pois as próprias instituições não têm clareza de suas atribuições, confundido-o com o assistente social e/ ou educador. Encontramos de novo o psicólogo à procura de sua identidade..

Se a psicologia voltada para a comunidade e instituições públicas parece ser um avanço, não significa que devemos nos esquecer as outras especializações, mas sim repensálas criticamente, em termos de compromisso social.

É possível o psicólogo do trabalho, priorizar o trabalhador, assim como o educacional enfocar a qualidade das relações sociais na escola, visando sempre uma atuação preventiva e nunca de "panos quentes". Assim como o psicólogo clínico não deverá jamais esquecer que a doença mental é sempre social..

Tudo indica que eles contribuíram, significativamente, para a formação profissional desses alunos.

A moral da história se resume: não basta à Universidade fazer teorias dissociadas de uma prática, seja ela em sala de aula, no consultório, na escola, na empresa, assim como na pesquisa e na sistematização do saber.

A sua função não termina na outorga de um diploma, pois a Universidade deve se inserir na realidade cotidiana daqueles que "estão lá fora", constituindo sociedades, culturas, países, enfim, a Humanidade. 
Enquanto os cursos de Psicologia não romperem o círculo vicioso criado entre um saber consagrado que se traduz em técnicas e práticas reprodutivas, mantendo, assim, o 'status quo', validando um saber que só atende a uma elite social, para a qual convém manter o estado de coisas..

Porém, se a Psicologia, procurar uma inserção social mais ampla, prestando serviços - direta ou indiretamente para a grande maioria da população, e desta forma colaborar para a solução das injustiças sociais e da alienação social do ser humano, ela poderá sistematizar saberes para que o profissional junto com a população possam enfrentar seus problemas e dúvidas do dia-a-dia, e encontrar soluções, e propiciar o desenvolvimento da autonomia da comunidade.

E na sua prática cotidiana cabe também aos professores de Psicologia contribuírem para o avanço da consciência dos futuros profissionais, pois é o psicólogo consciente da realidade sócio-histórica na qual está inserido, que desenvolverá atividades transformadoras.

Esta é a Utopia. Porém, hoje as exceções à regra demonstram que ela é viável, mas para tanto é necessário manter uma troca constante entre uma Universidade crítica, um profissional questionador, e a própria comunidade com suas necessidades prementes, levantando questões a serem pesquisadas. Estas, por sua vez, levarão a sistematizações teóricas, as quais deverão atualizar a formação dos novos psicólogos.

A pesquisa do cotidiano apresenta uma consequência muito importante - a de tornar os sujeitos, direta e/ou indiretamente coparticipantes do saber desenvolvido, o qual terá, necessariamente, consequências práticas. Para tanto é preciso saber comunicar o nosso conhecimento numa linguagem acessível, precisa, porem compreensiva.

Para finalizar quero mencionar algumas contribuições que o nosso núcleo de pesquisa na PUCSP vem elaborando.

Temos constatado que, no plano individual, as emoções, a linguagem e o pensamento são mediações que levam a agir, portanto somos as atividades que desenvolvemos na sociedade, através da mediação dos grupos sociais dos quais, necessariamente, participamos e desenvolvemos a nossa consciência da realidade que nos cerca, através do pensamento e das emoções - afetividade - que permeiam as relações com nossos pares, nos identificando como individualidade - identidade.

Verificamos, também, que as Instituições sociais são produtoras de ideologia, que tem a sua eficácia garantida, não apenas racionalmente, mas pelos códigos afetivos que utilizam para transmiti-la.

Se estas mensagens não forem decodificadas pela linguagem e pensamento, elas se tornam fragmentos que podem inibir o avanço da consciência, dar falsos significados a nossa atividade, constituir características da afetividade, e através do desempenho de papéis prescritos, cristalizar a identidade.

Deslindados todos estes processos, acreditamos que a psicologia sócio-histórica trará contribuições para a compreensão da Ética e da Estética, levando a práticas que aprimorem moralmente o ser humano no conjunto de suas relações sociais, e também levem-no a desenvolver o seu potencial criativo, embelezando o seu dia-a-dia, contribuindo para a plena concretização da Cidadania.

\section{Referências Bibliográficas:}

LANE, S.T.M. e SAWAIA, B.B. "Comunity Social Psychology in Brasil" In. Applied Psychology: An International Review, 1991, 40 (2), p. 119-142.

LANE, S.T.M. e SAWAIA, B.B. (1995). "La Psicologia Social Comunitaria en Brasil", in Contribuiciones Latino-Americanas para la Psicologia Social Comunitária. eds, Wiesenfeld, E. e Sanchez, E. Caracas, Fondo Ed. Tropykos.

VIGOTSKI, LS. (1990-1995). Obras Escogidas, Madrid, Vizor dist. 


\section{Psicologia Social: estratégias, políticas e implicações}

Pedrinho A. Guareschi

\section{Introdução}

A ABRAPSO (Associação Brasileira de Psicologia Social), através de seus congressos, encontros, publicações etc., tem-se distinguido, de maneira marcante, em tentar superar impasses, produzir novas sínteses, ligar teoria e prática, mostrar a importância de se tomar em consideração a história e as ações dos seres humanos etc. Um rápido olhar sobre essas produções nos deixam claras essas questões que, do ponto de vista duma postura mais tradicional e supostamente ortodoxa, podem parecer, além de estranhas, até mesmo atemorizadoras ou escandalosas. Vejamos, apenas como exemplo, os três volumes publicados pela Abrapso-Sul nos últimos encontros bienais: Ética e Relações Sociais, em 1985 (Jaques et al. 1985), onde, surpreendentemente, os participantes se decidem a discutir a presença da ética nas relações sociais; Psicologia e Práticas Sociais em 1997 (Zanella et al. 1997), onde se coloca na mesa de discussão essa questão momentosa e dolorosa: qual a prática da Psicologia Social? E finalmente, em 1999, o livro Cidadania e Participação Social (Silveira et al. 1999), onde nos perguntamos o que a psicologia social tem a ver com a questão política, enfatizando duas dimensões centrais da política: o significado do ser cidadão, e a questão da participação como estratégia central da prática política.

Evidentemente, não estamos falando aqui das primeiras discussões, quase que heróicas, iniciadas por Sílvia Lane, no final da década de 70 e inícios da década de 80, com a publicação de seus dois livros: O que é Psicologia Social (Lane, 1981) e O Homem em Movimento (LaneeCodo, 1984). A empreitada, naqueles momentos, foi de tentar mostrar que existia uma outra psicologia social. As palavras "histórico/a", "movimento", eram termos não muito bem aceitos naquelas circunstâncias.

Chegamos assim a esse Encontro Regional com um novo desafio: estratégias, políticas e implicações. A impressão que tais termos nos dão é de que se faz importante, e já é tempo, de passarmos a discutir alternativas, estratégias e políticas novas, tendo sempre em mente as implicações que, consequentemente, se atravessam em nosso caminho; em outras palavras, ter consciência dos riscos que toda estratégia e toda política acarreta.
Gostaria, nesse pequeno espaço que me é proporcionado, fazer uma rápida memória, situando a caminhada da psicologia social de suas origens até os dias de hoje (a); e apontar, de maneira preliminar e utópica, para forças e luzes que, algumas, arriscam mostrar seu rosto, ou, outras, mal se vislumbram no horizonte (b).

\section{a) Uma rápida memória}

Sem memória não há história, dizem os filósofos da ciência. E "quem não conhece sua história, está condenado a repeti-la; mas ela não pode ser repetida a não ser em forma de farsa ou de tragédia", como nos preveniu o velho Marx.

Temos um livro, escrito em 1998, e publicado em português em 1999, que é fundamental a todos os que querem conhecer a história da Psicologia Social: o livro de Robert Farr, Raízes da Moderna Psicologia Social (Farr, 1999), em que o autor, após 25 anos de investigação, deixa claro a caminhada dessa ciência, desde suas origens, até os nossos dias. Em traços extremamente rápidos, pode-se dizer que ela teve suas origens em Wundt, dentro do seu projeto tríplice de: primeiro, criar um laboratório para experiências, juntamente com uma revista científica para comunicação de resultados; segundo, fazer uma discussão filosófica (metafísica e epistemológica) sobre a psicologia; e terceiro, escrever dez volumes inteiros sobre Psicologia Social, sua Volkerpsychologie. Devido a diversos caminhos e descaminhos, nossa ciência sofreu algumas discussões nos inícios de nosso século, mas fincou raízes profundas nos Estados Unidos, onde se reduziu a uma Psicologia Social experimenta lista e individualista, bebendo das vertentes teóricas do cartesianismo e do positivismo.

Após a II Guerra Mundial, num Plano Marshall acadêmico, ela retoma à Europa onde estende seus tentáculos, tentando universalizar-se como a única psicologia social possível As resistências começam principalmente na França, a partir da década de 70, com os estudos de Moscovici e Israel e Tajfel. Na América Latina ela domina tranquilamente até a década de 80, quando começa a ser questionada também por aqui, a partir da Venezuela, Brasil etc. por professores e pesquisadores ligados a associações como a A VEPSO (Associação Venezuelana de Psicologia Social) e a ABRAPSO. 
Que tipo de psicologia era essa? Uma psicologia que nunca encontrou o "social". Para ela, principalmente para a linha americana (do Norte), o social, na realidade, não existe. O que existe é uma soma de individuais, de singulares.

$\mathrm{Na}$ França essa psicologia não foi aceita, pois a herança da França era mais sociológica, e o social fazia parte de suas tradições e investigações. Mas o social que por lá se criou foi um social reificado, um social "coisa", que não conseguia garantir a singularidade e a subjetividade das pessoas. Não foram, certamente, Durkheim e Comte os culpados pelos totalitarismos e coletivismos que se espalharam por muitos países da Europa; mas alguma raiz está certamente presente nas elucubrações dos primeiros descobridores do social.

A grande pergunta que permanece ainda não respondida é por que George H. Mead, com seu conceito de self, nunca conseguiu fincar pé, com solidez, em algum país.

O conceito de "representações sociais", com todas as distinções feitas no decorrer de sua história, é uma tentativa de resposta a essa grande questão: o que é social em Psicologia Social.

$\mathrm{Na}$ realidade, uma psicologia bem diferente surge a partir da década de 70 na França, e da década de 80 na América Latina; e a ABRAPSO é, em grande parte, responsável por essa mudança entre nós, e está escrevendo, de maneira significativa, o registro dessa história.

Que se pode dizer do momento atual?

Para o caso brasileiro, convivemos hoje com uma pluralidade de enfoques, uma confluência de diferentes visões, que provêm ainda em parte do Hemisfério Norte, principalmente dos Estados Unidos, mas também de outras paragens, como da França, Inglaterra e, sem serem enfoques totalmente novos, alguns que fizeram pouso na Espanha. Também não se podem esquecer as partilhas muito frutíferas feitas com alguns países da América Latina, principalmente com a Venezuela. Os novos questionamentos à Psicologia social não vêm mais tanto da linha experimentalista-positivista, mas principalmente de posturas novas, ligadas à Teoria Crítica, à Esquizoanálise, à Teoria das Representações Sociais, ao Construcionismo Social, etc. Há sinalizações de algumas questões mais recentes, ainda não bem definidas, um tanto flutuantes, como certas influências da assim chamada pós-modernidade, que muitas vezes se prendem a um tipo de discursivismo. Não sabemos o quanto disso vai se concretizar, e de que maneira.

Mas há também algumas luzes, que já podem ser identificadas com mais clareza, que apontam para novas direções, e talvez novos paradigmas. E sobre isso que nos arriscamos falar, com cuidado e humildade.

\section{b) $\mathrm{O}$ futuro por criar}

Seleciono agora alguns tópicos que, no meu entender, apontam para algo novo. São tópicos; não são necessariamente teorias já aprofundadas. Mas são luzes novas, provocadoras, e trago-as à discussão, pois elas têm a ver, todas elas, com Estratégias, Políticas e Implicações, na medida em que estão sempre dirigidas a uma prática, e a superação da dicotomia entre teoria e prática é um de seus pressupostos. Alguns desses tópicos já são discutidos na literatura; outros não são ainda mencionados e se restringem a pequenos círculos de grupos que buscam inovações. Trago-os como desafios prementes, que podem, e devem, provocar a quem quer construir a história, e não apenas ser um repetidor dela.

Restrinjo-me aqui a quatro pontos que delineio um tanto superficialmente, mas de maneira suficiente para que se possa instituir um debate a partir deles.

\section{A superação da dicotomia entre teoria e prática, entre o falar e o fazer.}

Inicio de propósito com esse ponto, pois julgo que seja ele o mais provocador e instigante no momento em que nos propormos discutir estratégias, políticas e implicações.

Creio que não seria ofender ninguém se disséssemos que é fácil notar, em muitas circunstâncias, tanto dentro da academia, como até mesmo em práticas assim ditas democráticas e populares, certa "burocratização da palavra", certa ênfase no retórico, onde a importância dada ao falar é preponderante, senão única. Tal prática, se bem examinada e criticada, mostra que é aí que se origina, ou pode se originar, uma separação entre o 
falar e o fazer. Como outras, esta é uma questão desafiadora e muito polêmica, que necessita ser aprofundada e discutida a fundo.

Gostaria de partir, nessa análise, de um texto de Paulo Freire, escrito no início da década de 70, que foi publicado apenas em algumas revistas, mas que circulou amplamente através de panfletos e folhetos. Trata-se de uma carta que ele escreveu a quatro jovens que estavam dispostos a assumir um ministério numa determinada confissão religiosa cristã. Parte, por isso, em sua análise, dos Evangelhos. Mas tudo o que o pedagogo fala sobre a prática que percebe nos Evangelhos, pode ser aplicada, analogamente, às práticas sociais, principalmente à prática educativa. Paulo Freire inicia dizendo que o que mais o fascinava, e ainda o fascina, nos Evangelhos, é a indivisibilidade entre seu conteúdo e o método com que Cristo os comunicava. Citando Freire:

O ensino de Cristo não era, nem poderia ser, o de alguém que, como muitos de nós, se julga possuidor da verdade e tenta impô-la, ou simplesmente transferi-la. Verdade Ele Mesmo, Verbo que se fez carne, História viva, sua pedagogia era a do testemunho de uma presença que contradizia, que denunciava e anunciava (Freire, 1987).

E ele continua dizendo que não se pode conhecer os Evangelhos se alguém os toma como palavras que simplesmente "aterrissam" em seu ser, como se ele fosse um espaço vazio, pretendendo enchê-1 O com elas. Essa seria a "melhor maneira de burocratizar a Palavra, de esvaziá-la, de negá-la, de roubar-lhe o dinamismo do eterno estar sendo, para transformá-la na expressão de um rito formal". Pelo contrário, diz ele, "alguém conhece os Evangelhos, bem ou mal, na medida em que, bem ou mal, os vive".

Está aqui o desafio central do texto. Não estaríamos longe da verdade se disséssemos que essa é uma revolução, ou reviravolta epistemológica. Até agora estávamos costumados a dizer que alguém pode conhecer algo simplesmente conhecendo... Lemos alguma coisa, escutamos alguém falar, e dizemos que conhecemos tal assunto, entendemos tal problemática. E agora chega alguém e nos diz que" conheço algo, se vivo tal situação". Como enfrentar tal questão, que não deixa de ser contraditória?

Pois é aqui que necessitamos parar e meditar. Pois, creio eu, há conhecimento e conhecimento. Nunca me esqueço do testemunho duma professora de psicologia que após quarenta dias de greve, expressou sua experiência de uma maneira profundamente realista e questionadora. Ela nunca tinha participado de greves. Eram já quarenta dias que em vez de aulas, se fazia reuniões; um dia com a Faculdade em que trabalhava, outro dia em assembléia geral de todas as Faculdades. E as negociações se prolongavam, entre idas e vindas. Nas assembléias discutiam-se as estratégias de enfrentamento, as diversas facetas presentes na confrontação de interesses antagônicos. Razões de uma parte e de outra eram apresentadas. As forças vivas presentes nos grupos mostravam-se aí claramente. Ela experienciava tal dinâmica contraditória momento a momento. Foi a partir dessa vivência que ela verbalizou, na assembléia, seu "conhecimento". Disse ela:

Agora eu sei (conheço) o que é greve. Greve é igual à masturbação (ela ensinava sexualidade). A gente fala, fala em masturbação para os jovens, e eles não entendem nada. Agora, quando eles têm a experiência, aí eles exclamam: 'Ah! É isso?' Pois assim também com a greve. Tinha ouvido falar tantas vezes... mas agora eu sei o que é uma greve!

O mínimo que podemos concluir disso é que existem conhecimentos diferenciados. Quem tem a experiência, isto é, quem pratica, possui um conhecimento diferente, com certeza. Mas é agora que se apresenta a questão mais importante: Que conhecimento possui quem só fala e não pratica? Imaginemos um professor(a) falando sobre cidadania, participação, política etc., mas que nunca participou em nenhuma prática social; mais, que até se absteve de participar, que não acredita em tais práticas, ou até as critica. Que tipo de prática possui ele? Certamente possui uma prática, pois é impossível não ter prática, como veremos mais adiante. Mas onde se coloca tal prática? Não seria uma prática alienada e alienante, conforme discutida por muitos analistas sociais, isto é, uma prática que só fica na palavra, no som que voa, que se resume e termina no puro sopro, e que não chega a se concretizar?

A questão que é posta aqui é a de que nós conhecemos diferenciadamente, alguma coisa, na medida em que vivemos, experienciamos e temos uma prática dessa realidade. No texto citado Freire vai ainda mais longe, afirmando que "conhecemos alguma coisa, enquanto buscamos praticá-la, e que essa é, assim, a melhor maneira que temos de ensiná-la". 
Esse seria o tripé de um educador: praticar para conhecer; e nessa prática que gera conhecimento, tem-se a garantia que se pode ensinar algo.

Cremos ser útil trazer à baila essa questão também por mais uma razão: são muitos os cientistas sociais que denunciam a existência de situações, dentro de um espírito de pósmodemidade, em que se percebe e se vive uma profunda incoerência entre o que é dito e o que é feito, ou vivido. A realidade se transforma numa sucessão de puros impulsos e fluxos, nada mais existindo além de um som que voa. As próprias palavras são esvaziadas e roubadas de seu sentido e/ou significado, transformando-se em meras virtualidades. Predomina o rito formal, vazio de sentido.

Arrisco uma consideração a mais: quais as consequências éticas de tais situações? O que parece originar-se, em casos semelhantes, é o perigo de certo burocratismo, muito próprio a instituições centralizadoras que se distanciaram, em suas práticas e ações concretas, do mundo da vida, e cujo valor central é o discurso, transformado numa verborragia que fica sendo sua prática dominante. Somente uma volta à prática, às ações concretas e vitais, poderá restituir sentido e conteúdo a tais ações. Muitas instituições (universidades, igrejas, parlamentos) podem se transformar em entidades vazias de sentido, onde o que passa a ter valor são unicamente as imagens que delas são produzidas, não contando mais sua prática concreta. A predominância da mídia, e de uma mídia em mãos de apenas alguns poucos grupos oligárquicos, é uma razão a mais que fundamenta e legitima a possibilidade de criação e reprodução de situações onde a fala passa a possuir uma hegemonia quase que absoluta.

Gostaria de acrescentar a essas considerações um ponto a mais, não necessariamente ligado, mas certamente relacionado, que é a discussão sobre o que é "ação", e a partir daí, mostrar que não existe uma prática neutra. Quem melhor discutiu isso, no meu entender, foi Israel (1972:123211), ao tentar mostrar que é impossível uma postura neutra em ciências sociais, isto é, que ser conservador, ou progressista, tem as mesmas implicações valorativas e uma dimensão moral. A argumentação de Israel baseia-se nas discussões que von Wright (1963a 1963b, 1968) estabelece sobre o que é "ação". Segundo ele "agir é causar ou impedir intencionalmente (por decisão própria) uma mudança no mundo (na natureza). Conforme essa definição, permitir (omitir) uma ação é tanto deixar algo como está ou permitir que algo aconteça. (von Wright, 1968:38). A partir dessa afirmação, Israel comenta:

A análise traz alguma luz sobre as consequências da atitude assumida pela maioria dos cientistas sociais tradicionais. Eles afirmam que sua posição com respeito à sociedade é neutra, e que a ciência social, em nome da neutralidade, não deve participar das ações sociais. Com outras palavras, bem ao contrário de sua afirmação de que eles não estão assumindo uma postura normativa, sua posição pode ser caracterizada pela norma de que não se deve de nenhum modo agir... o cientista não deve agir de modo algum. Consequentemente, não agir ou omitir-se é sua posição normativa. Mas, sendo que abster-se significa tanto 'deixar algo sem mudar', ou 'deixar que algo aconteça', os defensores desse tipo de ciência 'positivista' - quer queiram ou não - defendem o conservadorismo ou se tornam testemunhas passivas quando as coisas acontecem. Ser conservador é assumir uma posição definida em matérias de valor. Desse modo, a postura 'positivista', pelo fato de não ser isenta de valor, torna-se um 'boomerang', volta-se contra ela própria. Se, de outro lado, alguém 'deixa as coisas acontecer', ele se torna dispensável com respeito ao que acontece. Essa posição não é menos isenta de valor do que aquela assumida pelos que defendem uma 'ciência social emancipatória'. A última postura parece ser preferível dum ponto de vista moral. (ênfases nossas) (Israel, 1972:204).

\section{Pensando uma nova ética, para além da dialética.}

O tema da ética percorre, nos dias de hoje, todas as falas, em todos os momentos. Estamos, poder-se-la dizer, correndo atrás da ética. Isso faz sentido, pois a modemidade abandonou a ética, substituindo a ética pela razão instrumental. O cientificismo, a razão instrumental, na modernidade, se constituiu como um valor, mas paradoxalmente negando que fosse um valor, e declarando-se "neutra". A ciência não possuía valores, era neutra.

Acontece que há uma presença imprescindível da questão ética em todo agir humano. Não se pode pensar uma ação, sem que ela tenha uma dimensão ética. Como também não se pode pensar um fenômeno, sem que ele tenha uma conotação ética. Somente a partir daí serão possíveis novos avanços, creio eu, pois estará em jogo a própria pessoa humana. A questão da ética deve ser trazida para dentro da ciência. Durante quatro séculos não se discutiu a ética. Enfatizava-se apenas a dimensão ontológica (metafísica) 
e a dimensão epistemológica (teoria do conhecimento). Mas a ética, tão presente em qualquer fenômeno como a meta física e a epistemologia, ficou de fora. Na verdade, a ética nunca consegue ficar de fora. O que aconteceu, então, foi que a ética que se instalou foi uma ética especial, a ética da razão instrumental.

As consequências disso foram imensas. Zygmunt Bauman (1991), um filósofo polonês, discute isso em seu livro "Modernidade e Ambivalência", como também em outros, mostrando que o Holocausto foi, até certo ponto, uma consequência da ética da modernidade, a ética da razão instrumental, que entendia o mundo como um relógio, e que a única tarefa da ciência era descobrir as leis e as regularidades. Havia, implícita, a crença de que tudo está organizado, e que a ordem deve predominar em tudo. Ora, o diferente, o outro, vinha ferir essa ordem. Por isso deveria ser eliminado. E com isso se eliminaram todas "as ervas daninhas do jardim", os milhões de judeus, ciganos etc.

As reflexões, hoje, procuram dar conta dessa incorporação da ética nos trabalhos de investigação. Essa é certamente uma questão desafiadora, que agora começa a nos provocar e que necessita ser mais aprofundada. Parece arriscado dizer, mas talvez se pudesse sugerir o surgimento de uma nova lógica, que vai além das existentes, que alguns pensadores éticos denominam de "analética". As duas lógicas predominantes em nossos referenciais sempre foram a lógica da identidade (nada pode ser e não ser ao mesmo tempo, as coisas são "idênticas" em si mesmas, autoexplicativas), e uma outra lógica que desafia essa visão, mostrando que as coisas podem ser e não ser ao mesmo tempo, e que na sua própria constituição elas contêm sua contradição, que é a lógica da dialética. Acontece que nenhuma dessas lógicas incluía, como central, a dimensão ética. Pensadores novos, principalmente da América Latina (Enrique Dussel (1977a, 1977b), Manfredo de Oliveira (1996), ou ao menos do mundo sofredor e dos excluídos (Levinas, 1984, 1976), começaram a mostrar que seria necessário um novo paradigma, que em si incluísse o outro (dialética), mas o outro pensado de "um novo modo: não mais como "diferente" (di, que designa separação, e ferre, que significa conduzir, arrancar de), mas o outro pensado como "dis-tinto" (di, separação e tingere, que quer dizer pintar, bordar). O "outro" não seria o subordinado, o que só tem sentido a partir de mim, dominado e subordinado a mim; mas o outro seria o "outro" que me constrói na convivência. Essa lógica continuaria sempre dialética $\mathrm{i}_{\mathrm{i}}$ mas dando um salto além (ana, em grego, significa além, que transcende), incorporando a ética, como analética. Discutimos isso mais longamente em outra ocasião (Guareschi, 2000). Isso traz consequências também para a epistemologia. Novos temas poderiam aqui ser discutidos, temas ligados ao outro excluído, como a mulher, o estranho, a criança, o aidético, e principalmente o excluído político, que se torna o marginalizado econômica e politicamente.

\section{A redescoberta da comunidade}

Um terceiro tema que se nos apresenta hoje de maneira nova, provocando discussões e apresentando possíveis soluções aos diferentes problemas que nos afligem é o tema da comunidade. Essa questão da comunidade está intimamente ligada à questão do cotidiano (Heller, 1987), do Lebenswelt, da ação comunicativa, da racionalidade comunicativa (Habermas, 1989).

É minha percepção que o tema "comunidade" se constitui, hoje, num tema-chave, num tema gerador. A reflexão de grande número de filósofos éticos, nos anos recentes, acena para a comunidade, para o retorno ao cotidiano e importância de se viver plenamente o cotidiano, como uma possibilidade de solução de inúmeras "irracionalidades globais" (Santos, 1999).

A discussão sobre comunidade é, em última análise, a discussão sobre o cotidiano. O cotidiano é aquilo que tomamos como dato que não discutimos, no qual não pensamos. Há uma quantidade de fé que nós depositamos no cotidiano, que tomamos como pressuposto. Precisamos acreditar que a luz vai funcionar que o ônibus virá, que não haverá acidentes, que vou chegar ao serviço, que eu posso falar e que os outros vão me entender etc. O cotidiano estabelece para nós um colchão, como diz Jovchelovitch, sobre o qual todos nós podemos existir, dormir e descansar. Não só no nível das condições materiais que envolvem luz, transporte, mas principalmente na comunicação e na possibilidade de convívio social. Porque se, de repente, nós chegássemos a um lugar e nos déssemos conta de que todos os nossos códigos mudaram, não teríamos mais base para existir e viver. A grande tarefa da vida social, a fenomenologia da vida cotidiana, é providenciar essa segurança de que a vida continua, e que nós 
entendemos como ela continua. É interessante que nós não pensamos sobre isso. Pensar sobre isso é ser estrangeiro; é estar fora e olhar para um grupo social que é outro.

A comunidade é vista, hoje, como sendo uma possibilidade de vida mais plena sob vários aspectos. Certamente, ninguém pode dizer que consiga realizar-se em plenitude sem uma vivência comunitária. Vejamos alguns aspectos em que a comunidade poderia ser uma resposta na realização plena do ser humano.

Primeiramente no aspecto afetivo. Comunidade deve ser tomada como algo diferente de sociedade. Na sociedade colocamos em comum apenas funções, tarefas. Já na comunidade colocam-se em comum principalmente as relações primárias, de afeto e amizade. Em outros termos, na comunidade criam-se laços de solidariedade e empatia. Atribuise a Marx uma conceituação de comunidade muito significativa. Para ele comunidade é "um tipo de vida em sociedade onde todos são chamados pelo nome". É a superação tanto do individualismo, por um lado, como da massificação e do anonimato, por outro lado. Na comunidade todos têm voz e vez. Na comunidade é fundamental que as pessoas participem nas diversas decisões. Ninguém pode ficar esquecido, relegado ao segundo plano. As pessoas são vistas, tomadas em consideração, sentidas.

A comunidade está sendo vista hoje também como resposta na dimensão política. Talvez esse seja um dos pontos mais importantes e desafiadores. Há um convencimento geral que a democracia representativa, nos dias de hoje, está passando por profunda crise. Na democracia representativa escolhem-se pessoas para dirigir a sociedade de tempos a tempos, de quatro em quatro, ou cinco em cinco anos. Mas as pessoas votam e depois não sabem mais nada a respeito das pessoas que votaram. $\mathrm{O}$ número dos que sabem em que deputado federal, deputado estadual, ou em que vereador, votaram, não chega, no Brasil, a 20\%. Outra razão do desprestígio da democracia representativa se mostra no pequeno número dos que votam, onde o votar é livre. O prefeito do Texas, EEUU, elegeu-se com menos de $5 \%$ dos votos. Grande parte dos governantes que chegam a se eleger contam apenas com $20 \%$ dos votos da população. Como solução a esse problema, fala-se então em "democracia participativa". Essa seria uma prática política onde as pessoas são chamadas, ano a ano, momento a momento, a dizer sua opinião e expressar sua preferência sobre as 23 atividades públicas. Exemplo clássico disso é a prática do Orçamento Participativo, como já em funcionamento em muitos municípios, e agora começando nos Estados. O fundamental do Orçamento Participativo é o chamamento à comunidade para que venha dizer suas preferências e prioridades, para que se expresse sobre suas opções e seus projetos. E a comunidade que se torna o centro do poder político. Num juízo valor ativo sobre essa prática, pode-se dizer que ela recupera a plena democracia, relembrando os costumes dos antigos gregos, de quem herdamos as idéias de democracia e cidadania. Ao decidir sobre seus projetos, reuniam as pessoas na praça, na agorá, (infelizmente apenas os homens...). E só era considerado cidadão o que falasse, o que expressasse seu projeto, contribuindo, com isso, para a construção da cidade. Mesmo no pensamento social das igrejas históricas, a comunidade deve ser considerada como central, e nela devem realizar-se todas as atividades e decisões possíveis, deixando para um nível superior (município, estado-província ou nação), apenas o que não pudesse ser decidido e realizado na comunidade. Esse é o chamado princípio de subsidiariedade.

E comunidade está passando a se tornar resposta também, por incrível que pareça, na dimensão econômica, especificamente no campo do trabalho. Já foi o tempo em que uma carreira era construída a partir de uma boa educação no primeiro, segundo e terceiro grau, com alguma especialização. E depois se procurava emprego, um bom emprego certamente, passando a ganhar um bom salário, com carteira assinada. Com isso, é claro, se conseguia um bom casamento (sem excluir que se poderia descasar do mesmo modo). Aos poucos se poderia ter uma boa casa, ou apartamento, com um bom carro. Esse tipo de carreira (e de realização profissional) está praticamente terminando. De cada dez pessoas que conseguem emprego, apenas uma obedece ao processo descrito, isto é, com carteira assinada. As outras nove só conseguem empregos temporários, bicos, experiências, muitas fruto de trabalhos terceirizados. É o que se chama de flexibilização das relações de trabalho, que flexibiliza as máquinas, as empresas, as pessoas, o consumo, o próprio tempo. Nada mais é garantido de antemão. Esse o risco que corremos. E diante disso, o que vemos? Como se tenta dar conta dessa realidade, tão real, e tão dura? Pois vejam: mais e mais as pessoas vão se organizando em grupos, em comunidades. Um sozinho não consegue mais um trabalho, um emprego. Mas no momento em que se junta e se organiza com outros, eles vão 
conseguindo encontrar soluções, através de pequenas empresas, tipos diversificados de trabalhos cooperativados, atividades solidárias. Pode ser chocante para alguns, mas essa é a experiência do Movimento dos Sem Terra. Não fosse o trabalho e a luta solidária, em acampamentos, assentamentos etc., muitas milhares de famílias estariam hoje em dia vegetando, se não mortas, à beira de lagoas e represas, onde foram atiradas para dar lugar à construção de barragens; à beira das rodovias, expulsas dos latifúndios; e em locais em que vegetam ainda hoje, nos subúrbios e favelas das grandes cidades, em periferias inchadas por bairros pobres e ocupações irregulares. Eles compreenderam que se não se organizassem, não conseguiriam sobreviver. E estão dando conta muito bem do seu propósito. São milhares, senão milhões, de pessoas que numa época como a nossa, de alta taxa de desemprego e dificuldades de toda ordem, elas estão dando conta de procurarem e conseguirem um nível de vida digno através do trabalho na terra.

A comunidade está, pois, sendo vista com um novo olhar. Ela se constitui como uma superação tanto dum individualismo exacerbado, dum lado, que cria um capitalismo selvagem, e de um totalitarismo, ou dum coletivismo reificador, por outro lado, onde as pessoas não passam de peças de uma máquina.

Boaventura Santos chama a essas comunidades de "comunidades interpretativas". Em um texto seu ele comenta essa problemática afirmando que é necessário insistir nessas "mini-racionalidades". Dito por ele mesmo:

As mini-racionalidades não são racionalidades mínimas (...) se tivemos êxito em destruir os adamastores que existiam antes de nós, acabamos por criar outros adamastores ainda mais perigosos. Precisamente porque a racional idade moderna se aperfeiçoou, especializando-se, foi deixando nos interstícios da parcelízação uma irracionalidade global a que hoje, desesperadamente, procuramos dar nome: é a 'ditadura sobre as necessidades' de Agnes Heller (1987); a 'colonização do Lebenswelt (mundo da vida)' de Habermas (1987); a 'rigidez global' de Claus Offe (1987); a 'possibilidade global de um desastre eticamente inatribuível' de K.-O.Apel (1984). (...) A tarefa é agora a de, a partir dela (irracionalidade global), reconstruir um arquipélago de racionalidades locais, nem mínimas nem máximas, mas tão só adequadas às necessidades locais, quer existentes quer potenciais, e na medida em que elas forem democraticamente formuladas pelas comunidades interpretativas. As miniracionalidades pós-modernas estão, pois, conscientes dessa irracionalidade global, mas estão também conscientes que só a podem combater localmente. Quanto mais global for o problema, mais locais e mais multiplamente locais devem ser as soluções. Ao arquipélago destas soluções chamo eu de socialismo. São soluções movediças, radicais no seu localismo. Não interessa que sejam portáteis, ou mesmo soluções de bolso. Desde que expludam nos bolsos (Santos, 1996: 110-111)

É nisso que se está pensando quando se fala que hoje a questão é pensar globalmente e agir localmente.

\section{4. $O$ respeito aos diferentes saberes}

Esse último tópico é um desafio principalmente aos intelectuais e frequentadores de escolas e universidades. Trata-se de rediscutir determinadas visões que se têm hoje do que é ciência e do que seja conhecimento. Moscovici (1998), num de seus últimos estudos, discute essa questão, tentando mostrar a importância de uma reabilitação do saber popular, do saber do senso comum. Com relação ao saber popular, pode-se identificar duas posições bastante claras:

A primeira, que poderíamos chamar de a posição "científica", mostra desconfiança com respeito ao conhecimento espontâneo das pessoas comuns. Tais cientistas estão convencidos de que o conhecimento espontâneo deve ser purificado de suas irracionalidades ideológicas, religiosas e populares, e deve ser substituído pelo conhecimento" científico". Eles não acreditam que a difusão, a comunicação de conhecimento, seja algo que possa fazer crescer o nível de conhecimento público, isto é, do conhecimento popular, do pensar comum. Ao contrário, eles sempre acreditam que o pensamento científico, através da propaganda, no momento oportuno substituirá o pensamento comum.

A segunda posição é mais geral e poderia, talvez, ser denominada a posição do Iluminismo: o conhecimento científico dissipa a ignorância, fantasiada com os erros de um conhecimento não-científico, através da comunicação e da educação. Desse modo, seu objetivo é transformar as pessoas numa multidão de cientistas. Ao mesmo tempo, todos consideram a difusão do conhecimento científico como uma desvalorização, ou uma 
deformação, ou ambas as coisas, do conhecimento científico. Com outras palavras, quando a ciência se espalhar pela arena social, ela se transformará em algo poluído e degradado, porque as pessoas serão incapazes de assimilá-la. Podemos ver que há aqui uma convergência entre os dois pontos de vista: o conhecimento popular é perigoso e errado.

Diante de tais posturas, muitos cientistas sociais críticos reagem contra esta atitude e querem reabilitar o conhecimento popular que está fundamentado no nosso falar e na vida cotidiana. Talvez um pouco, além disso, ainda, esses cientistas sociais reagem contra a idéia subjacente que preocupou aos cientistas tradicionais durante longo tempo, isto é, contra a idéia de que as pessoas não pensam racionalmente, tendo criado teorias como o racismo e o nazismo. Mas Moscovici (1998, p.375) mostra o profundo engano de quem pensa assim: "Acreditem-me, a primeira violência antisemita teve lugar nas escolas e universidades, e não nas ruas".

Os cientistas sociais, hoje, tentam recuperar o valor do conhecimento popular, o valor do conhecimento do povo da rua, do povo simples. E se isso é assim no "mundo científico", muito mais o deve ser, dizemos nós, no "mundo social", isto é, no mundo político, econômico, religioso e cultural.

$\mathrm{Na}$ mesma linha de pensamento, Boaventura Santos afirma que a:

ciência moderna tornou possível uma ruptura epistemológica separando-se do senso comum existente... No entanto, uma vez realizada essa ruptura, o ato epistemológico mais importante é romper com ela e fazer com que o conhecimento científico se transforme num novo senso comum. É preciso, contra o saber, criar saberes e, contra os saberes, contra-saberes (Santos, 1996, p.104).

E de uma forma mais veemente ele afirma que:

há muitas formas de conhecimento, tantas quantas as práticas sociais que as geram e as sustentam (1996, p.328).

E logo após:

Não reconhecer estas formas de conhecimento (conhecimento alternativo, gerado por práticas sociais alternativas) implica deslegitimar as práticas sociais que as sustentam e, nesse sentido, promover a exclusão social... O genocídio que pontuou tantas vezes a expansão européia foi também um epistemicídio: eliminaram-se povos estranhos porque tinham formas de conhecimento estranho e eliminaram-se formas de conhecimento estranho porque eram sustentadas por práticas sociais e povos estranhos. O epistemicídio foi muito mais vasto que o genocídio, porque ocorreu sempre que se pretendeu subalternizar, subordinar, marginalizar, ou ilegalizar práticas e grupos sociais que podiam constituir uma ameaça à expansão capitalista... ou comunista (1996, p.328).

Gostaria de dizer, ao concluir, que os quatro pontos acima discutidos se constituem numa agenda altamente provocante, que parecem apontar, enquanto chego a perceber e sentir, para novos caminhos, ainda pouco trilhados, sem dúvida, mas extremamente pertinentes a uma Psicologia Social que se quer humanista, crítica, transformadora, compromissada com a justiça e a solidariedade. São luzes novas que deverão, certamente, estar presentes e até mesmo embasar nossas estratégias, nossas políticas e consequentes implicações.

\section{Referências Bibliográficas}

APEL, K-O. 1984, "The Situation of Humanity as an Ethical Problem". Praxis International, 4:250.

BAUMAN, Z. 1991, Modernity and Ambivalence. Cambridge: Polity Press.

CASTELLS, M. 1996, The Rise of the Network Society. Oxford, Blackwell Publishers.

CASTELLS, M. 1997, The Power of Identity. Oxford, Blackwell Publishers.

CASTELLS, M. 1998, End of Millenium. Oxford, Blackwell Publishers.

DUSSEL, E. 1997a, Acesso ao ponto de partida da ética - Para uma ética da Libertação Latino-Americana, vol. I. S.Paulo: Loyola/ Unimep.

DUSSEL, E. 1997b, Eticidde e Moralidade. Para uma Ética da Libertação Latino-Americana, vol. II, s.Paulo: Loyola/Unimep.

F ARR, R. 1999, Raízes da Moderna Psicologia Social. Petrópolis: Vozes.

FREIRE, P. 1987, "Palavração" Mundo Jovem, Ano 92, out. p.20.

GUARESCHI, P. 2000, "Sinais de um novo paradigma", in Freitas, R.H. e Guareschi, P. Paradigmas em Psicologia Social- a perspectiva LatinoAmericana. Petrópolis: Vozes. 
HABERMAS, J. 1987, Teoría de la Acción Comunicativa, Vol. I e II. Madrid: Taurus Humanidades.

HABERMAS, J. 1989, Consciência Moral e Agir Comunicativo. Rio de Janeiro, Tempo Brasileiro.

HELLER, A. 1987, "The Human Condition”, Thesis Eleven, 16:4. ISRAEL, J. 1972, Stipulations and Construction in the Social Sciences. In: Israel, J. and Tajfel, $H$. The Context of Social Psychology. London: Academic Press.

ISRAEL, J. e Tajfel, H. 1972, The Context of Social Psychology. London:Academic Press.

JAQUES, M.G. et al. 1995, Relações e Práticas Sociais. Porto Alegre: Abrapso-Sul.

LANE, S. 1981, O que é Psicologia Social. S.Paulo: Brasiliense. LANE, S. e Codo, W. 1984, O Homem em Movimento. S.Paulo, Cortez.

LÉVINAS, E. 1984, Totalité et Infini. Essai sur l'extériorité. Haia: Martinus Nijhoff Publishers, $4^{\mathrm{a}}$ ed.

LÉVINAS, E. 1976, Difficile liberté - Présences du judaismo. Albin Michel Ed., $3^{\mathrm{a}}$ ed.

MOSCOVICI, S. 1998, "Presenting Social Representations: A Convesation.” Culture \& Psychology, Vol 4 (3): 371-410.

OFFE, C. 1987, "The Utopia of the Zero-Option. Modernity and Modernization as Normative Political Criteria", Praxis Inernational, $7: 1$.

OLIVEIRA, M. 1996, Reviravolta Linguístico-Pragmática na filosofia contemporânea. S.Paulo: Loyola.

SANTOS, B.S. 1996, Pela Mão de Alice - O social e o político na pósmodernidade. Campinas, Cortez.

SILVEIRA, A. et al. 1999, Cidadania e Práticas Sociais. Porto Alegre: Abrapso-Sul.
THOMPSON, J.B. 1994, Ideology and Modern Culture - Critical Social Theory in the era of Mass Communication. Cambridge, Cambridge University Press.

THOMPSON, J.B. 1995, Media and Modernity- Toward a Theory of Social Communication.Cambridge, Cambridge University Press.

WRIGHT, G.H. von 1968, Na essay in deontic logic and the gemal theory of action. Acta Philosophica Fennica, Fase. XXI.

WRIGHT, G.H. von 1963a, Norm and action. Routledge \& Kegan Paul, London.

WRIGHT, G.H. von 1963b, The Varieties of Goodness. Routledge \& Kegan Paul, London.

ZANELlA, A. et al. 1997, Psicologia e Práticas Sociais. Porto Alegre: Abrapso-Sul. 


\section{Sociabilidade autoritária e abolição do castigo}

Edson Passetti

A Terra é azul!, declarou Yuri Gagarin ao dar a primeira volta ao redor do planeta. A Terra é a estrela azulada que se realiza no nada, emendou o poeta Caetano Veloso, ao descrevê-la, na prisão, por meio de fotografias, na canção "Terra". Nonada, palavra-invenção abre um dos mais instigantes livros escritos no século XX: o "Grande Sertão: veredas", de Guimarães Rosa. Minha obra se realiza no nada, conclui o filósofo alemão Max Stirner ao encerrar o desconcertante "O único e sua propriedade", escrito em 1844, e retirado imediatamente de circulação, pelas autoridades governamentais. Percurso estranho este que desloca nosso olhar da superfície para o espaço: não se olha mais para o céu imantado ao terreno pela gravidade. Olha-se para si de outro modo para reparar em coisas que a religião e a razão moderna irmanadas faziam crer ser o domínio do Homem.

Os organizadores desta sessão me pediram uma alocução para debate ao lado deste guerreiro que é o L. Escolhi falar de sociabilidade autoritária, nossa tradição cultural no interior do regime dos castigos e recompensas, nossa crença na autoridade central, no soberano, nas utopias e transcendentalidades. Não me dedicarei a uma detalhada exposição sobre as suas origens, mas, apenas, a uma resposta, a abolição do castigo.

\section{Autoridade}

Houve uma derradeira manifestação radical jovem, no final dos anos 70 do século XX. Os punks, diante do avassalador redimensionamento chamado neoliberalismo, bradaram: não há futuro!

$\mathrm{Na}$ década anterior, jovens dos mais diversos lugares do planeta externaram sua aversão ao regime da autoridade centralizada (família, instituições governamentais e de contestação, império do consumo, escolas, militarismo, modos e estandartizações de comportamentos). Enfrentavam o socialismo autoritário soviético na Europa oriental (enquanto, paradoxalmente, jovens chine,ses professavam sua fé no livro vermelho de Mao), o welfare-state na parte ocidental, o consumismo e o militarismo na América do Norte e, no Brasil, a ditadura militar. Eram práticas sociais ambíguas: umas se voltavam à libertação, outras à liberação. Algumas preferiam escolher um outro soberano, os demais nenhum soberano.

$\mathrm{O}$ anarquismo que tivera sua morte decretada, por políticos e historiadores, após o final da guerra civil espanhola, reaparece como algo menor, intenso. Ele rompe com a dualidade soberano-súditos. Traz consigo a grandiosidade do menor, reescrevendo a possibilidade de se ultrapassar a aspiração emancipatória que o envolveu no século XIX.

$\mathrm{O}$ anarquismo - $\mathrm{o}$ mais correto seria dizer anarquismos desestabilizava as certezas de socialistas partidários, liberais democratas, militares" policiais, intelectuais de gabinete, donas de casa e sexualidades. Ao mesmo tempo, se oxigenava com as contribuições de filósofos como Gilles Deleuze e Michel Foucault, entre outros, e redescobria a potência liberadora individual exposta por Max Stirner, na primeira metade do século XIX. Os anarquismos permaneciam na cena desestabilizando a base na qual se erguia a verdade milenar da soberania - Deus e razão - para afirmar uma nova política da verdade. Era um basta aos rebanhos democráticos e socialistas.

A reação a esta reentrada incisiva do menor, desarvorador de centralidades, veio de imediato. Nos anos 70, a política neoliberal buscando ativar a economia de mercado sustentada em Estados democráticos (como meta) ou ditatoriais (como meio), pretendia atingir o socialismo chinês, através da diplomacia capitaneada por Nixon e Kissinger, desestabilizando o equilíbrio de forças do socialismo em escala planetária; e, aproveitar estrategicamente dos efeitos das rebeldias dos anos 60 para investir no esfacelamento do império soviético, que dava sinais de queda para acabar em glasnost e perestroika, nos anos 80. Deslocava em definitivo o investimento produtivo para a conquista do espaço sideral, no qual, paradoxalmente, contava com a própria URSS. Não se investia mais diretamente no corpo humano produtivo, característica da sociedade, mas no corpo planeta.

Os punks respondem com a derradeira rebeldia do século resumida na palavra de ordem não há futuro! Expressavam a condição de filhos de desempregados que jamais seriam incorporados pelo capitalismo de mercado, pelas políticas de pleno emprego de inspiração keynesiana ou pelas compensadoras políticas sociais. Pelas ruas, estes seres cubistas 
desnorteavam a nova ordem, borrando com suas presenças a crença na democracia e no mercado Passaram a ser alvo da polícia. Eram o vírus no corpo social, análogo a outro vírus surgido no interior da liberação sexual chamado aids. A liberação estava novamente condenada à condição de peste. Em pouco tempo parte do movimento punk ampliou a penetração das práticas anarquistas em seu interior. $O$ anarquismo inaugurador de resistências socialistas à sociedade disciplinar atravessava e afirmava-se como uma nova política da verdade na sociedade de controle. O movimento anarco-punk, por sua vez, explicitava, entre outros, um efeito da passagem das formas de resistir da sociedade disciplinar para a de controle: os movimentos sociais como ficaram conhecidos desde o século XIX pareciam ter esgotado suas energias.

Na sociedade disciplinar dos séculos XIX e de boa parte do XX, a peste esteve associada às diversas verdades que procuravam contaminar $\mathrm{O}$ investimento do Estado no corpo são. Tratava-se de uma modelagem que o investia no corpo produtivo e exigia atenção de empresários e governos para ocupar exaustivamente suas energias corpo, evitando a emergência de rebeldias políticas (de onde saíram os socialismos). Os inimigos da sociedade eram identificados como indivíduos perigosos: pobres, operários, habitantes de periferias, delinquentes - contingentes ameaçadores da ordem universal capitalista fundada no direito.

No interior de uma sociedade pautada pelo exemplo, a disciplina e o exame, norteada por direitos e normas de produtividade amplamente vigiadas por especialistas, dentre os quais se inscreviam os criadores e reprodutores das ciências humanas, procurava-se obter adesões, por meio da persuasão. Tratava-se de uma forma na qual os súditos construíam a continuidade de sua condição de súditos, vendose a cada instante como possíveis soberanos (pai, médico, padre, chefe de sessão na fábrica, professor, marido, recriando métodos de conformação de comportamentos). Era uma época em que todos deviam ver a si próprios como sujeitos e objetos de investimentos, individualidades e totalidades agrupadas na mesma figura - a do sujeito - ainda que as verdades políticas digladiassem em nome do egoísmo individual e do altruísmo da espécie. Era o tempo propício à democracia, à ditadura, aos socialismos, em nome do Homem universal capaz de reconstruir sua existência desde a gênese mais longínqua. A descoberta da origem criava condições para projetos futuros grandiosos com a necessária disciplina, conduzidos por forças capazes de dirigir as vontades inconscientes. Era preciso expulsar do corpo do indivíduo e do social a periculosidade confinado-a a instituições asilares como prisões, manicômios e hospitais, na justa medida em que outras instituições garantiam a continuidade do corpo são como a escola, a família, o exército, a polícia, a fábrica. Era preciso o corpo útil economicamente e politicamente dócil.

Em nome dos direitos políticos ou dos direitos de igualdade, o Estado era o grande centro de investimentos. Do lado capitalista, pelo monopólio das armas, da educação, da saúde, da administração das pessoas, da moralidade religiosa, da difusão de direitos (civis, políticos e sociais), da propriedade privada e monopolista e, principalmente, do regime democrático. Do lado socialista, pelo monopólio das armas, da educação, da saúde, da administração das pessoas, da moralidade do partido único, da espera pelos direitos iguais, de economia estatizada e, principalmente, pelo regime ditatorial em nome do proletariado, levado a cabo pelo partido único. Qual seria a mais eficaz em produtividade? A história respondeu que diante da centralidade do poder no Estado com fluxos maiores ou menores de concentração econômica, era o capitalismo. Portanto, a peste deveria ser banida: por um fim a qualquer socialismo! Mas, neste ponto a sociedade disciplinar já não era mais a mesma. Ela cedia vez, sem desaparecer, a uma nova forma, que Gilles Deleuze, seguindo as sugestões de Foucault, chamou de sociedade de controle; diremos, uma sociedade capaz de redimensionar os dispositivos disciplinares diante do deslocamento do investimento do Estado no corpo são (uma biopolítica da população), para o corpo são para o Estado (uma ecopolítica planetária).

$\mathrm{Na}$ sociedade de controle o trabalho intelectual é priorizado. O investimento produtivo desloca-se da ocupação das energias mecânicas do corpo para o fluxo de inteligência a ser extraído de cada um. E uma forma de produzir com base na ocupação intensa e constante desta inteligência que se realiza pela simbiose entre o corpo e a máquina. São produções não mais orquestradas por indivíduos, mas articuladas por conjuntos de programas criados e recriados eletronicamente, por meio de protocolos confiáveis e governados pela diplomacia. Prevê-se e exige-se uma participação intensa e constante por parte de usuário dos programas que não cessa - como na mecânica -, quando o mesmo se desconecta do fluxo informacional 
produtivo propriamente dito. Muda-se de programação por meio de flexibilizações que levam, inclusive, para o lazer no interior dos fluxos computacionais e eletrônicos, analogamente ao seu deslocamento para demais fluxos de diversão, dentre os quais a televisão e o cinema se apresentam como novos produtores de verdades. No dizer de Cada Freccero, é a inversão do panóptico da sociedade disciplinar que a todos vigia. Todos se deslocam para a televisão, cinema e monitores de computadores para deles ocuparem-se de suas verdades.

O trabalho realizado não mais pelo corpo, mas por meio de intensos fluxos inteligentes faz variar o sentido da participação democrática pela qual cada um se vê decidindo sobre múltiplos assuntos (na empresa, na escola, na política, no interior do próprio conhecimento). Recomenda-se que todos sejam democratas, reiterando a ética da sociedade da transparência. Deleuze foi perspicaz em apontar para uma nova forma de resistir que aparece nesta sociedade informacional de controle. Uma nova forma de sabotagem aparece: não mais se atira o sabot (o tamanco na máquina para imobiliza-la, quebrá-la e expressar nossas resistências à ortopedia produtiva, da qual surgiram os sindicatos), mas um novo vírus de computadores - programas - para embaralhar dados, revirando controles sobre nós, não mais indivíduos sobre os quais se exercia uma determinada forma de vigilância e punição, mas, agora, divíduos, agrupados em banco de dados e outros localizadores precisos por meio de informações mínimas. Ficamos transparentes!

Não foi por menos que as primeiras investidas de resistências os fluxos de produção e vigilância eletrônicas (fábricas, escritórios, exércitos, serviços de segurança e saúde) foram designadas como atividades de cyberpunks. As resistências deixaram de compor campos de forças prioritariamente por meio de movimentos sociais. Nesse sentido, podemos dizer, que a palavra de ordem punk, não há futuro! foi redimensionada primeiro, pelo movimento anarco-punk, e depois, pelos denominados cyberpunks. Eles vieram para borrar a diplomacia e a democracia do produtivismo informacional. Contudo, não tardou à aparecer, como nas sociedades disciplinares, a criação de dispositivos localizadores destes hackers, novas formas de criminalização dos comportamentos ampliando o direito penal e, formas incorporadoras destes resistentes como novos agentes programadores ou de vigilância por empresas e Estados.
A população deixou de ser o alvo principal do Estado. Depois do efeito Hiroshima e Nagazaki, em 1945, - após o acerto diplomático do fim da II Guerra Mundial (a verdadeira revanche norte-americana contra o ataque japonês a Pearl Harbour, em 1941), o alvo passou a ser o planeta: recuperá-lo e integra-lo a novas conquistas espaciais, agora, siderais. A máquina de guerra dos Estados desloca-se da superfície do planeta para o espaço sideral. Mais do que lançar mísseis de ar e água e obter precisão sobre os alvos por meio de satélites, é preciso garantir a vida no planeta devastado: controle de águas potáveis, reservas florestais, preservação do ecos sistema, coisas que somente podem ser sustentadas pela difusão de direitos (para mulheres, crianças, etnias, homossexuais, deficientes físicos, ecologia, etc). Sabese que não se necessita mais do corpo enquanto gênero, sexo, idade ou etnia, mas fluxos inteligentes. Ser minoria com direitos passa a ser uma necessidade para corresponder a uma soberania que se desloca da territorialidade do Estado-nação para as uniões federadas centralizadas que devem evitar o risco do nomadismo - o que pode significar o fim do federalismo centralizado. É o investimento na positividade da migração, o que redimensiona a organização política se redefinindo enquanto territorialidade em aberto, criando condições para emergência do federalismo da União Européia, e aqui, abaixo do equador, o Mercosul. Na sociedade disciplinar os indivíduos eram localizados e, os direitos e a política estavam fundados em fronteiras territoriais demarcadas, para que houvesse a internacionalização das mercadorias. Na sociedade de controle os limites fronteiriços passam a ser limiares. Isto facilita migrações, diversifica direitos em outros universais e de minorias e, o internacionalismo cosmopolita de pessoas, agora corresponde à sideralização da economia. Mudanças à parte, são acertos em conjunto, programáticos, para fluxos de pessoas, mercadorias e políticas.

Permanece nesta ecopolítica uma sociabilidade escorada no regime do castigo e recompensa (da casa ao Estado, do Estado para Estado e da União para o Estado, e viceversa) pela difusão de direitos por meio da vulgarização da diplomacia política. Para a sociedade de controle não importa mais idade, força e lugar do corpo produtivo; ela exige jovialidade atualizada e saudável nos fluxos produtivos e, hedonismo modelar para o exterior, sua visibilidade no espaço público. Os monumentos, prédios públicos, rios, parques e museus são recuperados para revelar suas belezas originais a serem preservadas, depois do aluvião de detritos e dilapidações. 
Da mesma maneira, cirurgias plásticas, modelações corporais e recomendações de autoajuda, que apartam o privado do público, refazem exteriormente, a importância de cada um como alguém bem urdido que se apresenta, publicamente, como objeto restaurado de si.

Da disciplina ao controle, com mais ou menos democracia, poucos ou múltiplos direitos, sob diferentes formas de soberania, permaneceu intocável o regime do castigo como dispositivo educativo formador e reformador da disciplina e do controle. A sociabilidade autoritária progride pelo regime da dívida infinita de pessoas assujeitadas, convictas de sua servidão voluntária - como o jovem Etienne de la Boétie no século XVI na sociedade disciplinar, ou da servidão maquínica da atualidade, como sublinhou Gilles Deleuze.

\section{Liberdade}

A sociedade de controle, no início do século XXI, apresenta similitudes com a do final do XVIII em torno do que se convencionou chamar por despenalização. Naquela época, depois de se descobrir a prática produtiva entre os internos dos Hospitais Gerais europeus, em meio ao crescimento da população e da riqueza, abriram-se as portas destes HGs. Deles surgiu o hospital para doenças propriamente ditas, ao lado do atendimento domiciliar com vistas à higienização e internação da que a loucura como doença mental. Os reforma dores penais, dentre os quais encontravam-se Benthan e Beccaria, propunham o banimento, exclusão local, o trabalho forçado e a pena de Talião. Pretendiam punir e não vigiar numa sociedade de furtos e roubos que não era mais dominada pelos crimes de sangue e na qual as ilegalidades burguesas eram consideradas positivas. Decorre destes momentos a mudança de foco para a necessidade de segurança da sociedade tendo os pobres como alvos Anaturalização da aplicação do castigo como fator educador fará parte dos investimentos na defesa da sociedade com vistas a uma prevenção geral: a ameaça do castigo consagrada pela lei impessoal passa a ser mais eficiente do que o castigo público. Ele é pedagógico nas casas escudado pelo pátrio poder do direito civil, no cotidiano por meio de sanções regulamentadas pelo do direito penal e nas prisões como forma de investimento na recondução do cidadão faltoso. Delimita-se o crime como algo que atenta contra a sociedade e não contra indivíduos, sua vida ou bens.
No século XVIII, ainda, cabia à polícia, segundo Foucault, cuidar de uma nosopolítica, a assistência propriamente dita aos doentes. Era preciso preservar, manter e conservar trabalhadores como efeito da acumulação de pessoas. Prostitutas, adúlteras, crianças abandonadas, sifilíticos, pervertidos, pequenos trapaceiros, até então perigosos, foram colocados nas ruas e os prisioneiros levados para ofícios públicos e apresentados publicamente cumprindo suas penas. Ao lado da polícia da saúde (higiene) começa a tomar corpo a polícia força (contra os perigosos comuns e políticos). Não tardou para que no século seguinte, as prisões também incorporassem as técnicas da terapia produtiva ao lado da formação religiosa, como meios terapêuticos reintegradores do chamado delinquente à sociedade. Não era mais habitante da prisão aquele que cometia um ato infracional, sua vida passava a ser objeto de conhecimento da prisão. Ela passava a ser minuciosamente reconstruída como condicionante à infração e vinha a tona por meio do saber específico das ciências humanas (a psicologia e a assistência social) construindo a figura do delinquente.

o século XIX redimensionou a punição como vigilância, a ameaça do castigo por meio da intensa troca de saberes disciplinares e com a substituição do terror do suplício corporal público pela persuasão fundamentada na prevenção geral. A lei escrita e divulgada, os cantos de poetas e narradores criando memória favorável ao castigo de pais e mães, e o engrandecimento da pátria, formaram uma opinião pública favorável à prisão para aqueles que praticavam o rapto ou vi0lavam as sagradas liberdades consagradas pelas legislações civis, penais e constitucionais. Contudo, os reformadores deste século, também não tardarão em constatar que a prisão é incapaz de responder às especificidades dos crimes. Ela é nociva à sociedade; é cara e multiplica vícios; deixa os prisioneiros expostos às arbitrariedades de seus guardiões.

O importante para a sociedade disciplinar do século XIX era mostrar por meio da vigilância disciplinar a possibilidade do aperfeiçoamento da prevenção geral e o reconhecimento que se a prisão não educa, ela é a mais perfeita imagem do medo que apavora cada cidadão. É no seu interior, pela sucessão de penalidades cumpridas acompanhadas de novas infrações, que se gesta a história das torturas em torno da confissão, o agenciamento de trocas entre polícia e os delinquentes e o irremediável vínculo da família do prisioneiro com a economia das prisões. Diante de uma economia da pena 
regrada pelo direito que criminaliza e descriminaliza comportamentos segundo os momentos históricos - o que explicita não haver uma ontologia do crime - ergue-se uma economia de ilegalidaes e corrupções no interior da prisão transparente. Além dos altos custos materiais da prisão, constatase um alto custo social para o crime de vingança da justiça contra aqueles que se levantavam contra a liberdade limitada por direitos e aceita em nome da defesa da sociedade. Em lugar do despique de sangue, a vingança da justiça pelas leis impessoais. Desde então, ficou cada vez mais difícil abordar a relação entre castigo moral ou físico imposto a uma criança por seus pais escudados no regime do pátrio-poder e a prisão, local apenas existente como ameaça simbólica e jamais porto seguro para a reintegração social. A prisão ao não reduzir a criminalidade, apesar de todo o aparato de saber científico investido no prisioneiro, passa a ser um centro de confinamento para pessoas consideradas perigosas à sociedade. Neste sentido é que se encontra seu parentesco com o manicômio: uma confina o perigoso material, o outro o imaterial. São lugares para os que escaparam do que se espera na família, na escola, no trabalho, na política. São ladrões, assassinos, histéricas, rebeldes e revolucionários; não raramente tomados como parte de uma patologia que unifica a todos.

Não tardou para que no final do século XX, na sociedade de controle, com o neoliberalismo, aparecesse uma terceira versão para os perigosos a serem confinados. Eles não são mais os que precisam ser reeducados ou corpos a serem reintegrados. São apenas o que não interessam mais: escaparam de todos equipamentos de formação, destoam dos costumes, possuem baixo capital simbólico, provêm de famílias consideradas desestruturadas, são, enfim, pessoas para as quais o investimento social deve ser destinado ao ato de retirá-las em definitivo de circulação. Trata-se de uma reescritura da pena de morte, como exemplar forma desmesurada de prisão perpétua. Não há mais a pena de prisão perpétua no direito penal, mas um limite de anos a serem cumpridos. Contudo, abdica-se dos investimentos bio-psico-sociais ao preso, para dispô-lo ao jogo de forças físicas em tomo da iminência da morte. Isto se chama política de tolerância zero, a justa medida capaz de obstaculizar a possibilidade de volta ao convício social. É preciso tirar os perigosos de circulação em definitivo por meio de mais polícia e mais prisões.
O Estado de bem-estar-social cede lugar ao Estado penal. Pode parecer paradoxal, mas as novas prisões privatizadas (principalmente nos Estados Unidos) geram, simultaneamente, possibilidades para dinamizar a indústria da construção civil ocupando corpos desempregados na empreitada (nos termos das modulações pré-fabricadas e não do erguimento de muros e celas como no passado), seus possíveis futuros habitantes e à indústria eletrônica do controle do crime, como mostra Nils Christie, em A indústria do controle do crime, que constrói as prisões segundo os moldes da higiene e conforto, muitas vezes pleiteadas pelos defensores dos direitos humanos que permanecem encenando o espetáculo de denúncias que tanto fortalece o Estado, como salientou Foucault.

O controle eletrônico das infrações consideradas crimes - e qual de nós jamais cometeu uma infração? - acaba redimensionando a população nas cidades, principalmente nas metrópoles. As periferias passam a redesenhar outras formas para os campos de concentração. A difusão dos direitos vem afirmar o elogio à vida e cultura próprias da periferia, dormitório de trabalhadores empregados, camelôs, policiais e seguranças, intermediários do narcotráfico, pessoas que vivem de fora para dentro e cuja perspectiva é permanecer na própria periferia. Por meio de defesa de direitos exige maior segurança diante do crescimento da criminalidade associado ao narcotráfico e legitima políticas de tolerância zero. Pleiteiam urbanização das favelas, sistema de transportes, postos de saúde, e deslocam-se em direção a um revival da religião, fazendo crescer $o$ pentecostalismo e o catolicismo carismático.

Iniciam sua inserção nos fluxos produtivos eletrônicos como agentes de participação intensa, por meio das TVs abertas que funcionam como produtores de verdades. Elas ocupam o lugar que anteriormente cabia à escola. Organizam-se por meio de programas, também confiáveis, de auditórios, humorísticos, talk-shows, noticiários policiais, novelas e sitcoms atuando por meio da audiência e da participação direta na toma de decisões, introjetando as vantagens da democracia como voto, liberdade de opinião e juízo sobre o justo, combinando telefonia e computação. $O$ grande mobilizador permanece sendo a música vinculada à indústria midiática (cds, clips, musicais em TVs), articulando em feixes, as condições de habitação, higiene, saúde, segurança e ascensão social das pessoas que vivem nas periferias enquanto denúncias de condições sociais precárias e alegria de 
viver. A indústria da música (deixando-se de lado os iniciais programas downloads, via Internet) é, também, a forma mais rápida para se atingir o sucesso individual, num processo bastante acirrado, competitivo e de força, o smachmouth do individualismo exacerbado. Fica estabelecida uma continuidade entre os sonhos do cantor de rádio até televisão por meio da mesma indústria que diversifica aleatoriamente seus produtos efêmeros e a mesmice da vida na periferia, em tomo da saída individualista. $\mathrm{O}$ novo astro ou a nova garota do ritmo não são mais guindadas à vida de ilusões burguesas; o acesso aos bens de consumo tem um preço social: elas não devem atravessar os próprios cinturões das periferias.

A transformação da periferia em campos de concentração, leva também à difusão dos dispositivos de controle a distância, para o qual o regime de penas alternativas encontra um efetivo dispositivo de controle, na lucratividade tanto para a burocracia das ciências humanas com a vigilância de segurança (uma nova polícia, não mais de higiene e forças, mas também de administração do potencial a ser encarcerado, vivendo regimes de liberdade vigiada ou semiliberdade) quanto a indústria do controle do crime com o monitoramento de cada apenado. Ao mesmo tempo, no interior das prisões, aparecem os novos Estados como o PCC (Primeiro Comando da Capital), um outro soberano no interior do sistema prisional que negocia seus programas de cCRtinuidade das prisões, diplomaticamente com governos estaduais e federais, dando um basta à rebelião como forma de destruição das prisões. Restam apenas as unidades para jovens, ainda não infiltradas pelas organizações semelhantes ao PCC que de tempos em tempos ainda são destruídas pelos encarcerados.

Diante deste quadro, qual a importância do abolicionismo penal para jovens infratores? Do ponto de vista do Estatuto da Criança e do Adolescente, que aparece no início dos anos 90, após a institucionalização constitucional de 1988, redefinem-se as penas como medidas sócio educativas, dentre as quais destacam-se a liberdade assistida a semiliberdade e a internação para uma população que vive em situação de risco e, potencialmente, propensa a atos anti-sociais. Apesar da revisão da nomenclatura, trata-se ainda de um estatuto que se parametra pelo direito penal, definindu-o lugar para os perigosos (a prisão e a periferia), reescrevendo a prevenção geral. A questão central formulada pelo abolicionismo penal, a supressão do castigo, é ainda desacreditada em nome de uma possível reeducação destes delinquentes. Portanto, do ponto de vista da história das prisões, os encarceramentos para jovens ainda não foram atingidos pelo saber do Estado penalizador.

Uma breve reconstrução das formas jurídicas e sociais de governamentalidade, mostra que desde o Império, com os filhos de escravos, até a república, o Estado brasileiro atua tendo por alvo crianças e jovens pobres. Nesta fase, vamos do início do século XX com as internações agrícolas para filhos de imigrantes que perambulavam pelas ruas, identificados como vagabundos ou desocupados, até o surgimento das prisões para crianças e adolescentes potencialmente criminosas, como contemplou o Código de Menores de 1927 (não se esquecendo formas prévias desta institucionalização como a criação, em São Paulo, durante a década de 20, de uma ala especial para crianças loucas no Manicômio de Franco da Rocha), a caracterização das mesmas como vivendo em situação irregular (quando os migrantes nordestinos atingem os centros urbanos industrializados) pelo Código de Menores de 1978 (após mais de 14 anos da criação da Funabem pela ditadura militar, definindo a criança como problema de segurança nacional, para a qual além da escola se criaram diversos equipamentos de controle, instrução, recompensa psicológica para interiorização de normas e moral da disciplina, acompanhados de programas de recuperação de desnutrição para formar um futuro cidadão), para culminar no ECA, com o investimento no redirecionamento da conduta anti-social. Seja pela definição de situação irregular ou conduta anti-social, os dois institutos jurídicos apenas reescrevem a periculosidade exposta no primeiro código. Diferenciam-se métodos. Antes dos códigos prevalecera a internação agrícola, depois veio o reformatório, a seguir o investimento biopsico-social e, por fim, as medidas sócioeducativas. Em progresso, os saberes disciplinares da prisão se transformaram pelos programas da ditadura militar em interdisciplinares em torno da punição, oscilando entre a centralização (pré-90) e a descentralização (pós-ECA) administrativa. Entretanto, permaneceu a centralidade nas tomadas de decisão e o regime de defesa da fantasmagórica sociedade.

O abolicionismo penal propõe outra abordagem da infração desvinculando-a do direito penal para deslocá-la para o interior o direito civil, no qual não há a sequestro da palavra entre os opositores e, muito menos, a supressão da conciliação. Trata-se de abordar a infração como 
situaçãoproblema para a qual se exige o estudo de cada caso em especial distanciando-se de uma legislação penalizadora universalista. Se o ECA busca neste jovem forma-lo cidadão, o mesmo deve receber atenção especial tanto quanto a vítima (colocada pelo sistema penal na condição de testemunha de um processo contra alguém que feriu a sociedade). A tomada de decisão aceitável restringe-se à descentralização de poderes, evitando-se a preponderância de juizes, promotores, advogados e técnicos de formação humanitaristas (assistentes sociais, psicólogos, sociólogos e demais). Tratase de uma decisão consensual (incluindo os principais atores, vítima e infrator), segundo cada caso, decidida na localidade em que ocorreu o ato denunciado (não mais tendo por exclusividade a delegacia de polícia), envolvendo além dos protagonistas do sistema penal, pessoas próximas ao infrator e vítima.

O princípio conciliatório dimensiona a tomada de decisão tendo em vista respostas-percurso específicas para cada caso que podem desembocar, em compensação (na qual cabe ao Estado ressarcir a vítima quando o infrator não tiver posses para tal), terapia (jamais associada a internação em manicômios) e, principalmente em educação (com base no talento de cada um). Está em jogo uma decisão que abole a prisão para jovens, o castigo institucional ou a ameaça, por meio da invenção de repostas-percurso que não se esgotam em modelos, como afirmava Louk Hulsman e, muito menos em aceitação, ainda que provisória, de celas socialmente aceitas, como propõe Thomas Mathiesen, como passo intermediário para a abolição. $\mathrm{O}$ abolicionismo exige uma revisão conceitual que atinge o meio acadêmico, simultaneamente a uma predisposição dos envolvidos (a população para a qual se destina, em especial, o Código Penal/ECA). Mais do que isso, requer, segundo Hulsman, que cada um venha a abolir o castigo em si próprio, pois caso contrário, o máximo que podemos chegar é ao elogio às penas alterna tivas (por exemplo: trabalho forçado para a comunidade) como expressão pública do reconhecimento da eficácia do castigo que exige, por si só, uma vultuosa burocracia de controle direto e eletrônico.

O abolicionismo penal apresenta-se, desde o início dos anos 70, como uma nova política da verdade, possível de ser levada a cabo no Brasil para jovens infratores, desde que haja interesse em abolir simultaneamente a história da crueldade que se institucionalizou e que seja revisto se o cidadão que se pretende formar é mesmo aquele que se pela de medo da imagem da prisão. $\mathrm{O}$ abolicionismo penal não quer libertar a pessoa do crime, mas sim, liberar talentos e centralidades de poder. Inscreve-se, pois, como fluxos de resistências múltiplas, linha de fuga necessárias a quem se interesse por liberdade enquanto potência e não normalização. $O$ abolicionismo penal não é uma forma de decreto diante da supressão do castigo. Ele em si mesmo é uma reposta-percurso no sentido da abolição de um castigo entranhado na pessoa pelos costumes. Ele se introduz no fluxo da ordem como um vacúolo, no dizer de Deleuze, mais um atualizador das virtualidades libertárias.

Devemos estar atentos para o fato da sociabilidade autoritária, fundada na centralidade de poder em rede que nos formou ter gerado um círculo viciado no qual se adentra no regime dos castigos exposto à força de um superior iminente, o que reduz os regimes políticos a invariâncias. A criança encontra-se à disposição do uso da força moderada dos pais regulamentada pelo Direito Penal (maus-tratos) e à força incomensurável do medo, de maneira análoga à que a mulher se relaciona com o marido e este aos seus superiores no fluxo da produtividade. O abolicionismo penal está interessado não em libertar um do outro dando margem ao surgimento de um novo soberano. Está interessado em como se dá a continuidade da condição de súditos entre os súditos rompendo o circuito punir, vigiar, controlar, a identidade entre educar e instruir, a verdpde da maioridade seja ela do cidadão, do Estado ou do mercado. O abolicionismo penal, estrategicamente não se pretende maior, mas apenas mostrar a intensidade de sua menoridade. Ele não é uma utopia, um consob para o futuro, mas um devir criança como heterotopia. Pretende apenas mostrar que menor não é sinônimo de minoria, de quantidade, ou lugar de direito difuso.

Nossa cultura herdou o platonismo que atingiu modemamente a razão pela afirmação da maioridade da razão exposta por Kant que em termos políticos nos remete a uma futura situação utópica de paz perpétua entre Estados federalizados e organizados segundo o prinópio da centralidade, com base nos direitos políticos, dos povos e no cosmopolitismo fundado no comércio livre, com a supressão dos exércitos obrigatórios. Desta maioridade contra o domínio da religião, diversas atualizações ocorreram. Em Hegel traduzida pela possibilidade da interpretação das forças inconscientes por parte do soberano único; em Marx pela emancipação 
humana que por meio do partido da revolução que interpreta corretamente o sentido das forças instituindo o socialismo do século XX.

Outras produções de verdades adversas ao castigo e à maioridade se firmaram, desde Heráclito e sua leitura desterritorializante da vida. Poderíamos lembrar da sinceridade dos cínicos, dos epicuristas alheios à política construindoseu mundo a parte, dos estóicos com seus cuidados de si, mas atentos à política. Estas referências menores foram revigoradas na modemidade por La Boétie e pelos anarquistas. Não há maior sem o menor (adulto/criança, saúde/doença, discurso/práticas não-discursivas), contudo não se pode dizer que todo menor se pretende maior (segundo Stiner, o nosso grande desafio é pensar criança diante de um mundc pe pensares adultos povoados pelas fantasmagorias religiasos e racionais). Devo dizer, apenas, que a busca pela potência de liberdade é afirmativa (não pleiteia ser soberana, mas horizontal e alheia à construção do melhor soberano).

No final do século XVIII, na Inglaterra, Willian Godwin, em Political justice, já mostrava o castigo como marca da sociabilidade autoritária moderna, reafirmando o soberano da casa ao Estado por meio de uma educação com base na punição. Defendia o autor uma sociedade sem castigo, por meio de uma educação livre do Estado com base notalento das crianças compartilhado pelas pessoas à sua volta o que supunha também, o fim do casamento monogâmico, substituído por relações amorosas livres, numa organização da vida livre desvinculada de autoridade centralizada, de hierarquias. Estava exposta, modernamente, pela primeira vez, a possibilidade de práticas sociais capazes de abolir os castigos e as guerras. Estava, também, anunciada a periculosidade no pensamento.

O abolicionismo penal é apenas uma parte desta vontade de potência, atualizadora das virtualidades que sempre existiram em nossos costumes; é uma realidade diante da acusação de ser uma utopia. Ele busca eco, iguais diferentes, livres do universalismo, que sabem que a continuidade da punição se afirma pela crença na necessidade de se impingir sofrimento ao outro. Ele investe em crianças e jovens como possibilidades de liberdades.

A vida caminha para a potencialização da penalização com a formação do Estado penal, das políticas de tolerância zero, a conformação das periferias como novos campos de concentração e o apelo ensandecido da população por mais segurança. O círculo da sociabilidade autoritária (nossa maioridade) se torna cada vez mais efetivo e transparente, ao mesmo tempo em que vacúolos libertários (nossa menoridade) nele se inserem. Trata-se de uma escolha. Os autoritários preferem adultos, Estado e prisões. Eu prefiro crianças, pensar sem fantasmas e liberdade. 


\section{Cultura Brasileira - diagnóstico do presente ${ }^{1}$}

José Paulo Bisol

A minha saudação ao Francisco Ritter. Minha alegria de estar aqui ao lado do Edson Passetti. A vontade que eu tenho é de entregar a Secretaria de Segurança para o Edson. Meus demônios, ao ouvir o Edson, simplesmente seduzidos, encantados, eu estou completamente de acordo com o que ele disse. Acho até que ele devia, em vez de me ouvir, devia pensar o que ele disse e ver até onde nós encontramos aí! Mas os meus demônios também me disseram assim:

Vocês são psicólogas/os. O que significa isso? Vocês querem salvar almas? E o logos da alma, a razão da alma? Para falar a verdade eu, quando cheguei em Santa Maria, e nem sabia que existia ainda, eu me dei conta que era um ser aqui em Santa Maria! A primeira coisa que eu desejei ser foi padre. Porque é muito melhor salvar a morte do que salvar a vida. É muito mais fácil e muito mais sedutor. Imagina aqui se eu fosse um padre.

Vou contar a história do monge Botsatwa que queria chegar ao Nirvana. Foi tendo sucessivas iluminações; na primeira conseguiu livrar-se da sensualidade; na segunda, das raivas e paixões terrenas, até que ele conseguiu livrar-se do egoísmo. Ao elevar-se, na última iluminação, Botsatwa estava pronto para ir ao Nirvana. Mas aí ele pensou: Se eu for sozinho, deixarei todos os outros sofrendo aqui na Terra. Como ele já havia superado o egoísmo, Botsatwa decidiu ficar até que todos os seus irmãos e irmãs pudessem ir com ele.

Vamos discutindo, procurando pensar o que é cultura, o que a cultura faz comigo, o que ela faz com você. Você existe, você existe como você, você tem uma identidade, você é um sujeito. Mas até onde você é um sujeito? Antigamente, até eu nos meus 20, 25, 30 anos fiz um discurso: "Vamos, povo brasileiro, ser sujeito da nossa história!" Não conseguimos ser os sujeitos da própria biografia, desgraçadinha, pequeninha! Até onde você, que está me ouvindo aí, é um sujeito? O Deleuze foi umas três ou quatro vezes citado aqui; também o Guattari (que escreveu com ele dois dos

${ }^{1}$ Este texto é uma transcrição direta da participação do autor na mesa redonda. Em função de falhas técnicas no registro, foi necessária uma revisão onde se refez a fluência e clareza do texto sem interferir no conteúdo ou nas idéias expressas pelo palestrante. 47 livros), o Foucault, todos eles foram citados aqui pelo Edson. Qual é a insistência básica deles? É que o sujeito é uma figura que se diluiu. Eles dizem assim: "Olha, meus queridos psicólogos, vocês são objetos de uma subjetivação. Existem forças aí... que fazem com que você até tenha uma sensação de ser sujeito, mas essas forças são sujeitos de sua própria identidade, isto é, você não tem uma identidade".

E aí até a sociologia moderna já desistiu da identidade, ela fala de um processo dramático, um esforço dramático, em que a gente trata de uma identificação para não se diluir completamente. Dia-a-dia, minuto-a-minuto eu tenho que me cuidar, porque se não eu me diluo no nada. Pode ser um nada azulado, como foi dito na palestra anterior. Mas me diluo no nada, quer dizer que eu não sou um sujeito, eu não tenho uma identidade; eu sou só um esforço dramático, trágico, para não me diluir completamente e ser. Mas ser como um sentido, e aí eu volto a citar o Deleuze. O que é o sentido? É um deslizamento nas proposições - eu acho que a expressão dele é essa - se a minha memória não falha. Nada mais que um deslizamento. A minha identidade, a sua, não são nada mais do que deslizamentos. Mas, gente, eu não sou um inimigo da vida e nem sou um inimigo de você, com essa cara linda me olhando! A vida vale a pena, mas vale a pena nesses termos, de um esforço de sentido.

Tanta gente não ter chegado ainda a perceber que não existe outra alternativa de felicidade se não essa... que, de repente, a gente está se esforçando, honestamente, para termos sentido singular com os outros, porque não há singularidade sem o testemunho da alteridade. Sem o outro nada existe, ninguém existe. Então, gente, vocês me trazem aqui para falar de uma cultura justamente no momento em que eu sou secretário de segurança e secretário de segurança é anticultural no sentido generoso da palavra cultura! Então eu imagino assim: vocês são psicólogos - e principalmente as moças são lindas - eu ficaria aqui extasiado, sem dizer uma palavra e isso seria o suficiente para me sentir feliz, só olhando para vocês.

Mas, e se fossem os brigadianos que estivessem aqui? Se fosse a polícia militar, se fosse a polícia civil que estivesse aqui? Ainda não falamos na polícia. $\mathrm{O}$ maior e o mais obscuro dos poderes institucionais. Polícia: ninguém cuida dela. Ninguém quer discuti-la. É uma das coisas mais cavernosas, mais opacas, mais impenetráveis de toda a institucionalidade, não só do Brasil; do mundo, gente. Existe uma polícia 
em um país melhor do que outra polícia de outro país, mas não existe nenhuma polícia realmente boa.

Essa é uma questão importante? Nós chegamos a pensar isso? O que significa esse fluxo inteligente que estivemos discutindo na palestra anterior? Isso sim: eu, para ser inteligente, eu tenho que ser pensado, eu não tenho de pensar. Dentro desse fluxo de inteligência, eu não sou quem pensa, eu sou quem é pensadu. Desde que eu sou secretário de segurança, eu estou vivendo uma experiência de ser pensado, de ser objetivado, de ser sujeitado.

É incrível, incrível. Eu digo o que eu não disse jamais; eu faço o que eu não fiz jamais. Acontecem em tomo de mim fantasias reais, e todo mundo fica se pronunciando sobre essa fantasia como se ela fosse real. Eu estou sendo empolgado pelo fluxo de inteligência.

Vocês estão vendo que na mídia estão falando em PM2. Aí vão ouvir um deputado, deputado do meu partido, e ele fala sério da PM2! Aí vem um outro e fala sobre PM-2. Então, a PM-2 fica como alguma coisa da Secretaria de Segurança. Então, eu sou o sujeito da PM-2; e eu sou a maior vítima da PM-2! Eu não entendo mais nada! Ou está todo mundo na fantasia ou eu estou na fantasia! Ou eu estou no mundo real, quer dizer, a PM-2 é um negócio secreto, não institucional no sentido de Estado. Ou então ela é uma droga, uma insignificância. Ela é algo importante porque é secreta. Ela é algo forte porque ela é não-institucional no sentido de Estado, de instituição estatal. E ela é inimiga de quem? Inimiga dos justos, inimiga dos que buscam a singularidade, dos que lutam para, ainda que seja deslizando nas proposições, ter um sentido. A realidade social, então, é o oposto da realidade em que eu vivo. Eu sou, na minha opinião, o maior inimigo da PM-2; mas na mídia, e consequentemente na opinião pública do Rio Grande do Sul, eu sou o sujeito controlador da PM-2. Vocês estão percebendo o que eu quero dizer agora, dando um sentido específico ao conceito genérico colocado pelo Edson, o fluxo de inteligência, o que ele faz comigo.

Hoje a Sociologia e a Psicologia Social, têm uma dimensão de conhecimento que eu acho que eles chamam de teoria dos efeitos perversos, não é assim? Ou teoria das consequências paradoxais, que é aquela velha coisa do Popper e do Hayek, veja que eu não cito só os de esquerda, nem só os malucos. Eu cito também os velhos burgueses, assentados, o Hayek, o
Popper. Então, o que é que o Popper dizia com muita razão? "Nós, até hoje, descrevemos a história como se ela fosse atos de vontade individuais que, através da mediação de ações, tivessem produzido as consequências desejadas". Quando isso raramente acontece e, quando acontece, é fora da dimensão histórica!

Entenderam o quero eu dizer? Não adianta você e eu sabermos a verdade, se o que é vivido como verdade pela comunidade é outra coisa. Então, a nossa verdade é uma mentira, a realidade é uma mentira. A verdade é que eu, sem saber, sou o sujeito controlador da PM- 2. E tem mais, gente. Eu vou pegar essas coisas da minha vida cotidiana para vocês, psicólogos, que têm que lidar com as almas cotidianas, as suas impotências, os seus excessos, as suas esquizas, suas escisões egóicas etc. É com isso que vocês vão ter que lidar.

O Rio Grande do Sul, como comunidade, acredita que José Paulo Bisol e o MST combinam as coisas que o MST vai fazer. Esse secretário de segurança, secretamente, é um gênio. Eu não sabia e sou um gênio! Eu combino com o MST para tomar os prédios do Governo Federal. Aí, eu já digo para eles: "Olha, vocês levem foice, levem piche..., e o resto deixem comigo!" Gente, essa aí é a "realidade", é o que é falado. É o que a mídia pensa no Rio Grande do Sul. É o que a Zero Hora pensa, é o que a RBS pensa. Mas eu preciso ser muito estúpido para assumir a secretaria de segurança e ir lá conversar com o MST. Eu sempre disse, francamente, que sou a favor deles, considero o movimento social mais bonito, mais evangélico da nossa história. Sempre disse isso, em qualquer lugar que me perguntassem. Mas eu não sou uma besta quadrada para ir lá e articular com eles a tomada do Chocolatão! Mas então, essa é a "realidade". Eu combino com eles para tomar o Chocolatão. Ora, te coloca no meu lugar, companheiro; vai ser secretário de segurança... ! (Olhando para o colega de mesa, palestrante anterior, Edson Passeti).

A sociedade do Rio Grande do Sul acha que eu combinei com os guris - até aqui em Santa Maria ouvi isso para ir lá queimar o relógio. Eu ouvi isso. Eu, com a alma, queimei mil vezes. Eu e a Marilena Chauí. Queimamos horrores de vezes e queimaremos ainda até morrer. Mas, eu não sou um imbecil! Já pensou fazer uma coisa dessas? 
O que é verdade, o que é real? Entende o que eu quero dizer, o que é subjetivação? Que processo é esse que cria um sujeito a despeito devocês, e cria esse sujeito através de vocês? Que monstro é esse? É aqui a coisa delicada. O que adianta eu percorrer cinco anos como universitário de psicologia, se eu não me dou conta de que a vida social está sempre virada ao avesso! Quer dizer, sempre, e reparem bem, eu não estou sendo levado por um impulso, eu estou afirmando: sempre a mentira funciona como verdade. A verdade pobre, frágil, nem sempre bem definida, bem determinada, coitadinha, a verdade é assim mesmo... Essa, tem dificuldade. Você acha que está pensando quando você pensa que eu combino com o MST, que eu combino com os guris de Santa Maria: “ó, vocês lá, eu dou um jeito e vocês queimam aquele relógio dos 500 anos". Olha, eu não aguento mais... Eu sabia disso porque eu sou um velho leitor do Foucault, eu sou um companheiro - de leitura, é claro, eu sou um ignorante perto dele - do Guattari, do Deleuze, dessa turma. Eu procurei saber. Mas gente, a força, a brutalidade dessa produção de subjetividade..., estou empregando a expressão do Guattari e do Deleuze.

Eles produzem uma subjetividade em que a sua singularidade desaparece, a minha desaparece, tudo desaparece, o valor desaparece, a dignidade desaparece, a felicidade desaparece, a diferença desaparece, tudo o que é bom na vida desaparece. Cada vez mais esse "Hampt-dumpt" vocês se lembram quando eu estive aqui em Santa Maria e eu contei a história do "Hampt-dumpt", personagem do Lewis Carrol em "Alice no país das maravilhas"?

\section{Público - Não!!!}

Não, mas estão lembrados sim. Como? Que memória?

Olha, vocês psicólogos têm que fazer a análise do "Hampt-dumpt"! O Deleuze faz, naquele livro dele sobre o sentido... Os primeiros capítulos são sobre o Lewis Carrol, como uma esquizofrenia de superfície. Depois, mais adiante, ele relaciona o Lewis Carrol como um ator, um genial - ator, como esquizofreniade profundidade. Não sei se a minha memória está me traindo. Esse é o livro do Deleuze sobre o sentido, "A lógica do sentido". Vocês então, têm que examinar psicologicamente, psicanaliticamente, esquizoanalicamente (fazer a esquizoanálise) do "Hamptdumpt". Não há livro de semântica que não cite o "Hamptdumpt", que é aquele personagem do Lewis Carrol, que é considerado o homem-ovo, porque é barrigudinho, é redondo, e que tem um diálogo com a Alice mais ou menos nestes termos:

Hampt-dumpt - Eu, Alice, quando digo uma palavra, dou a essa palavra o sentido que eu quero dar.

Aí vem a Alice (vocês..., os puros de coração...) - Mas, Hamptdumpt, a questão não é essa. A questão é saber se a gente pode dar o sentido que a gente quer para a palavra.

Hampt-dumpt - Alice, deixa de ser boba lá... A questão é saber quem é o servo e quem é o senhor, porque o senhor, é senhor da palavra: ele fala, o servo escuta.

Essa é a simbologia, pelo menos neste momento, que eu quero dar a esse personagem, o "Hampt-dumpt". Ele é a opinião pública da modemidade! É a mídia da modernidade. Eu dou, não só a qualquer palavra, mas sim, a qualquer fato, o sentido que eu quero dar!

E aí, o Bisolzinho, de manhãzinha, está dormindo, e tem um despertador no bidê. Na hora em que ele precisa acordar, acende uma luzinha no despertador, e vem uma voz... e vem uma voz das origens, e vem uma voz da tradição, voz da revelação, voz da verdade, e diz. O Bisolzinho está recém no estado entre adormecido e acordado. Aí a voz diz assim: "Os fatos que aconteceram nas últimas 24 horas são A, B, C”. E o Bisolzinho começa a acordar! "Puxa, A, B e C..." Ele respira fundo...

Daí vem outra voz, ou a mesma, mas também vem das origens, também vem da indiscutibilidade, também vem da revelação divina, também vem da Bíblia, e diz assim: "O sentido do fato A é A', está me ouvindo? Do fato B é B'. Do fato C é C', e acabou." Em seguida o Bisolzinho acorda e vai tomar o seu banho. Sai do banho, abre o jornal, e lá está o fato A, o fato B e o fato C. No editorial está o sentido A', B' e C'. Então, gente, o Bisolzinho vai trabalhar e descobre que existe a comunidade universal! Existe a comunidade universal, por que todo mundo sabe que os fatos importantes são $\mathrm{A}, \mathrm{B}, \mathrm{C}$ e todo mundo concorda que os sentidos são $A^{\prime}, B^{\prime}, C^{\prime}$.

Ou seja, a comunidade, coitado de Marx que se despedaçou atrás dela! Veja, a comunidade que está aí na hora do trabalho; todo mundo discutindo o mesmo fato e tendo as mesmas idéias. Isso aí é a produção do 
sujeito, é a produção da subjetividade, e eu estou afogado nisto, não aguento mais. Vocês entenderam o que eu quero dizer?

Agora vocês vejam aqui... esse cara aqui (mostra o livro), é o Guattari, que escreveu dois dos livros com o Deleuze, dos mais importantes por sinal. Olha aqui (lendo no livro): "A palavra cultura tem vários sentidos no decorrer da história. Seu sentido mais antigo é o através da expressão" cultivar o espírito". (O Voltaire é que dizia, né, "cultive o seu espírito") "Vou designála, diz ainda o Guattari, sentido A, ou sentido de cultura-valor".

Quer dizer, você é um homem culto, Guareschi (aponta Pedrinho na platéia). Você é uma maravilha, você cultivou o espírito, você sabe tudo. Você, o Edson e o Bisol citam o Deleuze, citam sei lá mais quem, vocês são o máximo. Essa é a cultura do sentido A. Corresponder ao julgamento de valor que determina quem tem cultura; alguns têm, os outros não têm, coitados. É uma segregação maravilhosa... Nós estamos por cima! Pelo menos nisso...

Bem, diz ainda o Guattari, "O segundo núcleo semântico da palavra cultura agrupa outras significações. Vou designar o sentido B: é a cultura alma coletiva". É aquilo que o brasileiro imbecil sente quando nós não ganhamos nenhuma medalha de ouro nas olimpíadas. Vocês leram o Luís Fernando Veríssimo hoje? A Dinamarca ganhou menos medalhas do que o Brasil... Mas é uma das melhores sociedades do mundo, gente. O que nós queremos, ganhar medalha ou chegar a uma sociedade boa, como começa a ser a sociedade dinamarquesa, uma sociedade que tende à justiça, que permite a singularização, que estimula a singularização, e que não deixa ninguém de fora da possibilidade da singularização. Porque a singularização, no sentido A de cultura, é muito bonito, mas deixa milhões de pessoas fora dessa possibilidade!

Então, vamos entender alguma coisa com o Guattari, sobre o segundo núcleo semântico, o B. "A cultura seletiva é sinônimo da civilização. Desta vez, já não há mais o ter ou não ter cultura, todo mundo tem cultura e esta é uma cultura muito democrática, qualquer um pode reivindicar sua identidade cultural. É uma espécie de a priori da cultura." Fala-se em cultura negra, cultura underground, cultura étnica e assim por diante. Quantas culturas vocês conhecem? Até eu fiz um discurso "precisamos transformar a cultura policial". Continuando com o Guattari: "Há uma espécie de alma um tanto vaga, difícil de captar e que se prestou no curso da história (aqui é que está o negócio!) a toda espécie de ambiguidade, pois é uma dimensão semântica que se encontra tanto no Hitler, quanto no maior democrata do mundo". Isso aí serve para tudo, esse tipo de conceito serve para tudo, gente! Por isso que, em outra parte, o Guattari diz, e o Deleuze também diz isso, "não existe nada mais reacionário do que cultura".

O que é cultura? O que a brigada me diz? O que a polícia civil me diz? "Vamos preservar a cultura. Você quer destruir a nossa identidade. Você que desmontar o nosso sentido." O que é esse negócio de cultura, afinal?

E o terceiro núcleo semântico, o $\mathrm{C}$, é nesse que nós precisamos chegar! Ele designa... , já é o Guattari falando, "o C corresponde à cultura de massa, e eu o chamaria de culturamercadoria". Essa é a que você vive! Ela tem que ter é a servidão da escuta, porque o "Hampt-dumpt" é o senhor, porque tem a palavra. E você escuta, com todo o seu curso de psicologia. Aí já não há julgamento de valor, nem territórios coletivos da cultura, mais ou menos secretos, como nos sentidos A e B; a cultura são todos os bens, todos os equipamentos, todas as pessoas, isso tudo o que você vive aí, filme, teatro, política, tudo... Essa cultura de massa, diz o Guattari em outra parte, "é o elemento fundamental da produção de subjetividade capitalística."

$\mathrm{O}$ que eu estou querendo dizer para vocês - sou velho, não preciso mais encantar ninguém, nem seduzir... já é um trabalho enorme seduzir a mim mesmo, posso dizer tranquilamente: é o que consome vocês, é o que mata, é o que fecha todas as possibilidades de liberdade, é o que nega a dignidade e a alegria de estar no mundo e ter um sentido, ainda que escorregadio. É o que iguala, e não adianta você ter um nariz, uma boca diferente; você é igual aos outros, cada vez mais igual, cada vez mais arrastado pelo que não é real, e eles dizem que é.

Não há quem não beba Coca-Cola, foi bem empregado aqui. Nós bebemos Coca-Cola por imbecilidade! Por produção capitalística da subjetividades do gosto. Nós nem temos relações sexuais originalmente mais. Nós podemos transar em público que todo mundo faz igual. Ninguém tem mais talento, singularidade, diferença!

Então eu vim dizer isso para vocês. Esse fim de século, nós atingimos nesse tipo de paradigma. E a pior fase da humanidade; desse ponto de vista da singularidade, da possibilidade de me desenvolver como um ser 
insubstituível. Qualquer serzinho humano é insubstituível, gente! É mesmo insubstituível. Essa é a coisa do Deleuze, do Foucalt, do Guattari, dessa turma aí. Você está sempre se criando, não pode se descuidar, porque você está criando a sua singularidade. Você não tem modelo. Você tem que ser um inimigo da modelização. Mas você já está vencido pela modelização... E você é jovem, tem que ser criativo, você tem que reagir. Eu espero assistir isso, porque o Rio Grande do Sul, politicamente, é o único estado do Brasil em que alguma coisa viva está sendo feita nesse sentido.

Eu gostaria que vocês compreendessem o que é pegar um governo. E esse governo ter esses muros modeladores, opostos a tudo o que você sente, deseja e sonha para a sua comunidade. É dentro desse Estado, desse tipo de Estado criado pelo liberalismo, estruturado pelo neoliberalismo, é dentro desse Estado que nós temos que emergir e apertar, abrir os braços contra as paredes. Isso é uma dureza, no diaa-dia é um sacrifício, um sofrimento, mas é também uma alegria: de ser possível uma vida nobre, criativa, humana..., também compensadora!

Eu quero que vocês resistam à modelização da universidade. Temos que resistir a tudo o que nos enclausura; seja religião, seja psicanálise, seja psicologia, seja cultura, seja o que for. Nós temos é que saber que nós, em cada instante, nos criamos e somos, ou não nos criamos e nos sujeitamos, aí não somos.

Não é uma anticultura, é uma anticultura mercadoria. Não é um antissaber, pelo contrário, é uma descoberta de que o único jeito de saber é saber junto. É uma coisa de Botsatwa, quer dizer, nós não vamos ao Nirvana se não formos juntos!

É isso que eu venho propor para vocês, ou todos juntos, ou ninguém, ficar nesse inferno aqui aguentando a mão.

Eu teria mais algumas coisas para dizer, mas eu acho que já passou o meu tempo. O que eu quero dizer mais para vocês, é que eu não gostaria de deixar uma impressão que eu sou desiludido da vida. Eu sou tarado pela vida! Com 72 anos eu gosto das coisas. Gosto mesmo! Acho que vale a pena e quero continuar aqui. Poesia, música, o saber, o poder conversar, dialogar, ser contestado... Só essa coisa de modelização, a produção de fora da subjetividade, isso não dá mais, não dá mais.
Então eu peço para vocês, humildemente, que acreditem que eu não vim aqui dizer "não vale a pena"; não, eu vim dizer que vale a pena! Vim dizer para vocês que nessa área (psicologia) - mas hoje não tem mais área, hoje tudo é multi, é pluri, pluri-institucional - nós temos que descobrir em última análise... deixa eu ver se eu consigo traduzir isso com simplicidade. Por exemplo, se vocês pensam num Estado, trabalhando no estado do Rio Grande do Sul, neste tipo de estrutura. O que eu quero dizer para vocês é que esta estrutura é uma estrutura institucional, vocês sabem. Agora, toda a institucionalidade contém em si mesma uma negação desta institucionalidade. Quer dizer, uma exigência de renovação, de recriação. Também ali não é só a minha pessoa que se recria em cada instância, que se redescobre. Eu tenho que reinventar tudo, inclusive o Estado, inclusive a institucionalidade. E para reinventar a mim mesmo, reinventar a institucionalidade, eu tenho que descobrir essa força, essa negação da institucionalidade existente. Essa negação da modelização que me faz ser este idiota que eu sou todos os dias. Tenho hora até para transar. Não pode ao meiodia, tem que ser de noite. Tenho vontade de dia e espero a noite para fazer.

Então, gente, com toda a simplicidade, eu preparo esta mensagem para vocês: resistam... inventem a vida, não deixem esse fluxo eletrônico, tecnológico da inteligência modelar tudo: o vestido, a cueca, a calça... ah não, gente! O vestir já é uma forma de propor algo. Não é uma coisa inerte, não é que o você veste para tapar o corpo. Não. Você propõe algo com o que você veste, ou com o que desveste. É impossível não propor algo, o outro esta aí para testemunhar. E se você quer se zerar, quer calar, quer não significar nada, não adianta. $\mathrm{O}$ outro lhe dá o sentido do sem-sentido. Então, a vida é uma coisa maravilhosa por isso mesmo. Se ela fosse fácil, aí a gente aconteceria quase que normalmente. É preciso fazer acontecer, inclusive a felicidade. Não como uma coisa definitiva e sólida, mas como um modo de autocriação, um modo constante de singularização, um modo constante de provar que somos realmente, cada um de nós, insubstituíveis, perante o outro. Pois, sem o outro, até substituíveis seríamos. Muito obrigado! 


\section{Intervencion e campo de intervencion}

Alejandro Raggio

Como apertura a la presente comunicación, quiero hacer referencia a la dificultad que implica salvar La paradoja del acto escritural. El texto parece, casi que inevitablemente, adquirir un esatuto definitivo: queda escrito y tiende a ser considerado fuera del proceso del que emerge. Por eso, quiero situar lo que sigue en un "diciendo"; de esta forma, el texto adquiere su justo estatuto: un momento reflexivo del proceso de investigación en que me encuentro. Algo así como un "informe de avance", en el cual la forma del gerundio es la que más parece corresponderle ..

Estas líneas constituyen basicamente, una versión corregida y ampliada de la intervención en la Mesa Redonda "Estratégias e intervençoes em comunidade". Si bien mantiene los ejes de análisis que en aquel momento la orientaron, se agregan algunos tópicos que profundizan dertas temáticas, o bien abren a problemáticas que adquirieron relevancia en el propio Encuentro y que no estaban previstas en la versión original.

Cuando acepté la invitación que cordialmente me hicieron los profesores N.Rivero y A.Henz de la ABRAPSO, lo hice sabiendo que para enunciar algo inteligente a propósito de la intervención en el campo comunitario y en un Encuentro de Psicología Social, iba a ser necesario darle una fuerte intensidad crítica a la colocación. Lo anterior se fundamenta en el hecho de la existencia de un conjunto importante de naturalizaciones, que entran en juego cuando se convoca una discusión acerca de estos tópicos y que además de ser un obstáculo, vuelven las reflexiones y discusiones poco interesantes.

\section{Algunas consideraciones iniciales}

Entre las naturalizaciones se destaca la insistente emergencia de una dicotomía - más o menos explícita - entre campo clínico y campo comunitario. Dicotomía ésta que, además, tiende adejar fuera del campo de conocimientos de la psicología social la problemática de la intervención clínica.

Si bien es cierto que lo anterior se puede explicar por una también "natural" identificación de la psicología social con los ámbitos grupales, institucionales y comunitarios, esta explicación no parece ser suficiente. De hecho, esta identificación, muchas veces funciona asociada a una cierta descalificación de la clínica, fundamentada, ya sea en una crítica de sus fuertes endurecimientos institucionales y corporativos, ya sea en los problemas que ubica su inocultable procedencia médica, o en su asociación li gera con el universo intimista y metafísico del sujeto individual.

Por otra parte, se sitúa otro problema, al que llamaría "la lógica de lo alternativo". La misma consiste en la ubicación de una propuesta en una lógica opositiva y en la paradojal repetición del modelo sustancialista que se le critica a las líneas de pensamiento ante las cuales es situada la propuesta "alternativa". En otros términos, desplazamos una Verdad, para inmediatamente situar otra en su lugar (esquizoanalítica, institucionalista) y que inevitablemente reproducirá la misma forma moral y moralizante.

Por eso, uno de los principales ejes que orienta esta comunicación es la pregunta del como pensar una modalidad de intervención que no funcione como un apriori prefigurativo del campo de intervención y del priopio campo de reflexión teórica? Este es, desde mi punto de vista, un interesante problema estratégico.

De esta manera, queda más o menos fundamentado, el requerimiento de reflexionar sobre estas cuestiones, desde una perspectiva que genere visibilidad sobre nuestros propios procesos de implicación con las lógicas de sentido dominantes.

El otro aspecto que sostiene esta reflexión es una puesta en entredicho de la separación radical entre campo de intervención y campo de análisis. En esta herencia institucionalista, está jugada, implicitamente, la cuestión del "artificio técnico", como implementación extrana al campo, ajena al proceso en el que se interviene. Es a partir de la crítica de esta separación, que situamos la reconsideración del campo de análisis como singularización inmanente al campo de intervención.

Desde la perspectiva aquí trabajada, la intervención no es un problema técnico y ni siquiera de estrategias pasibles de ser situadas a priori, es básicamente un problema ético.

Por eso, antes que introducimos en callejones sin salida de carácter técnico, preferimos interrogamos acerca de las condiciones mismas de la 
intervención psicológica: el campo de intervención (se trate de la entidad empírica que se trate), la formulación de los problemas y el diseno de estrategias, y la naturaleza del espacio analítico.

\section{De la naturaleza del campo de intervencion}

Nos resulta bastante habitual delimitar la especificidad de un campo de trabajo de acuerdo a una división en ámbitos de prácticas. Desde este punto de vistatendríamos, ámbitos educativos, institucionales, laborales, comunitarios, etc. Es decir, una taxonomzación que nos presenta la realidad en "ámbitos", establecidos en función de una evidencia empírica, más o menos sobrecodificada por diferentes lógicas de sentido.

Asimismo, parece muy evidente que, para cada ámbito existirían estrategias, metodologías y técnicas específicas, y aún más, hasta roles específicos. En primera instancia, parece bastante comprensible que el rol de un psicólogo en el ámbito clínico, no puede ser el mismoque tendría en un ámbito comunitario.

Pienso que, dada la consistencié!, del conjunto de creencias al que los ejemplos anteriores pertenecen, tenemos de antemano un problema en el que debemos detenernos. Si el asunto fuera tan sencillo, bastaría un buen adiestramiento técnico para operar en un determinado ámbito. Por otra parte, los encuentros académicos se verían reducidos a una suerte de actualización, presentación e intercambio de tecnologías más o menos eficaces.

Una primera deconstrucción del problema deja al descubierto, tres lineas de sentido predominantes: la evidencia empírica,las lógicas técnicas y los objetos disciplinarios. Estas trabajan comunmente juntas, yustaponiéndose y colaborartdo a generar aquello que acostumbramos a reconocer como objeto de nuestras acciones. De ahí que, esta discriminación tiene la finalidad de hacerlas visibles y no de describir las cosas como "realmente son".

Para ejemplificar lo planteado, tomaré aquello que desde el título de la Mesa nos convoca: la Comunidad. A principios de los anos 60, con la aparición de la estrategia de la APS, se empieza a privilegiar el campo comunitario como campo ,de prácticas para los profesionales de la salud. Sin embargo, esta jerarquización de lo comunitario, va asociada a la producción de una noción de comunidad, funcional a los requerimientos de la estrategia . Estrictamente, "la Comunidad" es una noción teórico-técnica, una particular codificación del campo social-comunitario, que busca hacer operativo este campo a los fines de la estrategia referida.

Si bien es derto que no existe un pensamiento metaempírico consistente que acompafie estos desarrollos, sí nos encontramos con la existencia, más o menos eficaz, de una objetivación del campo comunitario, que lo articula naturalmente como campo de intervenciones sanitarias.

El ejemplo es tan sólo eso, un ejemplo. Ocurre lo mismo con los procesos colectivos, frecuentemente capturados bajo una noción de grupo que los articula como objeto de intervenciones técnicas y desarrollos teóricos disciplinarios.

De esta forma, se anudan, las lógicas técnicas y los objetos, anticipando y encubriendo los procesos en los que se interviene. Se notará que, se trata también, de un complejo problema epistemológico y filosófico que, si bien es imposible profundizar en este espacio, debe ser necesariamente sefialado .

Ya sea considerándolos o no, siempre intervenimos en procesos subjetivos. Ya no hay, desde esta perspectiva, "individuos", "grupos", "organizaciones", "comunidades", ontologicamente establecidos, o se a, cuerpos naturalmente organizados. Y si parece haberlos, o bien serán alucinaciones técnico-disciplinarias de nuestra mirada, o bien cristalizaciones que no dejan de ocultar los complejos procesos subjetivos, sus agenciamientos colectivos y sus maquinaciones deseantes.

El campo de intervención ya no podrá ser definido por ninguna modelización teórico-técnica, ni evidencia empírica (ámbito) alguna. Sólo entonces, podrá ser pensado como red de composición: es decir, plano de inmanencia, entendido de acuerdo a las relaciones que lo constituyen, los segmentarizaciones que lo atraviesan, los actores que en el se articulan y las formas organizativas que, con mayor o menor rigidez, se ha podido dar a sí mismo.

\section{De la naturaleza del campo de analisis}

Para iniciar este apartado, quisiera convocar una perspectiva - nada "alternativa" - que, a pesar de ciertas posmodernas pretensiones de olvido, 
sigue interpelando la arrogancia técnica y promoviendo la reflexión ahí donde se la quiere evitar. Me refiero a la perspectiva abierta por Freud en el campo psicológico. La propuesta psicoanalítica, más allá de su particular hipertrofia institucional y corporativa, promovió una inflexión ética y metodológica cardinal: el lugar del médico, del experto, es desplazado y la producción de saber (sentido) se resitúa en una dialogía entre paciente y analista.

A modo aclaratorio, no interesa la procedencia del ejemplo (la clínica psicológica individual), ya que, lo que importa, una vez más, no viene dado por el dato de los sentidos. Poco importa si estamos trabajando con un sujeto, con una família o con una organización; lo que interesa - y para eso fue convocado Freud - es como estamos trabajando. Desde un punto de vista metapsicológico, que el psicoanálisis oficial haya encerrado en el universo intimista y burgués del individuo, toda la problemática de los procesos subjetivos, no debería ser para nosotros un problema. Por otra parte, la reducción de la práctica psicoanlítica a una sóla técnica, consagrada por las corporaciones oficiales, además de ser el correlato metodológico de lo anterior, es un efecto de fetichización mercantil que no puede tener mayor lugar en el campo académico.

La apertura de un espacio de análisis queda ubicada en esa dialogía, en la cual el sentido acerca de lo que se manifieste como padecimiento o conflicto, es inevitablemente un sentido a producir, no está dado a priori. La cuestión central, será entonces, abrir en el campo de intervención la perspectiva crítica del problema.

Coloco la idea de problema por varios motivos: por una parte ésta supone una ética que nos previene de la arrogancia profesional, la ética del investigador, quien a priori debe reconocer su ignorancia acerca de aquello que investiga. Por otra parte permite una articulación de análisis e investigación que facilita el rescate la labor analítica de sus endurecimientos profesionalistas.

En ella está jugada, además, otra cuestión ética cardinal: lquien formula los problemas? El problema no está dado, no es lo que empiricamente se percibe, lo que se enuncia como sufrimiento o conflicto, éste requiere necesariamente una formulación y el soporte de su formulación es precisamente la estructura dialógica.
Si resignificamos el aporte psicoanlítico y ubicamos el espacio de análisis en una dialogía inmanente al campo, fue fundamentalmente para resituar la reflexión acerca de la intervención y de la función analítica en una perspectiva ética.

Pierden importancia entonces, ciertas cuestiones en relación a la supuesta diferencia entre campo de intervención y campo de análisis. Si el campo de análisis no es inmanente al campo de intervención, no es campo de análisis, es otra cosa. El campo de análisis es un espacio diferencial en el campo, pero no diferente. Se trata de dejar de concebir la implementación de un dispositivo técnico como un "artificio" - por extensión "artificia1" - y de hacer bien visible la línea que separa intervención y manipulación técnica.

Por otra parte, desde una perspectiva filosófica, la separación entre campo de intervención y campo de análisis "cae en la vieja dualidad metafísica (...) entre empiria e idealidad conceptual, operatoria y esquema nocional, o concretamente entre campo de intervención y campo crítico o de análisis".

El campo de análisis o espacio analítico es un espacio diferencial que se forma pm singularización a partir del propio campo de intervención, un pliegue de ese mismo campo que reflexiona sobre sí mismo y sus sentidos posibles. Desde aquí, la dimensión técnica, no es otra cosa que una implementación instrumental específica destinada a la apertura y sostén del espacio de análisis.

Si seguimos desplegando la metáfora espacial, nos vemos requeridos de continuar la reflexión ética. Detenerla en la naturaleza dialógica del campo de análisis, implicaría perder de vista la dimensión social del acontecimiento analítico, es decir la práctica analítica en tanto práctica social. Por eso, no se trata solamente de reestablecer procedencias familiares y regenerar conexiones, sino también de producir las condiciones a través de las cuales el otro se reconozca formando parte activamente de la realidad social.

La metáfora espacial (pliegue), además de permitirnos una reconsideración crítica del dualismo campo de intervención-campo de análisis, posibilita pensar al espacio de análisis como una lógica de subjetivación, reflexivamente establecida y articulada en una continuidad topológica con el espacio social. 
La práctica psicológica y su dimensión analítica, en forma genérica, se articulan dentro de lo que A.Giddens denomina reflexividad de las formaciones sociales. Es decir, son prácticas, más o menos institucionalizadas, en las cuales, con el uso regularizado del conocimiento teórico y técnico, se configuran regímenes en los cuales los sujetos se reconocen y se significan .

Esta ubicación social de las prácticas psicológicas, es la que permite el despliegue de la reflexión ética en toda su amplitud. Desde ella, ya no será posible desconocer los sentidos sociales de la intervención psicológica, se cual fuere el campo en el que se interviene, así como, tampoco será posible desconocer el requerimiento de analizar la implicación con las lógicas de sentido en las que se articulan los actores de una intervención concreta.

Si bien muchas de las hipótesis y afirmaciones que he dejado plasmadas en esta breve comunicación requieren un desarrollo más extenso, entiendo que, desde estos parámetros, podríamos resituar el problema de las estrategias de intervención. Ubicando una perspectiva en la cual, éstas (Ias estrategias) no queden capturadas en ninguna lógica trascendente, sino que operen de forma de potenciar una práctica psicológica dirigida al sostén inmanente de la producción deseante y de la interrogación acerca de sus modos de existencia. $\mathrm{O}$ se a, el sostén de la vida misma y de una interrogación de sus modos de producirse, sus bloqueos, sus frenos, sus sentidos actuales y posibles.

\section{Elogio de la herejía}

Gabriel Eira

\section{I - Los prodigios de la doctora Micka}

Cuando Colorado Spring (Colorado, USA) no era más que una pequena aldea habitada por unas decenas de colonos, en algún ignoto lapso de la segunda mitad del siglo XIX, la doctora Michaela Queen ejercía su profesión al tiempo que conjugaba una suerte de doble actividad pionera: la inherente a su condición de colona, y la de adelantada en la lucha por los derechos de la mujer. Debo reconocer que me fascinaba aquella serie televisiva de los domingos; por su militante anacronismo, por la cuidadosa cursilería de su moralina ingenua (al mejor estilo de series de mi infancia, tipo "Una casa en la pradera" conocida en estos lares como "La familia Ingalls" ), pero fundamentalmente por su disparatada capacidad para producir - capítulo a capítulo - un homenaje a lo inverosímil.

Así como ellegendario Peko's Bill - paradigma de la hiperbólica imaginería popular norte americana - fue responsable de la existencia del Río Bravo gracias al filo de su navaja, la doctora Micka era protagonista de hazafias no menos meritorias. Fue capaz de extirpar exitosamente un cáncer de mama, de realizar cesáreas y de reparar quirúrgicamente el rostro de un paciente deformado por el fuego, eludiendo la necesidad de los anestésicos y de los aún desconocidos antibióticos. Y todo ello en una casilla de madera decorada con el polvo de los caminos de tierra. Pero, además, era pionera en el alpinismo femenino, abanderada de los derechos de las minorías, ferviente ecologista, y una suerte de Forrest Gump decimonónico con faldas que coincidía con cada acontecimiento fundacional en la historia de los Estados Unidos. Hasta consiguió ir a festejar el día de Acción de Gracias en una reservación indígena, convenciendo a los Pieles Rojas brindar alegremente por la llegada del Mayflower y el inicio de su propio genocidio. Y la cereza de la torta; uno de sus hijos adoptivos, el menor, fue el responsable del diseno de curiosos ingenios aéreos asombrosamente parecidos al que muchas décadas después los hermanos Wright lograran hacer volar para pasar a la Historia.

Pero todo indica que lo inverosímil no nace de una deliberada opción estética sino de la cuidadosa capacidad analfabestia, o al menos el descuido, 
de los libretistas. Esto no es nuevo en el show bussines norteamericano, nos hemos cansado de ver osos polares dialogando con pinguinos, a animales de sabana deambular por la jungla, y a mariachis durmiendo la siesta en las calles de Rio de Janeiro. Tan acostumbrados estamos a ello que sólo lo percibimos cuando nuestra pequena república aparece marginalmente en la pantalla; en Maratón de la muerte se inicia una cacería de nazis en el interior de la jungla uruguaya (!), en Viven el mate se prepara sacudiendo la bombilla como si de café instantáneo se tratara (!!), la maestra del cartoon de la família muerta explica a sus ninos que en el país de la penillanura se producen - exclusivamente - bananas (!!!), en La batalla del Río de la Plata circulan góndolas sobre la bahía de Montevideo (!!!!). El genio publicista de Gõebbels postuló que una mentira repetida míl veces se transforma en verdad. Tal vez por ello no consigo convencer a mi hijo de que los osos polares habitan en el Ártico mientras que los pinguinos lo hacen en la Antártida, no puedu competir con la industria del Cartoon. Pero el carozo del asunto no radica en la verdad o falsedad del enunciado sino en su verosimilitud, en la ingeniería de sentido con la que éste se construye.

\section{II - La epifanía del disparate}

Es necesario reconocer que resulta útil recurrir a la epifanía del disparate para abrir alguna visibilidad sobre este asunto de la construcción (y, de allí, la imposición) de la verdad o, lo que sería más correcto, los efectos de verdad. La distancia entre lo dicho y aquello sobre lo que se dice se toma más clara cuando el absurdo lo denuncia (aunque, vale sefialarlo, la propia cualidad del absurdo es también un constructo). No pretendo extenderme sobre el asunto, solicito sí que se me conceda una hipótesis instrumental; la verdad, lejos de ser una cualidad ontológica (es decir, una propiedad del ser, autónoma de la inteligencia que lo describe), es el producto de un proceso constitutivo, sociohistóricamente diagramado. La verdad, entonces, no sería una propiedad de las cosas que ellenguaje designa, sino el efecto de las formaciones discursivas que le otorgan sentido. Desde esta perspectiva, el carozo del asunto no reside tanto en si lo que se dice es falso o verdadero, sino en los procedimientos por los cuales tales cosas pasan a ser consideradas de una otra manera. Dicho de otro modo, la verdad no radica en el acierto con el que un ejercicio enunciativo describe al universo sino el coeficiente de verosimilitud (la capacidad para ser considerado verdadero) del mismo.
En estos procedimientos, el absurdo (insisto, él mismo un constructo) posibilita el acceso a un analizador privilegiado, pues permite -al quedar descalificado por la incongruencia-atender a cómo éste se instituye como verdad. De este modo, puede ser visible el conjunto de procedimientos desde los cuales la verdad se erige como axioma (es decir, una verdad que no necesita ser demostrada). Y es que el axioma - por tal - constituye certezas, éstas convocan adhesiones, y desde ellas se conforman los consensos que la legitiman. Es a esto último que llamo efecto de verdad.

\section{III - El recurso Tinelli}

En los últimos afios, el Río de la Plata ha asistido al ascenso al estrellato de una técnica mediática con características particulares. Tal vez el antecedente más célebre sea el del pierrot argentino Marcelo Tinelli. Si bien Videomatch no inaugura el humor chabacano sí instituye una fórmula extremadamente exitosa; hacer de la burla, la descalificación chauvinista, y la imprecisión (por no decir el error alevoso) una forma legítima de ilustrar la noticia. Este procedimiento ha hecho escuela, no sólo en la capital portefia sino también en nuestras producciones vernáculas. Incluso en esferas oficiales, como cuando el expresidente Menem cita a Sócrates como autor de cabecera (!) y condecora a Fujimori por haber terminado con los Tupamaros, con total impunidad, sinque al establishment se le mueva un pelo. El brillo del espectáculo cobra tal magnitud que el disparate se desdibuja y,lo que es peor, se torna verosímil. Por esas mismas fechas, y en nuestro país, quienes antes justificaron la sangrienta represión policial en el asunto del Hospital Filtro (en función de respeto doctrinario que se debe tener a los Fallos del Poder Judicial) eran los mismos que se rasgaban los trajes a medida por el asunto de Braga y Cambón y pretendían sancionar al fiscal actuante, del mismo modo que intentaron entorpecer la acción judicial en el tema de los desaparecidos. Desde el Círculo Militar se invitaba a la conciliación nacional y al olvido de los "hechos acaecidos hace 25 anos" mientras conmemoraban a los "caídos en la lucha contra la sedición" y se oponían a un tratamiento similar a las víctimas de su propia actuación. Cuando emergieron números truchos en la economía del Ministerio del Interior las auditor as responsables del diagnóstico fueron suspendidas en nombre de una "investigación administrativa". 
La epifanía del disparate se impone también como tecnología política. La tecnocracia de nuestros modelos económicos se congratula (y cuando no puede hacerlo recurre a los factores externos y afirma que si tales modelos no se hubieran aplicado la cosa hubiera sido aún peor) por el supuesto éxito de sus estrategias en función del crecimiento de la econornía, entendiendo por tal a los guarismos macroeconómicos ignorando la emergencia de la desocupación y el subempleo. Se fundamenta el mejoramiento del nivel de vida en función del mercado automotor y los televisores del Géant, al mejor estilo de María Antonieta y su senalamiento sobre las tortas. Se apuesta a un país de Servicios a partir de la habilitación de institutos terciarios (algunos dignos de república bananera) sin fundamento académico, al tiempo que se pauperiza la UdelaR intentando transformarla en una fábrica de diplomas virtuales y en una máquina de captura para la clase-media desempleada.

Pero, insisto, no importan tanto las incongruencias como sus efectos de verdad.

En nuestra propia programación televisiva (y radial) es posible encontrar vestigios de la metodología Tinelli. Y no sólo en aquella mala copia que emitía, hace algunos anos, el canal oficial. No sólo en el formato de producciones posteriores como Noche de Miércoles por el canal 12. E1 4 de abril, en el nuevo formato (cada vez más Tinelli) de Rompecabezas (CX 14, El Espectador) se le atribuye a Sadamm Husselm la presidencia de Irán (!!), y se bromea sobre el velo de las camboyanas. En el circo de Debate Abierto (canal 10) se llega a discutir durante todo un programa sobre la legalización del consumo de drogas sin que a la producción del programa se le halla ocurrido averiguar si en el Uruguay el consumo era, efectivamente, ilegal. Esto último me resulta particularmente significativo. La legislación vigente no prohibe el consumo de nada, sólo el suministro y la comercialización (y sólo en ciertas condiciones) de algunas sustancias mallamadas estupefacientes. Sin embargo, como demuestran los interminables debates sobre la legalización del consumo, se instituye la prohibición como orden natural (se naturaliza) cuando no es tal, con los consecuentes efectos sobre el consumidor (adicto o no), desde la tipificación colectiva a los haceres del aparato policial. Un ejemplo de efecto de verdad; el consumidor (sólo por el hecho de serlo) es un delincuente, aunque la ley no lo prescribe de tal manera (es más, lo ampara).

\section{IV - American Pie}

El caso de los EEUU merece un tratamiento específico que excede las posibilidades de estas carillas. Pero bien vale una vmeta. Esa encantadora tendencia a mirar (y juzgar) al mundo (y la historia) desde los pliegues de su ombligo, hace que el American Way of Life (y lo que ello pueda significar) no sólo se instituya a sí mismo como el mejor sino como el único moralmente posible. El modo de ser norteamericano se pretende el mejol; precisamente porque está convencido de ser el modo natural del animal humano. Por ello el Destino Manifiesto; el Vigía de Occidente, no puede evadir la responsabilidad de tutorear a sus hermanos menores (esto se ha vuelto inevitable desde la instauración del New Order Mundial), está moralmente obligado a ello, en tanto se considera el custodio de los valores elementales de la naturaleza humana.

No deja de maravillarme, pese a todo, los anacronismos de la narrativa hollywoodense, sobre todo porque no parece ser un recurso estético sino pura y exclusivamente cronocentrismo estadounidense. Salvo muy honrosas excepciones, la psicología de los personajes suele ser planteada como la misma, en un hombre del Renacimiento, en un celta de los Highlands, o en un cortesano del "Imperio Galáctico"; asombrosamente parecida a una suerte de caricatura del norteamericano medio (o lo que se pretende creer sobre él). Así, en "Corazón Valiente" las masas escocesas van a morir tras un paladín que defiende un paradigma inexistente hasta el siglo XIX; el nacionalismo y el mito de estado-nación. En "Cristobal Colón" Gerard Depardieu sostiene una discusión con su "esposa" extraordinariamente similar a la de una pareja pequeno-burguesa de Seattle. Las lógicas de sentido del American Way of life se pretenden universales y a-históricas, legitimación inapelable del Destino Manifiesto.

En función de la ideología de frontera, y el culto a los pioneros, los WASP han impuesto el modelo del hombre hecho a sí mismo y el sobredimensionamiento del voluntarismo; "si lo deseas con la suficiente fuerza lo lograrás". En contra partida, se erige como paradigma de lo denigrante al vocablo "luser" (perdedor), tal vez el peor insulto que pueda sufrir el norteamericano medio (si es que éste puede ser definido de alguna manera). En la lucha por la supervivencia - y para esta forma de ver las cosas -, la condición del sujeto (conceptualizado como individuo) sólo puede ser produeto de su propio esfuerzo y quienes no logren triunfar en la 
vida no pueden ser más que culpables de su propia haraganería; perdedores. El individuo está sólo frente al mundo, y será adorado (aplaudido al final de la película) si logra imponer los designios de su voluritad, de lo contrario está condenado a la humillación del fracaso. La competencia se impone así como la condición natural del hombre, única fórmula legítima de regulación social, único motor del progreso. No en vano el béisbol se impone como deporte nacional; un jugador (el bateador) se enfrenta sólo a todo el equipo contrario; Johnny Self contra el mundo.

Estos procedimientos imponen estos efectos de verdad; la condición natural del hombre es la competencia, el hombre es un individuo en confrontación permanente con el mundo (y con los demás),la única forma legítima de evitar que esta lucha se convierta en una carnicería es a partir de la seducción de los incentivos (económicos) regulados de tal modo que redunden en beneficio de la realización personal. Corolario; el único paraíso posible se constituye a partir de la consolidación de la Ley de Mercado regulada por los acuerdos contractuales. Esta Verdad se impone, como resulta lógico, no solo hacia el interior de los EEUU. El Destino Manifiesto obliga a transformar-la en Verdad Militante, los misioneros del Mercado la expanden (si es necesario, a la fuerza) más allá de las fronteras. La libertad, en esta suerte de monoteísmo mercantil, no puede ser más que libre circulación de capitales y libre contratación. La propia condición los países del llamado Tercer Mundo corrobora esta hipótesis; son lusers, víctimas de su propia incompetencia.

Este orden de cosas se instituye como correla to subjetivo del New Order Mundial. Así, y paradójicamente,la que tal vez sea la más ideológica de las disciplinas (la Economía) establece a la lógica del capital como La certeza cientificamente inapelable, en el preciso instante en el que el absolutismo científico de la Modernidad comienza a desintegrarse y se pregona la muerte de las ideologías. De este modo, la discusión política queda reducida a la batalla entre keynesianos y neoliberales, descalificando toda opción asistémica tras el adjetivo de la utopía política (tan carente de verosimilitud como de pragmatismo). No es casual que el nipo-americano Fukuyama (quien insiste en definirse como "neohegeliano") se atreve a profetizar el Fin de la Historia, sepultada tras la emergencia definitiva del homo natura de las nuevas sociedades democráticas que tanto admira Lipovetsky. Es que el corolario resulta ineludible; en la medida en que el
Hombre alcanza, por fin, el libre ejercicio de su naturaleza última, la flecha del tiempo que parte desde las ravernas consigue llegar al objetivo de la emancipación. La Historia muere, para dar paso a la suprema manifestación de la naturaleza humana. El animal humano es (siempre ha sido) lo que recién hoy habríamos llegado a comprender; una individualidad en perpetua competencia con las demás. El Contrato Social de Rosseau adquiere así legitimidad científica gracias a la esforzada labor de los tecnócratas de la Economía Política. La Verdad queda revelada; no se opina sobre ella, se la acata. Negar la Verdad no sería (no podría ser) - entonces - el efecto de una analítica, sino una suerte de patología del pensamiento, la resultante ideológica de un delírio o - en el mejor de los casos - un grave erro $r$ producto de la ignorancia.

En el breve lapso de la Postmodernidad, en el cual se pretendió erradicar la certeza, se instituyó - sin embargo - la impostura de una nueva axiomática que identifica la naturaleza humana con los anaqueles del supermercado. De este modo, emerge el diagrama de una nueva doctrina que, al hacerlo, posibilita la tipificación de la disidencia como pensamiento herético. Los nuevos herejes serán quemados en la hoguera de las descalificación académica y la burla política, tan efectiva como aquella en la que ardían las víctimas de la Inquisición.

\section{V - La hoguera de las vanidades}

El nombre del Papa era Inocencio III. En el segundo ano de su pontificado, 1209, Su Santidad llama a una nueva cruzada. Esa vez no se trataba del Santo Sepulcro, nada tenía que ver el Islam con esta nueva convocatoria al asesinato. Satán, el gran adversario, ya no localizaba sus huestes en la Palestina bíblica sino en las cristianisimas tierras de Felipe, rey de Francia.

Era la Quinta Cruzada (hay quien así no la cuenta precisamente por haberse ubicado el teatro de operaciones en la Europa Occidental),la Cruzada contra los albigenses.

Se trataba de eliminar la herejía cátara, objetivo cumplido con extraordinario éxito. Tan es así se ha borrado la memoria histórica sobre ella, haciendo de su doctrina concreta un misterio habilitador de las más fantásticas especulaciones. En el sur de Francia (Provenza, en la legendaria 
Langue d'Oc) se había consolidado este desvío del dogma, bajo la protección del conde de Tolosa (hoy Tolouse).

Inocencio ordenó la colaboración de los arzobispos, los caballeros y el propio Felipe. Nombró un nuevo legado (su propio secretario, Milton) y, como adjunto, a maese Teodosio. al frente de veinte mil caballeros y una tropa de infantería constituida por más de doscientos mil aventureros, designó a Arnaud-Amalric como generalísimo del ejército. Es en Letrán donde se lanza la llamada, el 6 de marzo:

A los que sean virilmente cefiidos y armados contra estos pestíferos, se les promete la remisión de sus pecados, acordada por Dios y su Vicario.

La barca de la Iglesia está expuesta a un naufragio total si ante esa inaudita tempestad no se le presta un poderoso socorro.

Adelante soldados de Cristo.

Adelante, intrépidos novicios de la milicia cristiana.

Esforzaos por pacificar estas poblaciones en el nombre de Dios, de la paz y del amor. Aplicaos a destruir la herejía por todos los medios que Dios os inspire.

Primero cae Puylaroque, luego Gontand, Tonneins, Casseneuil y finalmente Montpelier (el 20 de julio). Los herejes alimentan la hoguera. La escena siguiente se desarrolla en Béziers. Ante la ciudad citiada el obispo de Citeaux, Reginaldo de Monpeiroux, propone a los católicos que entreguen a los herejes o - en su defecto - que abandonen la villa. El mensaje es acompafiado de amenazas de excomunión y asesinato. Sin embargo,los ciudadanos de Béziers responden que "se dejarán ahogar en el mar salado antes de consentir", se estrechan los lazos entre herejes y católicos para resistir a las fuerzas papales que se proponen asesinarlos "en el nombre de Dios, de la paz y del amor". "Juran que no darán nada a los cruzados (...) que podrían cambiar las leyes de su ciudad".

Cuando finalmente cayó Béziers, los cruzados interrogaron al generalísimo Arnaud-Amalric acerca de cómo proceder durante la matanza para discriminar entre herejes y católicos. Ante ello, el enviado del Papa respondió: "Matadlos a todos, Dios reconocerá a los suyos". Finalmente, en el informe que el comandante envió a Inocencio III, se destaca (sic): "Los nuestros no respetan ni el rango, ni el sexo, ni la edad; han hecho perecer bajo la espada alrededor de veinte mil personas, y después de una enorme matanza de enemigos, la ciudad ha sido saqueada y quemada. La venganza divina ha sido maravillosa".

La Verdad había sido reconstituida. Todo desvío implica un peligro para la doctrina, la barca de la Iglesia está(ba) expuesta a un naufragio total. La no-creencia de la herejía pone en duda la creencia del dogma, motivo por el cual merece ser exterminada. El procedimiento por el cual la Verdad se instituye como tal reside en la verosimilitud que la impone como axioma (premisa que no precisa ser demostrada), esta verosimilitud se sostiene en el consenso, por lo cual todo desvío que atente contra el acuerdo colectivo pone en cuestión al propio axioma (lo que no hace más que desdibujarlo). No se trata, entonces, tanto del contenido de la herejía como del procedimiento (el disenso) que la constituye como desvío de la doctrina. Antes de lo qué se cree,lo que importa es qué no se cree, y cómo no se procede. Lo que está en cuestión es el principio de autoridad que estatuye cuál es la Verdad y la existencia de la propia Verdad como ontología. En la anécdota, el poder constitutivo de la Verdad, la convicción, es tal que -ante la duda- ella misma se encargará de discriminar la pureza de la impureza: "Matadlos a todos, Dios reconocerá a los suyos".

En los últimos afios, y salvando las distancias, hemos asistido al despliegue de ciertos procedimientos similares que lograron ocupar un papel protagónico en nuestros vernáculos medios masivos de comunicación. El caso es el de una familia naturista de Tarariras que se negaba a vacunar a sus hijos, incluso exhibiendo certificados médicos que testimoniaban -en razón de su particular (por minoritario) estilo de vida- el peligro que la vacunación podría significar para los nifios. El axioma de la necesidad del plan de vacunas obligaba a impedir, por el bien de ellos ("en el nombre de Dios, de la paz y del amor"), que los infantes accedieran a la educación formal si no se vacunaban. La abstinencia de esta actividad axiomática hacía de estos chicos un peligro para sí mismos y para la comunidad, un posible foco infeccioso que amenazaría a los demás nifios; "Ia barca de la Iglesia está(ba) expuesta a un naufragio total". Más allá de los aspectos epidemiológicos, lcuál era el foco infeccioso?, Lqué Verdad estaba en cuestión? Todo parece indicar que el mayor peligro se relaciona no con una verdad en particular sino en el procedimiento que configura a la Verdad 
misma como categoría. Y, en este caso en particular, con el principio de autoridad médica. Autoridad Médica, no autoridad del médico, el cual es trascendido por la disciplina que lo contiene.

Recuerdo un programa de televisión abierta en el cual el padre de dicha familia polemizaba con una representante del Ministerio de Salud Pública (médica ella). Mientras el hombre intentaba exponer sus razones, y legitimarlas desde una multitud de informes médicos, la doctora insistia en no conceder excepciones al programa de vacunación (axiomá tico), se negaba a discutir las particularidades del caso. El padre no negaba la utilidad de las vacunas, pero reivindicaba su situación particular, la cual no terminó de exponer ante la negativa de la médica y la complacencia del periodista coordinador. Solicito que se me conceda atención a este punto. Más aliá de la efectividad (o no) de la imunización lo que estaba en juego aquí era el principio de autoridad. No importaba tanto si en esta singularidad tal procedimiento podría ser beneficioso o peligroso (no se dio lugar al asunto), sino el precedente que la misma pudiera sentar sobre el axioma mismo (el programa de vacunación). Ante el posible desvío se hizo necesario reconstituir la Verdad, la posición de esta familia fue tipificada como ejercicio herético, y como tal debía ser excomulgado del seno de la Medicina y la Salud Pública. La excepción confirma la regIa configurando una perversión de la misma. No se debe dar lugar al espacio que habilite un paréntesis en el consenso. No hay consenso sin unanimidad, sin consenso el axioma pierde sus cualidades, y sin axioma el principio de autoridad se debilita. El desvío debe ser aceptado como perversión, y como tal debe ser tratado, habilitando anticuerpos que lo descalifiquen. En la hoguera se queman las vanidades del hybris, ésta vez alimentada por el prestigio de la corporación médica, el interés nacional y el sentido común, articuladas en una suerte de dictadura inapelable del consenso. La Verdad ha sido reconstituida,la excepción no es verosímil.

\section{VI - Hairesis}

La etimología relaciona la palabra herejía con el término griego hairesis, el cual-literalmente- no refiere a otra cosa que a la acción de escoger y - por extensión - a la escuela de pensamiento escogida por tal acción. Ahora, más allá de tal procedencia, el uso adjetivo que solemos hacer del término resulta extremadamente significativo: f. Doctrina contraria a los dogmas de la Iglesia, sostenida con pertinacia por un hombre bautizado.

2. fig. Sentencia errónea contra los principios de una

ciencia o arte.

fig. Palabra gravemente injuriosa.

fig. fam. Disparate, error.

5. fig. Daño o tormento grande, infligido injustamente a una persona o animal.

¿Cómo fue que un sustantivo referido a la acción de elegir devino en adjetivo descalificativo, al punto tal de adquirir sinonimia con los términos error, disparate, dano o tormento? La Encidopedia Británica, citada por Thomas Szasz, proporciona algunas pistas:

“(...)Utilizado así,” (acción de elegir y conjunto de opiniones) “el término era neutral, pero en cuanto la cristiandad se lo apropió, comenzó a sugerir una nota de desaprobación. Esto fue porque la Iglesia, desde el comienzo, se consideró a sí misma como custodia de la divina revelación, la que sólo ella estaba autorizada para interpretar (...) de esta manera, cualquier interpretación que difería de la oficial, era necesariamente 'herética' en un sentido nuevo y peyorativo."

De esto se trata. Es posible encontrar el término en los Hechos de los Apóstoles y las Epístolas de San Pablo utilizado, entonces, para indicar sectarismo (en su significación más literal; celo doctrinario de un sistema que se independiza de otro). Una de las preocupaciones fundamentales del cristianismo primitivo era la progresiva fragmentación a la que tal sistema de creencias se hallaba sometido. En dicho contexto, se optá por una estrategia política de uso extendido: promover una doctrina (o un aspecto de la misma) al estatuto de Verdad (premisa axiomática) y descalificar a los sistemas competidores tipificándolos como especulativos, simples conjuntos de opiniones; hairesis. Por definición, un axioma no puede ser objeto de opinión, no puede ser interpretado; es. En función de ello, un desvío de lo que es, una interpretación que se aparte de lo que se considera correcto (la Verdad) configura, necesariamente, un error. La Verdad no puede ser opinada, sólo puede ser. La acción de escoger no es válida para la Verdad, al menos no si se quiere escoger certeramente. En tal sentido, toda 
escuela de pensamiento que profese una opinión sobre la Verdad no puede ser más que disparatada y necia. En la literatura cristiana posterior, el término va adquiriendo un valor cada vez más negativo. Esta progresiva degradacióndel término alcanza su climax con la institucionalización política del cristianismo en el Imperio Romano; los delitos de opinión religiosa (las herejías) pasaron a ser considerados crímenes contra el Estado, y como tales punibles por la legislación civil. La herejía adquiere su carácter peyorativo en el momento en el cual un sistema de creencias niega su carácter de tal y se promueve al estatuto de Verdad, más aún cuando dicho estatuto logra ser materializado por la norma jurídica. La resultante de esta promoción es la descalificación inmediata de quienes opinan sobre ella, y la consecuente asociación con términos tales como error, disparate, dano o tormento

Ahora bien, estos procedimientos trascendieron la materia religiosa para localizarse en cada lugar en el cual hubiera un status quo que proteger. Porque la duda, la incredulidad, el escepticismo y la excepción son elementos peligrosos para lo instituido. Hay una certeza a la cual el status no puede renunciar; la legitimidad del mismo. El propio Estado es un ejemplo de ello, y el fascismo su extremo más terrible. Mucho antes de que el término herejía fuera apropiado por la cristiandad, Sócrates fue condenado a muerte por introducir la duda en la juventud ateniense. Hete aquí aquello que seflalábamos antes; no importa tanto lo qué se cree como aquello en lo que no se cree. El Estado ateniense, en el lapso de su supremacía político-militar, no podía permitirse ellujo de la duda. No se debe, dudar sino acatar la legitimidad del orden establecido. La hairesis socrática costó la vida a su creador.

Solicito un paréntesis para unas vifletas fascistas: "La duda es la jactancia de los intelectuales" (Aldo Rico) y "Cuando escucho hablar de cultura hecho mano a mi pistola" (Göebbels). El pensamiento implica acto de elección. No hay pensamiento sin herejía, sólo reproducción. No hay pensamiento sin duda, sólo doctrina yacatamiento. No hay autoritarismo que no apele a la Verdad, así como no hay herejía que no interpele a la certeza. Cerremos paréntesis.

El propio Estado liberal (el cual se sostiene la presunción de la tolerancia) se desdibuja como tal a la hora de defender sus mitos fundacionales. Un analizador privilegiado de este fenómeno es la adoración 75 fetichista a los símbolos patrios (bandera, escudo, himno nacional), traducida en una legislación extremadamente restrictiva frente la herejía antipatriótica. El trámite que obliga a "jurar la bandera" no es más que un ejemplo de ello, por más burocrático que se halla tornado. Vale, también, recordar el horror que despertó - a medidos de los '90 - "El día que Artigas se emborrachó", en nuestra jerarquía política y la propuesta de legislar sobre la figura de Artigas en tanto símbolo patrio (es decir, no objeto de cuestionamiento), borrando toda posibilidad de investigación histórica seria.

Es Szasz quien lo subraya con claridad, la herejía trasciende lo errôneo o lo certero, su cualidad de tal radica antes en el procedimiento que en el contenido:

Una herejía lo es cuando lo correcto es hacer algo que está mal. Es insistir que dos más dos son cuatro cuando lo apropiado, lo patriótico, lo profesional, es decir que son cinco. Es creer que la tierra se mueve alrededor del sol cuando Lutero, Calvino, y el cardenal Bellarmine nos dicen que el sol se mueve alrrededor de la tierra.

Desde luego que sería un error pensar que lo herético es siempre correcto. No es así. Además, la herejía a menudo no tiene nada que ver con el bien o el mal, en el sentido literal -matemático o científicode estos términos. Sin embargo, sí tiene que ver con no creer en la que los demás creen o en lo que uno mismo debería creer, o en proclamar que no se cree cuando lo correcto sería profesar esa creencia o, al menos, permanecer callado.

Uno sabe que alguien es un hereje cuando los amigos y colegas lo confrontan con un incrédulo e indignado: ¿Quieres decir que no crees que...? Lo que uno no cree pudiera ser, por ejemplo, que los judíos constituyen un pueblo elegido; o que !esús es el hijo de Dios; o que Freud era un científico. Cada una de estas incredulidades es una herejía para aquellos que sí creen en ellas, pero no para aquellos que no las creen. Cuando un amigo psicoanalista me dice, sincera pero despreciativamente: ¿Significa que no crees en el inconsciente?' como si no creer en el inconsciente fuera algo así como no creer en el hígado -, es porque mi incredulidad ofende su credulidad. A un hematólogo o a un hebraísta le tiene sin cuidado si creo o no en el inconsciente, pero probablemente estará muy interesado en saber si creo o no en la causa genética de la leucemia o en la divinidad de !esús. Así es la cosa. La cuestión reside en que lo que es herético 
para una persona puede ser heroico para otra e irrelevante para una tercera.

La incredulidad, vale agregar, no sólo ofende a quien profesa la creencia en cuestión, sino también - y fundamentalmente - al status quo que tal credulidad sostiene.

\section{VII - Todos somos carlitos}

Un enorme galo llamado Karl, y apodado "EL Martillo" por la implacable efectividad de sus campafias, adquirió su pasaje a la fama consolidando, allá por el siglo VIII, la dinastía carolingia y deteniendo la expansión del Islam en la batalla de Poitiers (732). Pero el hijo más célebre de Pepino de Heristal (conocido por los hispanoparlantes como Carlos Martel), posee también el poco reconocido mérito de haber reivindicado el patronímico Carlos. Es que el nombre Karl proviene de una antigua palabra teutónica que designaba a la clase inferior de los hombres libres, la cual se degradó hasta adquirir la sinonimia de siervo. La palabra inglesa "churl" (patán) deriva de este vocablo, pero los éxitos castrenses de quien llegó a ser senor de Austrasia y Neustria impusieron su nombre como favorito en la aristocracia de Europa Occidental, haciendo olvidar su poco nobiliaria etimología.

Ahora bien, esta suerte de renacimiento de la medievalidad a la que nos ha tocado asistir, y del que ya se ha hablado, caracterizado también por la emergencia del pesimismo y la falta de credibilidad en todo proyecto de cambio, parece habernos transformado en "carlitos", en el sentido más teutónico del término.

Todos somos carlitos, patanes, fascinados por la seducción fácil del espectáculo, sin preocuparnos en lo más mínimo por la verosimilitud de los productos que consumimos (y confundiendo tal cualidad con una suerte de ontología de la Verdad). Carlitos de fonda suburbana, habitantes de un mundo neofeudal, cantamos a coro cantigas de cantina cuya única virtud consiste en la predecibilidad kitch de sus armonías. En el contexto de la neo-medievalidad se hace ineludible el elogio de la herejía, como herramienta imprescindible que nos permita exorcizar el olvido del pensamiento tras las pegadizas baladas de moda.

\section{Pensando em armas para a desinstitucionalização da psicologia social}

Tania Mara Galli Fonseca

Em primeiro lugar, gostaria de agradecer a oportunidade - que me oferecem os organizadores desse VIII Encontro da Abrapso-Sul - de juntarme ao conjunto de vozes que se dispôs a contribuir com a discussão da temática Psicologia Social: estratégias, políticas e implicações. Acolho esse importante momento com o mais caloroso desejo de que, nessa mesaredonda, a última de nosso Encontro, já possamos visualizar que a tarefa que nos une, desafia e vitaliza não se refere a nos certificarmos se ainda resta algo de vida na Psicologia, como interrogávamos há alguns anos atrás. Lá, e então, mirávamos a Psicologia como corpo inerte, engessado e mumificado por amarras emudecedoras e enrijecedoras. Um corpo governado pelas leis da tradição e do passado, corpo dos mortos, cuja configuração se mostrava ao mesmo tempo excessiva e insuficiente.

Hoje, o chamado corpo-Psi, em seu duplo formato de ciência e profissão, oferece-se ao exame como corpo ferido ao mesmo tempo que revigorado pela potência da crítica fecundadora e flexibilizado pelo acolhimento de novas demandas... corpo aberto, em vívida mutação e que, desmanchado e descontruído, busca reterritorializar-se, enquanto se torna campo de passagens e disputas discursivas. Nele coexistem características de aparelho de reprodução e captura e as de máquina de guerra, podendo-se vislumbrá-lo também como locus maquínico e de produção, como tecnologia da inteligência que pode estar colocada a serviço da emancipação do pensamento e do desejo e, portanto, inventora de novos sentidos para os sujeitos e seus mundos.

Falar aqui em Transdisciplinaridade e Implicações da Psicologia Social leva, inicialmente, a delinear a Psicologia como implica da em um campo de saberes e poderes e sujeitada, ela própria a se fazer de acordo com os regimes de verdade dominantes. A produção da Psicologia enquanto ciência e profissão e a processualidade que marca o fazer-se da Psicologia devem ser vistas como parte das estratégias de controle social, específicas de épocas históricas e lugares particulares. Enquanto invenção sóciohistórica, a Psicologia, como dispositivo de poder-saber, pode ser considerada como dobra do social, dobra esta, dotada do poder de dobrar e 
dar formas às forças, de direcionar fluxos e constituir modos de subjetivar. O dispositivo-Psi é inseparável dos mundos que cria, efetuando-se como organismo regulado e regulador, em constante tensão entre aquilo que já lhe é histórico e sedimentado e aquilo que, enquanto atualidade, provoca-o, fere-o e o instiga à diferença e alterização.

O corpo-psi pode ser pensado como obra-aberta, organismo não homogêneo e em estado de equilíbrio instável, rodeado de múltiplas de linhas de natureza heterogênea, fraturadas e bifurcadas, que ao invés de lhe conferirem contornos definitivos, constituem-no como permanente rede de variáveis relacionadas entre si. Rede/novelo multilinear, conjunto bifurcante, uma vez que suas linhas enforquilhadas, são submetidas a variações de direção e a derivações. Bifurcar, como lembra Virgínia Kastrup, não é o mesmo que dicotomizar, pois enquanto a noção de dicotomia remete a duas realidades previamente dadas, a vocação da bifurcação é virar multiplicidade.

A multiplicidade vai se configurando na exata medida em que são operadas conexões e surgem as bifurcações, em que os fios são amarrados e as conexões cortadas ou desmanchadas (Kastrup, 2000).

Constituído de forma híbrida, o corpo-psi compõem-se pela conexão de saberes diversos, por migrações conceituais seguidas de um processo de transformação. Suas máscaras ou rostos, tendências e direções são plurais e diferem de acordo com a especificidade de suas alianças. O corpo-psi, tomado como rede complexa, é regido por processos que são imanentes aos dispositivos que o constituem, sendo sua lógica dirigida para o repúdio dos universais, do uno, do todo, do verdadeiro e posicionado a favor dos processos singulares de unificação, de totalização, de verificação, de objetivação, de subjetivação. Desapegado de referências em relação à unicidade e à verdade e posiciona-se como constructo em movimento tensionado entre passado e futuro, entre o atual e a história. O dispositivo Psi, nesta ótica, autoriza-se a habitar o vazio e o tempo, remetendo-nos ao hiato que nos separa daquilo que já não podemos dizer e daquilo que cai fora de nossa prática discursiva. Seu lugar já não coincide com o Mesmo e Idêntico, com o significado já narrado e representado. A diferença torna-se sua busca e sua recompensa, possibilitando o despreendimento de continuidades, identidades e teleologias transcendentais. O movimento de desterritorialização do dispositivo Psi, evidenciado na contemporaneidade, "estabelece que somos diferença, que nossa razão é a diferença dos discursos, nossa história a diferença dos tempos, nosso eu a diferença das máscaras" (Foucault, in: Deleuze, 1990:160).

Se tomarmos, pois, a Psicologia Social como um corpo científico que, conforme afirma Michel Serres, "corre e flutua sobre uma rede múltipla e complexa, de caminhos acavalados e entrecruzados em nós, picos ou encruzilhadas, ponto de intercâmbio nos quais se bifurcam uma ou várias vias", podemos concebê-la como um tecido flutuante composto por "uma multiplicidade de tempos diferentes, de disciplinas diversas, de idéias da ciência, de grupos, de instituições, de capitais, de homens, em acordo ou em conflito, de máquinas e objetos, de previsões e acasos imprevistos...". Não atribuída à invenção de um sujeito, que funcionaria como o centro do processo, a Psicologia é inventada no campo de certas práticas, constituindo-se como trama na qual os aspectos epistemológicos, financeiros, políticos, comerciais, teóricos e conceituais se mesclam sem privilégio de posição hierárquica de uns em relação aos outros. De sua capacidade de conectar-se, compondo-se como saber plural, quanto a métodos como quanto a objetos e problematizações, a Psicologia transpõe suas próprias fronteiras disciplinares, "sai de si, colocando-se para fora", constituindo certos momentos de momentos de suspensão em que nos perguntamos se o que estamos fazendo é ainda psicologia. Nesses pontos de indiscernimento é que se constituem os espaços de invenção de novos caminhos. Parece-me que estamos vivendo, hoje, a duração desse momento de suspensão, nutrido pelo ainda irrepresentável e indiscernível. Como diria Eugen Bavcar quando toma o espaço das trevas como aquilo que é encontrado na primeira manhã do mundo. Para este autor, as trevas condicionam a instauração da luz, sendo o quadrado negro de Malevitch uma ilustração perfeita do que é denominado esquecimento estético, a partir do qual antecipa-se uma superação.

O salvamento do sujeito criador permanece possível enquanto ele pode se colocar em face do obscuro, fazendo das trevas o seu objeto, o seu complemento, e não um inimigo a ser excluído... (Bavcar, 1994:462).

Os momentos de indiscernimento, hesitação, suspensão podem ser vistos, tal como quadro de Malevitch, como um grito contra o mundo em 
que tudo se torna intercambiável. Pode ser visto como a esperança de um olhar para além do banal...

Falo, aqui, agora inspirada em Luiz Antonio Fuganti, de um modo de pensar constituído como dobra do pensamento sobre si mesmo, implicandoo num combate interno de forças, combate ético que deve ultrapassar a consciência, a memória e os órgãos... Um combate para nos ultrapassarmos... para, de uma certa forma, nos esquecermos de nossas marcas, pois o entendimento não vem das marcas.

Ele procede da luminosidade própria da profundidade que brilha na superfície dos encontros (op.cit:55).

Corpo sem órgãos, campo afetivo de intensidades, pensamento sem marcas, livre da consciência...

Como podemos, a partir de então, discutir a questão da transdisciplinaridade na Psicologia Social? Parece-me importante assinalar que o fato de caracterizarmos o corpopsi como constituído por uma rede de intercessores, não significa dotá-lo de uma inerente capacidade de operar em termos cooperativos. Como nos aponta Baremblitt, parece óbvio que as diversas ciências não foram produzidas simultaneamente, sendo notório que umas tenham sido pré-requisito para a produção de outras que se seguiram, sendo que a aparição e o desenvolvimento das subsequentes reverteram sobre o das precedentes. Da mesma forma, pode-se reconhecer que apesar da existência de distinções entre as diferentes disciplinas, é possível encontrar entre elas traços comuns. Constata-se, pois, que o universo das ciências é marcado por importações, redefinições e refundações de recursos teóricometodológico-técnicos e que essas relações podem ser de articulação e sinergismo, mas também de confrontação, concorrência e mútuo atravessamento. As ciências constituídas operam, portanto, através de uma autonomia relativa, sendo articuladas por uma espécie de organizador (paradigma) que define um modo do saber predominante em dado período. Definindo-se por seu objeto formal abstrato e por seus fundamentos, cada disciplina demarca assim o seu território e sua forma específica de intervenção. Contudo, na atualidade, emerge uma tendência a se constituir objetos localizados na confluência de várias disciplinas, como é o caso da saúde mental e da subjetividade e cujo entendimento será tanto menos lesivo se privilegiar a complexidade de que se constituem. Desta forma, tudo levaria a pensar que o grau de cooperação interdisciplinar deveria predominar nas práticas científicas e profissionais. Não é, contudo, o que se observa.

As referências de Eduardo Mourão Vasconcelos demonstram a utilidade do conceito da transdisciplinaridade no contexto da desinstitucionalização em saúde mental e das repercussões nos saberes envolvidos na Área. Considerando a existência de diversos níveis de prática interdisciplinar, o autor leva em conta os graus sucessivos de cooperação e de coordenação entre as diversas disciplinas que compõem um campo de conhecimento e de práticas. A interdisciplinaridade pressupõe uma tendência à horizontalização das relações de poder entre os campos disciplinares implicados, reciprocidade entre os mesmos e enriquecimento mútuo.

Exige a identificação de uma problemática comum com o levantamento de uma axiomática teórica e/ou política básica e de uma plataforma de conjunto, colocando-se em comum os princípios e os conceitos fundamentais, esforçando-se para uma decodificação recíproca da significação, das diferenças e convergências desses conceitos, e desta forma gerando uma fecundação e aprendizagem mútua, que não se efetua por simples adição ou mistura. Mas por uma recombinação dos elementos internos. (...) As práticas interdisciplinares autênticas tendem, quando prolongadas no tempo, para a criação de campos de saber ou disciplinares novos (Vasconcelos, s/d: 8).

A transdiscilinaridade implica, portanto, em uma radicalização da interdisciplinaridade, com a criação de um campo teórico, operacional ou disciplinar de tipo novo ou mais amplo.

A transdisciplinaridade, pois, pode ser colocada como desafio às práticas-psi, visto que se trata de um modo de estruturar relações entre saberes e poderes, dos campos distintos ou mesmo de segmentos do próprio campo, não se colocando como efeito acabado e definitivo, mas como processualidade de um modo de produção do conhecimento. Trata-se de um novo paradigma que propõe a desconstrução dos campos organizados e instituídos, a formulação de novas perguntas e de novas problematizações, a ampliação do foco de abordagem e a ruptura com as delimitações dos saberes tradicionais. Busca uma nova recomposição de conhecimentos sustentados sobre um conjunto de rupturas e novas premissas. $\mathrm{Na}$ medida em que transpomos os limites de nossa disciplina, através de práticas como 
as recomendadas por Deleuze e Guattari que dizem para aqueles que querem fazer Psicologia: aprenda história, espolie a biblioteca do arqueólogo, do etnólogo, do economista, empanturre-se de literatura e arte... Isto significa dizer, que fazer Psicologia não implica num exclusivo enquadramento conceitual e teórico, estando tal possibilidade inscrita em soluções não necessariamente de teor científico, pertencentes aos diversos campos onde pulsa vida e nos quais se distende e processa a produção do desejo e da subjetividade.

Se considerarmos o conteúdo político e ético do que estou chamando de graus de cooperação científica, cooperação essa que se vê radicalizada no modo de saber-fazer transdiscilinar, torna-se forçoso reconhecer que a Psicologia Social, devido às suas problematizações, revela-se como campo fértil para operações de hibridização, estando aberta, hoje, às intensidades oriundas do processo de crítica que emerge do campo das práticas sociais, cujo sentido extrapolam e superam a capacidade científica de atribuir significados.

Se concordarmos, então, que os discursos Psi incumbem-se, juntamente com outras disciplinas científicas, da produção de "formas de saber que definem e determinam quais condutas podem e devem ser governadas, que circunscrevem aquilo que pode ser pensado sobre essas condutas e que prescrevem os melhores meios para torná-las governáveis", e se os pensarmos, pois, juntamente com Foucault (1987), como práticas que formam sistematicamente os objetos de que falam e não como meros elementos significantes que apenas remetem a conteúdos ou a representações, passamos a considerar que a luta pela transformação dos modos de saber da Psicologia implica-se propriamente com a luta pela mudança nos regimes que sustentam a subjetivação. A desinstitucionalização da Psicologia associa-se permanentemente aos modos pelos quais cooperamos pela desterritorialização dos modos vigentes de produção do saber, do poder e da subjetividade. Os discursos Psi podem ser comparáveis a máquinas de fazer ver e fazer falar, sendo dotados da capacidade de produzir seus próprios regimes de visibilidade e enunciação, não existindo objetos e sujeitos que não sejam efeitos de sua imanência. Como nos diz Deleuze (1999:155),

visibilidade aqui não se refere a uma luz que ilumina objetos preexistentes; está feita de linhas de luz que formam figuras variáveis e inseparáveis desde ou aquele dispositivo. Cada dispositivo tem seu regime de luz, a maneira como esta cai, se esfuma, se difunde, ao distribuir o visível e o invisível, ao fazer nascer ou desaparecer o objeto que não existe sem ela.

Avizinhemo-nos, pois, das trevas e dos indiscernimentos propostos pela nossa atual contemporaneidade. Tornemos úteis as indecisões que as inúmeras bifurcações propõem, dotemo-nos de valores éticos importantes para potencializar relações que produzam bons encontros, façamo-nos relativos, sem nos pretender insignificantes, estejamos prontos para derivar para a nossa outredade, individual e coletiva, quando assim as confluências convidarem. Aceitemos que há escolhas que o pensamento pode realizar na construção de novos sentidos. Elas, contudo, não são absolutas e definitivas, tampouco nos são dadas a priori, tornando-se realizadas apenas se nós as concretizarmos e as produzirmos. Que possamos fazer falar, desde nosso trabalho na Psicologia Social, a própria outredade da Psicologia, que poderá inclusive tomar-se nãofamiliar aos psicólogos apegados à identidade. Temos uma arma de guerra na mão. Nada nos garante a vitória, Apenas sei que não estamos na guerra desprotegidos e desarmados. Lutemos, pois!

\section{Referências bibliográficas:}

BAREMBLITT, Gregório. Das virtudes teologais, das ciências e das loucuras. In: Saudeloucura, n. 2. São Paulo: Hucitec, 1990.

BAVCAR, Eugen. A luz e o cego. In: Bavcar, E. e outros. Artepensamento. São Paulo: Cia. das Letras, 1994.

DELEUZE, Gilles. Qué es un dispositivo? In: Deleuze, G. e outros.

Michel Foucault, filósofo. Barcelona: Editorial Gedisa, 1990.

FUGANTI, Luiz Antonio. Saúde, Desejo e Pensamento. In: Saúde loucura, n. 2. São Paulo: Hucitec, 1990.

KASTRUP, Virginia. A psicologia na rede e os novos intercessores. In: Fonseca, Tania Mara Galli e Deise Juliana Francisco (orgs.). Formas de ser e habitar a contemporaneidade. Porto Alegre: Editora UFRGS, 2000.

VASCONCELOS, Eduardo Mourão. Desinstitucionalização e interdisciplinaridade em saúde mental. Texto digitado. s/d. 


\section{Bibliografia}

BACHELARD, G (1993). A poética do espaço. São Paulo: Martins Fontes, 1993.

CAPRA, E (1997). A teia da vida. São Paulo: Cultrix.

FREIRE, P.(1982) Extensão ou comunicação. Rio de Janeiro: Paz e Terra.

FREITAS, M. E Q. (1998) Psicologia reflexões (im)pertinentes. São Paulo: Casa do psicólogo.

MELUCCI, A (1996) The playing self -person and meaning in the planetary society. Cambridge cultural social studies.

(1989). Um objetivo para os movimentos sociais? São Paulo: Lua Nova.

MORIN, E. (1999). Amor, poesia, sabedoria. Rio de Janeiro: Bertrand Brasil.

PESSANHA, J.A .M. (1992). Bachelard e Monet: o olho e a mão. In: NOVAES, A. O Olhar. São Paulo: Cia das Letras

QUINTAL, M. E E (1998). Novas práticas e velhos olhares em psicologia Comunitária: uma conciliação possível? In: SOUZA, L; QUINTAL, M. E F; RODRIGUES, M.M.P. (orgs). Psicologia reflexões (im)pertinentes. São Paulo: casa do psicólogo.

RESTREPO. L.c. (2000). O direito à ternura. Petrópolis: Vozes. SANTOS, B. S. Um discurso sobre as ciências. Edições Afrontamento.

TORO, R. A. "Identidade”. In: GÓIS, C.W. de L. (org.) (1991) Coletânea de textos de Biodança. Fortaleza, Ed. AL.AB.

TOURAINE, A (1998). Poderemos viver juntos?

\section{PARTE II - GRUPOS DE TRABALHO}

\section{Pesquisa em Psicologia Social: de onde viemos e para onde vamos}

Neuza M. F. Guareschi ${ }^{1}$

Os encontros da Associação Brasileira de Psicologia Social ABRAPSO, sejam eles os nacionais ou os regionais, são sempre momentos de se rever conceitos, aprender novas teorias, mas principalmente os momentos de se conhecer novas pesquisas que estão sendo desenvolvidas na área da Psicologia Social. O VIII Encontro da Regional Sul da ABRAPSO - Santa Maria, RS - não foi diferente. No que se refere aos encontros regionais, foi o primeiro em que, na organização dos grupos de trabalho, havia três grupos organizados para discutir o tema Pesquisa em Psicologia Social. Como coordenadora de um desses grupos que debateu algumas das diferentes formas de se fazer pesquisa em Psicologia Social, fui encarregada de escrever um texto que relatasse, na medida do possível, a discussão que ocorreu com esse grupo. Assim, este texto objetiva elaborar uma discussão, pontuando algumas questões teóricas e metodológicas em relação a um desses grupos, que durante o encontro mencionado acima apresentou e discutiu algumas pesquisas que estão sendo realizadas nessa área.

Os temas das em pesquisas em Psicologia Social apresentados nesse grupo, abrangeram aspectos teóricos e metodológicos relacionados as seguintes questões: relações de gênero e mídia; masculinidade, vida doméstica e opressão; sexualidade, prostituição e representações sociais; histórias e construções de laços comunitários bem como estratégias e organizações em comunidades populares; epistemologia em Psicologia e implicações na prática profissional e pesquisa em Psicologia Social e o campo dos Estudos Culturais. ${ }^{2}$

${ }^{1}$ Professora Pesquisadora do Programa de Pós-Graduação em Psicologia - Faculdade de Psicologia PUCRS, Coordenadora do grupo de pesquisa: Estudos Culturais, identidades/ diferenças e Teorias Contemporâneas.

${ }^{2}$ A referência completa com os títulos, autores e autoras e resumos dos trabalhos citados acima encontram-se publicados nos anais do VIII Encontro Regional Sul - Associação Brasileira de Psicologia Social - ABRAPSO. Psicologia Social: Estratégias, Políticas Implicações. 
Se retomarmos um pouco a história da Psicologia Social no Brasil, veremos que esta começa a mudar, ou melhor, a se fundamentar em outro paradigma no final da década de 70 , na mesma época em que também começa a história da ABRAPSO. Esse dado histórico é importante porque foi, e está sendo através, principalmente, dos encontros dessa Associação que conseguimos divulgar e multiplicar a produção de conhecimento da Psicologia Social crítica, fundamentada em abordagens teóricas e epistemológicas que se colocam em oposição ao modelo de Psicologia Social Americana, ${ }^{3}$ baseada nos pressupostos do experimentalismo da relação causa/efeito. Calcada nos pressupostos do positivismo, a Psicologia Social Americana considera como ciência, ou como um trabalho científico, a metodologia que ostentava como seus principais elementos a objetividade, a experimentação/ comprovação, a neutralidade (separação entre sujeito e objeto) e a generalização. O objetivo, dentro dessa abordagem de pesquisa, é o de chegar a uma dedução lógica sobre os objetos que se estuda, para então poder concluir como estes podem, ou não, influenciar, ou serem influenciados, pelos comportamentos dos indivíduos.

A Psicologia Social crítica surge, então, trazendo como um dos seus principais pressupostos de pesquisa o de mostrar a falsa neutralidade do experimentalismo e o de buscar desenvolver uma produção de conhecimento em que o sujeito seja um agente ativo dessa produção mostrando, portanto, que não há separação entre sujeito e objeto e pesquisador/pesquisado. A Psicologia Social crítica começou a se preocupar também em abarcar, em suas questões de pesquisas, aspectos relacionados com o ser humano na contemporaneidade, ou seja, em priorizar em suas investigações os contextos históricos, sociais, econômicos e culturais dos sujeitos pesquisados. Isso aconteceu, por exemplo, quando alguns teóricos da área começaram a rever os caminhos metodológicos que a pesquisa em Psicologia Social tinha percorrido e buscar em áreas vizinhas, como a da Sociologia, Antropologia e Educação, outras abordagens e métodos de investigação.

Sabemos que as pesquisas, dentro das diferentes áreas da ciência, assinalam o percurso da construção do conhecimento que vem sendo produzido. Contudo, e especialmente na área das ciências sociais e humanas, nem sempre os/as pesquisadores/as têm consciência de todos os

\footnotetext{
${ }^{3}$ Quando nos referimos a Psicologia 50cial Americana estamos no remetendo a Psicologia Social dos Estados Unidos.
} 87 aspectos que envolvem esse percurso. Um dos mais importantes aspectos desse caminhar é sem dúvida o do método de pesquisa. Além de o método representar as questões teóricas e metodológicas que norteiam o pensamento do pesquisador/a, ele evidencia também de que forma as preocupações sociais são expostas no estudo e qual perspectiva política, frente à ciência e à sociedade, é adotada por quem desenvolve a pesquisa.

Se adotarmos a perspectiva de que a ciência é uma prática social, isto significa dizer que a ciência é uma produção histórica e cultural que está permanentemente criando e se recriando a ela própria. Isto também quer dizer que a ciência não é absoluta e, portanto, não possui verdades, mas está continuamente em busca da compreensão do ser humano nos diferentes contextos que envolvem suas interações sociais. Assim, a Psicologia Social crítica deixou para traz os métodos experimentais dedutivos que haviam produzido os conhecimentos dessa área da Psicologia até então, e se lançou a novos desafios metodológicos na área de pesquisa que têm sido inovados e transformados continuamente.

Podemos citar como uma das formas de pesquisa que iniciou essa relação de novas abordagens metodológicas a pesquisa participante e pesquisa ação. Temos como exemplo da utilização dessa metodologia na área da Psicologia Social crítica o respeitável trabalho de Bader Sawaia ${ }^{4}$ em sua tese de doutoramento. A metodologia participante/ação se fundamenta nos princípios do materialismo histórico, tendo a hermenêutica dialética como sua principal ferramenta de análise. Essa abordagem filosófica materialismo histórico - junto com a teoria interacionista de Vigotski, foi também o que fundamentou a discussão teórica e metodológica que a Psicologia Social passou a fazer sobre alguns de seus tradicionais conceitos como: comportamento, identidade, pensamento, linguagem, consciência, e a gerar um debate sobre o papel de algumas das instituições sociais na sociedade e na construção dos indivíduos, entendidos aqui como sujeitos históricos sociais, como a família, a escola, o trabalho, a comunicação social, etc,. Os trabalhos de Silvia Lane, Vanderlei Codo, Antonio Ciampa, Pedrinho Guareschi, são alguns dos que podem ilustrar esse novo debate na história da Psicologia Social.

\footnotetext{
${ }^{4}$ Sawaia, 1987.
} 
Outras tradições filosóficas também passaram a fazer parte dos métodos de investigação na Psicologia Social. A abordagem fenomenológica foi trazida para a Psicologia Social como uma metodologia que busca compreender o significado que os acontecimentos e as interações possuem para as pessoas no seu cotidiano, ou em situações particulares. A fenomenologia enfatiza a compreensão e explicação do fenômeno dada pelas pessoas através de seus componentes subjetivos. Compatível com a perspectiva fenomenológica, o interacionismo simbólico visa compreender como as pessoas interpretam suas experiências, situações e acontecimentos através das mediações que se estabelecem nas suas interações sociais. Outros enfoques metodológicos que privilegiam a cultura como a etnografia e a etnometodologia foram pouco utilizados nas pesquisas em Psicologia Social. A explicação dos comportamentos pelos diferentes contextos culturais, no caso da etnografia, e o modo como as pessoas percebem, descrevem e explicam o mundo cultural em que vivem, no caso da etnometodologia, pode contribuir enormemente para a pesquisa em Psicologia Social que visa compreender o ser humano por inteiro na produção de suas relações sociais e históricas.

A Psicologia Social crítica trouxe, imbuída em seus princípios epistemológicos, uma concepção histórico-social de ser humano, compreendido como produto e produtor de suas relações sociais e de um conceito de ciência como uma prática social, o qual defende que conhecimento é produzido nas relações concretas que as pessoas estabelecem dentro dos grupos sociais em que vivem na sociedade. Embora a noção crítica e progressista que envolve essas concepções de ser humano e de ciência citadas acima, muitos trabalhos em pesquisa que se colocam como pertencendo à Psicologia Social crítica, desfilam em seus procedimentos metodológicos usos não só da linguagem, mas também de técnicas positivistas e funcionalistas que são incoerentes epistemologicamente com esse conceito de ser humano e com essa concepção de ciência. Como exemplo disso, podemos citar a utilização de instrumentos como testes e questionários, que mantêm a separaçãc entre sujeito e objeto, e interpretam as respostas das pessoas desconsiderando seus lugares históricos e culturais. Citaria ainda, a utilização do método de análise de conteúdo, que no seu trabalho de compreensão dos dados dissocia em categorias excludentes a linguagem, a história, as relações sociais e os diferentes contextos das pessoas.
Outros trabalhos pregam, também, o uso indiferenciado dos métodos qualitativos e quantitativos, ou a superação do debate entre essas duas abordagens. Não se trata de discutir, ou de iniciar o debate sobre as diferenças entre os métodos; os dois são geradores de dados e cada qual se propõe a atender aos objetivos específicos de sua pesquisa. Entretanto, trata-se sim de discutir as diferenças epistemológicas e ontológicas sobre as concepções de ser humano, de realidade e de ciência em que cada método se fundamenta.

Para o paradigma científico tradicional da modernidade, essa diferença ou incompatibilidade entre esses dois métodos, não ocorre, uma vez que o objeto permanece separado do pesquisador. Ainda que esses interajam, como propõem os estudos qualitativos, em muitas pesquisas dessa área o pesquisador e objeto se colocam em instâncias separadas. Contrapondo a isso, a perspectiva de ciência emergente ${ }^{5}$ questiona essa dicotomia e propõe a impossibilidade de separação entre ambos. Essa perspectiva de ciência também estabelece que os dois se fundam mutuamente: o pesquisador cria seu objeto de estudo, estando fatalmente entrelaçado a ele. Portanto, a discussão entre abordagem de pesquisa qualitativa e quantitativa não está de forma alguma superada. Ao contrário, trata-se de uma discussão epistemológica que apenas começa:

Recentemente, emergiram, na área de pesquisa em Psicologia Social, enfoques teórico-metodológicos que vieram redimensionar a discussão, tanto em relação a questões epistemológicas, quanto em relação a aspectos da práxis da Psicologia Social. Estamos falando aqui da temia das Representações Sociais e da abordagem do Construcionismo Social. Primeiro foi a vez dos trabalhos na área das Representações Sociais que se propuseram, através de grupos focais e entrevistas, re-discutir a produção de conhecimentos na Psicologia Social, partindo do ponto de vista do conhecimento que é produzido e elaborado no senso comum, no cotidiano dos contextos culturais e sociais das comunidades em que as pessoas vivem. O trabalho de pesquisa em Representações Sociais levou a Psicologia Social inserir-se em temas da ciência que até então estavam negligenciados da Psicologia Social, ou eram abordados por outras áreas da Psicologia de

${ }^{5}$ Por ciência emergente, quero me referir ao estágio atual de discussão epistemológica, onde postula-se uma divergência e crítica aos ideais iluministas e positivistas da ciência moderna. Para uma leitura mais aprofundada do tema, vide Prigogine, 1997. 
forma "psicologizada", isto é, de forma a-política, a-histórica e individualizada. Dentre esses temas desenvolveram-se trabalhos sobre ideologias, saúde pública, doenças mentais e sexuais, educação, esferas pública e privada da sociedade, identidades, relações de gênero, raça, etnias, classe social e vários tópicos que envolvem o tema da exclusão social.

Atualmente, o Construcionismo Social vem marcar um novo paradigma na Psicologia Social. Mesmo que as pesquisas em Representações Sociais tenham levado a Psicologia Social a produzir conhecimentos novos e abordar temas de forma diferente como colocado acima, entendemos que essa teoria ainda se situa num paradigma das teorias sociais críticas. Essas teorias tomam como fundamentais questões como: os elementos estruturais da sociedade, a postura crítica e denunciativa em relação aos grupos dominantes, a análise de fenômenos da contemporaneidade com teorias e concepções de sujeito da modernidade e uma idéia de subjetividade humana dada como algo por inteiro e não como processos interrompidos e fluidos.

Por incluir em seu corpo teórico e metodológico as práticas discursivas e a produção de sentidos no cotidiano, devese dizer que o Construcionismo Social inicia na Psicologia social uma virada linguística. ${ }^{6}$ O Construcionismo Social concebe tanto o sujeito como o objeto como construções histórico-sociais, estabelece uma crítica à idéia representacionista do conhecimento e da objetividade, problematizando aspectos sobre a realidade e o sujeito. Pois, através de questões da linguagem, o Construcionismo Social $^{7}$ incorpora, em parte, a perspectiva linguística do estruturalismo e a discussão das práticas discursivas e de discurso do pós-estruturalismo nas análises sobre a produção de sentidos no cotidiano dentro da sua abordagem teóricometodológica.

Uma das marcas básicas da Psicologia social, tomada como um projeto mais amplo, é a importância que esta deve dar ao contexto onde se dá a ação social, ao foco localizado e historicamente específico, à atenção

\footnotetext{
${ }^{6}$ Ao fazer referência a Virada Linguistica, cabe aludir o que Veiga-Neto (1996) propõe: “O que dizemos sobre as coisas nem são as próprias coisas (como imagina o pensamento mágico), nem são uma representação das coisas (como imagina o pensamento moderno); ao falarmos sobre as coisas nos as constituímos".

Para melhor compreensão sobre os pressupostos teóricos e metodológicos do Construcionismo Social consultar o trabalho organizado por SPINK, 1999.
}

às especificidades e particularidades articuladas a uma conjuntura histórica determinada, produzindo, então, pesquisas e teorias engajadas nas práticas e lutas sociais e nas diferenças culturais que constituem e são constituídas através das relações das pessoas. O interesse central da pesquisa dentro da área da Psicologia Social é perceber as intersecções entre as estruturas sociais, os grupos sociais, a cultura, a história e as relações que as pessoas constroem e passam a ser construídas por elas. Tomando como primordial essas questões para a Psicologia Social, consideramos que os Estudos Culturais $^{8}$ possam acrescentar algumas outras questões ao debate sobre pesquisa em Psicologia Sociat fundamentalmente por se tratar de um campo de estudos transdisciplinares.

Os Estudos Culturais utilizam todos os campos que forem necessários para produzirem o conhecimento exigido por um projeto particular. Por isso, Johnson (1986) coloca os Estudos Culturais como campo de diferentes saberes para se produzir conhecimento útil sobre a cultura humana. Desses campos de saberes das últimas épocas, tem se aproveitado desde o marxismo e o feminismo passando pela psicanálise até o pós-estruturalismo e o pós-modernismo.

Os Estudos Culturais devem ser vistos sob dois pontos de vista: político, como a tentativa de constituição de um projeto político e teórico, como a intenção de construir um novo campo de estudos. O primeiro ponto de vista é sinônimo de "correção política", podendo ser identificado como a política cultural dos vários movimentos sociais da época de seu surgimento. O segundo resulta da insatisfação com os limites de algumas disciplinas, propondo, então, a transdiscip linaridade.

Esta característica particular dos Estudos Culturais, ou seja, o caráter transdisciplinar, faz com que sua metodologia seja ambígua. Definida como uma bricolage, a metodologia, no campo dos Estudos Culturais, constrói os objetos de estudo a partir de diversos procedimentos metodológicos. Assim também, a postura do/a pesquisador/a, chamado/a de pesquisador-bricoleur, é caracterizada por fazer uso de um referencial teórico de análise e

${ }^{8}$ Outras discussões sobre o campo do conhecimentodos Estudos Culturais e seus enfoques teóricos e metodológicos podem ser encontrados nos seguintes trabalhos: ESCOSTEGUY, 2000; ESCOSTEGUY, 1999; HALL, 1990; HALL, 1980; JOHNSON, 1986; NETSON, 1995. 
compreensão do seu objeto de estudos a partir diferentes disciplinas, requerendo do/a pesquisador/a uma destreza teórica particular, por utilizar diferentes procedimentos metodológicos e intersectar várias áreas do conhecimento dentro das ciências sociais.

Meyer (1999) acrescenta que Stuart Hall enfatiza que no contexto dos Estudos Culturais o referencial pós-estruturalista de Foucault e Derrida tem dado grande contribuição na questão metodológica. Está sendo permitido analisar como os sujeitos compreendem a si mesmos dentro da cultura e como o conhecimento acerca do social, do indivíduo corporificado e dos significados que estes compartilham em grupos/comunidades específicas são produzidos nos diferentes momentos históricos.

Uma abordagem que, mesmo pressupondo a produção discursiva do social e dos sujeitos, não implica a negação da existência material de pessoas, coisas e eventos, mas que sustenta que elas não têm, em si, significados fixos, uma vez que elas significam e se tornam verdadeiras somente dentro, ou pela articulação, de determinados discursos enraizados em contextos particulares e localizados. É o discurso, e não o sujeito ou a instituição social que o assumem, que produz conhecimento. Estes (sujeitos e/ou instituições) podem estar produzindo textos particulares, mas estão operando dentro dos regimes de verdade de um período e cultura particulares (Meyer, 1999, p.59).

Embora possa ser dito que desde seu início os estudos culturais tenham tido uma inflexão interdisciplinar, a proposta construída pelos estudos culturais é singular. Essa tradição propõe um olhar interdisciplinar, ou melhor, transdisciplinar, que entende os processos culturais e sociais como interdependentes e não como fenômeno isolado. Essa interdependência caracteriza uma relação dinâmica com outras esferas. Os estudos culturais reconhecem a capacidade dos sujeitos sociais de manifestar diferentes práticas simbólicas, situadas em um determinado contexto histórico. Isto significa deslocar do foco das análises em pesquisas de Psicologia Social, como, por exemplo, sobre as relações de dominação, da reprodução e da ideologia para o foco dos efeitos do discurso. A concepção de discurso aumenta a possibilidade de entender a realidade na qual as pessoas constroem suas relações, no sentido de percebermos que essas não são somente interpeladas por uma ideologia dominante, mas também resistem a ela e se mobilizam produzindo novos sentidos e buscando mudanças. O discurso, como produção de sentidos, é entendido aqui como social e historicamente construído, passa a ser a própria ação do sujeito. Não só a fala, mas a linguagem, na sua leitura semiótica, é ação.

A perspectiva em pesquisa, dentro do campo dos Estudos Culturais, apresenta dois objetivos principais: primeiro, insistir que todas as relações sociais são influenciadas por relações de poder, que devem ser entendidas mediante análise das interpretações que as pessoas fazem das suas próprias situações. Segundo, que toda investigação se baseia numa perspectiva teórica interdisciplinar/transdisciplinar em relação ao comportamento humano e social. Deste modo, não é possível desenvolver o processo de análise de forma indutiva; todo processo de compreensão do pesquisador em relação ao objeto de estudo demonstra as convicções teóricas e políticas do pesquisador que devem ser continuamente transformados pelas experiências vividas pelos sujeitos que investiga.

\section{Bibliografia}

ESCOSTEGUY, Ana Carolina. Um olhar sobre os estudos culturais latinoamericanos. Texto apresentado na leitura pública no COMPÓSPUCRS, Porto Alegre, 2000.

ESCOSTEGUY, Ana Carolina. Estudos Culturais: uma introdução. In: DA SILVA, Tomaz Tadeu (org.) O que é, afinal, Estudos Culturais? Belo Horizonte: Autêntica, 1999.

HALL, Stuart. The emergence of cultural studies and the crisis of the humaniries. October, 53,1990: 11-90.

HALL, Stuart. Cultural Studies and the Centre: some problematics and problems. In: HALL, S., HOBSON, D., LOWE, A., e WILLIS, P. Culture, media, language working papers in cultural studies, 19721979. Londres:

Routledge e Centre for Contemporary Cultural Studies/ University of Birmingham, 1980.

JOHNSON, Richard. The story so far: And further transformations. In. D. Punter (org.). Introducion to Contemporary Cultural Studies. Londres, Longman, 1986. 
MEYER, Dagmar E. E. Identidades Traduzidas: cultura e docência teutobrasileiro-evangélica no Rio Grande do Sul. Porto Alegre: UFRGS, 1999. Dissertação (Doutorado em Educação), Faculdade de Educação, Universidade Federal do Rio Grande do Sul, 1999.

NETSON, P. A. C. Estudos Culturais: uma introdução. In Thomaz Tadeu da Silva (org.) Alienígenas na sala de aula. Petrópolis, RJ: Vozes, 1995.

PRIGOGINE, L La Fin de la Certitude. In Mendes, C. (org); Representation et Complexité. Rio de Janeiro: Educ/ Unesco, 1997.

SAWAIA, B. B. A Consciência em Construção no Trabalho de Construção da Existência. Tese de Doutorado não publicada em Psicologia Social. PUCSP. São Paulo, 1987.

SPINK, M. J. Práticas Discursivas e Produção de Sentidos no Cotidiano: Aproximações Teóricas e Metodológicas. São Paulo: Cortez Editor, 1999.

VEIGA-NETO, A. Olhares... In: Costa, M. V. (org.) Caminhos Investigativos. Porto Alegre: Editora Mediação, 1996.

\section{Por uma Psicologia que se diz social: contemporaneidade, tecnologia e subjetividades}

Deise Juliana Francisco
Me vejo no que vejo
Como entrar por meus olhos
Em um olho mais límpido
Me olha o que eu olho
É minha criação
Isto que vejo
Perceber é conceber
Águas de pensamentos
Sou a criatura
Do que vejo

O presente escrito tem seu motivo advindo da coordenação de um grupo de pesquisadores que traziam suas contribuições a um Grupo de Trabalho da ABRAPSO-SUL, realizado em Santa Maria/RS. Grupo composto por diversos olhares-fazeres em Psicologia dita social.

Não trago a pretensão de enunciar a voz da maioria do grupo, nem da minoria neste escrito. Relatar o ocorrido, nem ao menos isso. Trazer apanhados gerais, nem tanto. $\mathrm{O}$ que trago aqui são as marcas que o encontro deixou enlaçadas em mim com os ditos, com as sensações e os pensares daquele momento. "É minha criação, isto que vejo".

Os trabalhos apresentados passearam pelas temáticas da representação social, trabalho comunitário, informática educativa, enlaçadas pelas questões do trabalho. De alguma forma circundamos a questão das formas de subjetivação que estão em conjugação na contemporaneidade. Articulado a isto, a discussão sobre a implicação do fazer em Psicologia Social por parte dos/as psi e a pergunta sobre o que há de social na Psicologia Social se as pesquisas estão dentro dos muros acadêmicos. Assim, construiu-se uma crítica à produção acadêmica gestada e veiculada puramente em meio acadêmico, com uma única saída tímida tal qual um escorregão a campo (comunidade, sujeito de pesquisa), momento em que os dados serão coletados para posterior exame/diagnóstico. 
Alguns caminhos foram apontados como saída desta situação como, por exemplo, o deslocamento tanto geográfico quanto conceitual da academia para a "sociedade". Apontou-se a necessidade de contato com outras áreas do saber, inclusive com o pensar sobre as fronteiras das disciplinas e com a realização de trabalhos que desloquem o lugar da pesquisa enquanto reflexão apartada da prática social. Neste sentido, partilhamos enquanto grupo dos incômodos que historicamente a Psicologia Social têm se defrontado: relação academia/sujeitos sociais; relação teoria/prática; produção voltada para o social. Tais dicotomias marcam o lugar da produção histórico-social dos conceitos além de construir lugares para os sujeitos: "sou a criatura do que vejo".

Ao pensar no social, alguns elementos se fazem presentes na memória: organização, indivíduo, sociedade, comunidade, Estado, capitalismo, globalização, tecnologia. Tais elementos são construções, com isso quero dizer que não entendo o social enquanto evidência, algo próprio/intrínseco dos agrupamentos humanos, mas sim enquanto uma emergência histórica, relacionada a um sistema de regulações e de práticas específicas de cada sociedade (Silva, 1999). Tais formações sociais produzem territórios existenciais, encharcados de desejo. O social, assim, é o produto dos investimentos do desejo que atravessam uma determinada formação histórica.

Pensar em sujeito é pensar em sociedade, em modos de subjetivação dominantes; é pensar em produção: produtor/produzir/produto... produção de verdades. E nas relações de força presentes nesta produção de saber, nas práticas de poder que aí são gestadas, são admitidas práticas, sentires, pensares, tidas como aceitáveis ou inaceitáveis. E é sobre estes limites que trabalhamos, com a subjetividade contemporânea, como aponta Pelbart (2000, p. 13),

sob o signo desta tríplice determinação: a forma-homem historicamente esculpida, as múltiplas forças que batem à porta e põem em xeque essa mesma forma-homem, e a idéia do experimentados de si mesmo.

Assim, amplificar os pensares habituais da Psicologia Social, jogarmo-nos no campo da produção de verdades, é um caminho viável para a Psicologia dita Social, na busca de traçar alguns caminhos possíveis de mudança no olhar, no navegar... "Águas de pensamentos"...
Virilio é um pensador francês que se debruça sobre a cultura, fazendo um levantamento das tendências contemporâneas presentes na constituição das subjetividades. Suas discussões podem parecer anacrônicas, pois que tratam de fatos oriundos do período da Guerra Fria, porém, ao falarmos de tendências tais fatos tomam uma dimensão outra, sendo indicativos de algumas formas de organização humanas neste século. Neste sentido, apontam-se os tipos de relacionamento social que as tecnologias engendram relacionados com os sistemas de regulação sociais.

Podemos ter um desenho de algumas destas transformações pelo uso de formas de organização do social. Por exemplo, mudamos a cena social quando da passagem do uso da tática (arte de caçar) para a estratégia (como se defender e atacar) e daí para a bgística (preponderância dos meios, um sistema de vetores que comportam diversas instâncias da vida socialprodução, transportes, etc.). Esta última - logística - entra no campo social dissuadindo as relações, minando a economia civil (que investe agora em proteção, ou melhor, no desenvolvimento de armas), detonando a política (pois não há tempo para a reflexão e do encontro coletivo na hora $\mathrm{H}$ de decidir pelo lançamento da bomba), confundindo e descentrando homens e mulheres, colocando a responsabilidade sobre os ombros de quem sabe e de quem defende: a lógica militar.

Aqui se engendram modos de produzir, relacionar-se, fazer política, relacionar-se com a morte hibridizados com as formas tecnológicas compostas.

Muitas vezes, enquanto psicólogos e psicólogas, não nos damos conta do quanto a subjetividade está inscrita no social, incluindo aí, as tecnologias. Estas são naturalizadas, concebidas enquanto técnica "pura", dependente dos usos que podem ser feitos dela. A proposta de Virilio frente a isto é encarar o enigma da tecnologia, tendo consciência de que não controlamos o que produzimos e que, pela lógica pragmática, afastamos a produção da reflexão. Nisto constituise o trabalho epistemo-técnico. Assim, não há instrumento neutro, nem tecnologia, nem ciência, nem sujeito. Nem objetividade nem subjetividade.

Questões complexas para o campo psi que hegemonicamente se constituiu enquanto campo de intervenção e produção de indivíduos, imersos 
em uma relação bi-pessoal: “quer falar de você para mim?” Esta interrogação de Cyro Martins demarca bem a prática individualista da Psicologia.

A Psicologia Social Comunitária, com seu percurso de intervenção comunitária há muito se debate com tais concepções, na medida em que se articula com outros saberes e demandas. Com outros mundos, que muitas vezes interpelamos se é, efetivamente, um mundo psi. E o convite de tal prática é efetivamente este: suspender o "serpsi" em nome do devirqualquer-coisa, nos fluxos de uma psicologia que se diz social.

Voltando a ampliar o escopo. Um dos atravessamentos em nosso cotidiano é a velocidade. Esta é um índice a partir do qual podemos dimensionar as relações sociais, pois regula as relações, acelera o movimento, destituindo o tempo da sociedade de Bem-Estar para a sociedade da instantaneidade, do gozo do momento.

Na relação com a política, Virilío explícita a transpolítica, não mais a política da reflexão, mas a da instantaneidade, quando da automação da máquina-deguerra e a cronopolítica, a distribuição do tempo e não mais do território. No campo da sociedade, a dromocracia, sociedade regida pela lógica da corrida. No espaço, a cronografia, não mais a geografia do espaço, mas a do tempo. Na economia, a eco-logística, o direcionamento da economia à produção de destruição, com o decorrente não-desenvolvimento da economia civil.

Esta "constatação" parte da presença da aceleração do tempo desde as máquinas de guerra (de canhões, a armas, a metralhadoras, a mísseis,...) aos artefatos do cinema (câmeras,...).

A velocidade está ligada à riqueza e ao poder, no momento em que o mais veloz tem maiores condições de adquirir riqueza. Além disso, quanto mais se torna veloz, mais acelerado, mais violento e mais inconsciente esta é a face dromoscópica, da velocidade que causa o desaparecimento das formas. O movimento da velocidade chega a uma aceleração tal que acaba por exterminar o próprio tempo, instaurando uma ditadura do movimento, do impensado, do deslocamento zero na velocidade, com a inércia polar.

A política, então, se afastou de seu papel regulador, baniu de si a morte e a sociedade perdeu, desta forma, seu regulador: o míssel faz tudo sozinho, a dromocracia toma conta e a cidade é deslocada para o tempo, tempo de não pensar, de agir automaticamente, instantaneamente, reduzindo o mundo a um único lugar indistinto (pois que quando andamos rapidamente - de carro ou de avião, por exemplo - não percebemos nada, a não ser um território cinza, não é?).

Neste cenário, o que teríamos a fazer? A inércia total é uma saída. Mas há outras possíveis. Virilio aponta o trabalho epistemo-técnico, em que a surpresa tecnológica e científica é a essência da resistência. É preciso que nos perguntemos a respeito da velocidade, que a politizemos: O problema não é usar a tecnologia mas compreender que se é usado por ela. Portanto, não se tratava de usar instrumentos tecnológicos, fossem eles o que fossem - televisão, rádio livre, etc. - mas de trabalhar a essência da tecnologia em suas relações com o político (Virilio, 1984, p. 78).

Ampliando o escopo, podemos inserir a idéia de que as armas, instrumentos tecnológicos, são instrumentos de percepção, ou seja, estimulantes que provocam fenômenos químicos e neurológicos sobre órgãos do sentido e o sistema nervoso central, afetando as reações e a identificação e diferenciação dos objetos percebidos (Virilio, 1993, p. 12). Em certo ponto do texto, o autor se pergunta se a lógica da artilharia não seria a mesma do cinema: o que é iluminado é revelado (idem, 1993, p. 29). Para situar esta pergunta é necessário assinalar que o início das máquinas de visão (cinema, por exemplo) esteve atrelado a seu uso nas equipes de determinação do campo de guerra - os chamados aviões de reconhecimento. Ou seja, estas máquinas serviam como um olho que demarca, que mostra, que revela o campo para o confronto, e que, para além disso, transforma o campo com a possibilidade de congelar o tempo e deflagrar o instante. Com o passar do tempo, foi-se tornando o que demarcava onde atirar (metralhadoras que eram colocadas nas asas dos aviões acopladas a câmeras de filmagem). As próprias tecnologias cinematográficas foram desenvolvimentos realizados a partir de revólveres: a câmera cinematográfica foi precedida pelo fuzil cronofotográfico de Marey e pela metralhadora de Gatling, e no revólver de Colt. A lógica da imagem, da comunicação icônica imiscuiu-se na lógica da guerra, a partir da qual surgiu. Tal qual Dziga Vertov afirmou:

Sou um olho. Um olho mecânico. Eu, a máquina, mostro-vos o mundo de um modo como só eu posso vê-la. Liberto-me hoje e para sempre da imobilidade humana. Estou em constante movimento. 
Aproximo-me e afasto-me dos objetos. Rastejo debaixo deles. Movome colado à boca de um cavalo a correr. Caio e levanto-me juntamente com corpos que caem e se levantam. Isto sou eu, a máquina, manobrando entre movimentos caóticos, registrando um movimento após o outro, nas combinações mais complexas. Liberto dos limites de tempo e de espaço, coordeno cada um e todos os pontos do Universo, onde quer que eu queira que eles se encontrem.

O meu caminho conduz à criação duma nova percepção do mundo.

Assim explico, de uma nova forma, o mundo por vós ignorado. (1923, apud Virilio, 1993)

Se as tecnologias conformam o olhar e são por ele conformados, o interessante do trabalho é, pois, o de adentrar esta hibridização, compor um campo de implicação que está para além do desenho de um território, pois desenhos trabalham com linhas mais ou menos densas, escuras, trabalham com claro e escuro. A constituição de uma cartografia é como a captura de campos de intensidades, campo recortado por quem o faz, por quem o constrói, recorte de máquinas, olhar constituído por intensidades.

As tecnologias, desde este ponto de vista, constituem a ecologia cognitiva, em que não determinam nada. Resultam de longas cadeias intercruzadas de interpretações e requerem, elas mesmas, que sejam interpretadas, conduzidas para novos devires pela subjetividade em atos dos grupos ou dos indivíduos que tomam posse dela (Lévy, 1995, p.186). Tecnologias que se articulam com o sistema cognitivo, que moldam as idéias que temos e, além de adentrar e engendrar modos de conhecer, engendram modos de ser, de conviver, a partir do contexto em que este se dá.

Social constituído através das tecnologias construídas historicamente. Através de saberes construídos historicamente. Através de percepções construídas historicamente. Através de uma Psicologia Social construída historicamente.

Assim, deixo uma questão apontada por Nilza Silva sobre a escolha de ser psicólogo/a:

A psicologia ocidental hegemônica, no século XIX, padece de uma preocupação comum a várias ciências: desvelar a verdade do ser humano, inserindo-o nas leis que regem os fenômenos naturais. Sob a tirania da verdade necessária, o psicólogo se transforma num narrador da realidade, desinvestindo sua responsabilidade e seu compromisso no processo de produção do mundo. Este modelo de psicologia torna-se um arranjamento autoritário, no qual a verdade é desvelada e manejada por poucos para o acatamento de muitos. (http:// gama. urisan. tche. br / -psicologia/eventos/dasescolhas.htm)

\section{Referências Bibliográficas}

LÉVY, Pierre. As tecnologias da inteligência. São Paulo: Ed. 34,1995.

PELBART, Peter Pál. A vertigem por um fio: políticas da subjetividade contemporânea. São Paulo: Editora Iluminuras, 2000.

SILVA, Nilza. Das escolhas. Disponível em http:/ / gama. urisan. tche. br / psicologia / eventos / dasescelhas.htm, capturado em 20 de março de 2001

VIRILIO, Paul. Guerra e cinema. São Paulo: Editora Página Aberta, 1993.

; LOTRINGER, Sylvere. Guerra Pura: a militarização do cotidiano. São Paulo: Brasiliense, 1984. 


\section{Práticas institucionais}

Marília Veríssimo Veronese

\section{Introdução}

$\mathrm{Na}$ medida em que atribuímos sentidos às palavras, vamos encontrado os caminhos para dar-Ihes mais amplitude, e construímos ou redimensionamos novos saberes sobre seus significados. Certamente significamos muito a expressão práticas institucionais no VIII Encontro Regional da Abrapsosul, durante aquela manhã de setembro no Teatro Caixa-Preta, na UFSM.

Começaremos, aqui, indo ao dicionário para conhecermos as diferentes nuances que as palavras podem possuir, para abrirmos a discussão sobre o sentido dessas palavras, sobre o que elas geram, sobre o que elas produzem. O que seria, a princípio, instituição, instituir, praticar? No dicionário, temos:

Instituição: (...) complexo integrado por idéias, padrões de comportamento, relações inter-humanas e, muitas vezes, um equipamento material, organizados em torno de um interesse socialmente reconhecido.

Instituir: Criar, estabelecer, fundar. Declarar, nomear. Prática: Ação; (...) Realização; (...) Aplicação; (...) Exercício; (...) Habilidade; (...) Modo ou método; (...) Maneira de proceder. (Dicionários Michaelis, 1998).

A instituição é sabidamente um lugar de produção e reprodução social. Portanto, através de diferentes maneiras de realizar, exercitar, proceder e aplicar, estabelecemos, ou nomeamos, modos distintos de interação e produção humanas, os quais seriam essas instituições. Esse é o campo que a palavra prática inaugura, abre, dentro dessa discussão institucional: o de que as ações humanas, portanto sociais e historicamente colocadas, é que irão construir e organizar os interesses socialmente reconhecidos, e os objetivos dos mesmos.

Ao nos darmos conta desse poder instituinte, podemos transformar nossas práticas em ações conscientes, e dessa forma transformarmos as instituições que elas ajudam a compor. Sob a ótica da psicologia social crítica, isso seria extremamente importante para o desenvolvimento humano e suas diversas possibilidades. Isso já caracteriza uma questão política, pois os agentes sociais instauram as realidades institucionais, através de suas práticas administrativas, afetivas, interpretativas etc.

\section{Práticas e instituições: saberes e poderes}

Ao definirmos uma prática política (que se dá na família, empresa, escola, ONG, ou qualquer outra instituição), estamos exercendo um poder pessoal de transformação, reprodução, resistência... o que seja. Assim poderão definir-se novas normas (e formas) institucionais. A instituição tem esse aspecto normativo, mas tem também um espaço político de exercício de poder que, se bem administrado e ocupado, pode desvelar novas formas de "fazer" institucionais. Foi isso que observamos durante os relatos e discussões dos trabalhos realizados dentro da temática "práticas institucionais", posto que a dimensão propositiva esteve presente o tempo todo.

Universidade, Escola, Centro educacional para adolescentes em conflito com a lei, Empresas, campos da psicologia em desenvolvimento: os temas eram variados. As abordagens também podiam diferir, pois a própria Psicologia Social é ela mesma um campo híbrido, que se transforma ao longo de sua construção (feita pelas mais diversas práticas e correntes). Ao invés de totalizar categorias parciais, a psicologia social amplia-se e dialoga com outros matizes científicos. Por exemplo, é esclarecedor o texto de Jacques (1999) sobre as divergências, aproximações e intersecções entre os campos da psicologia clínica, psicologia do trabalho, psicologia institucional e a psicologia social crítica. Todas essas "psicologias" oferecem suas contribuições, e nosso desejo, no grupo, foi que elas dialogassem proficuamente.

As relações laborais podem ser abordadas sob um ponto de vista sistêmico (grande avanço sobre a teoria clássica) onde há o privilégio de um trabalho grupal resgatando o sentido de equipe, a cooperação etc., aspectos de vital importância na transformação das práticas institucionais, que incorporam elementos das ciências da educação e das práticas da administração.

A psicologia social crítica do trabalho vai buscar os possíveis daquilo que nos parece impossível: relações laborais livres do jugo da exploração, trabalhadores/as sujeitos do seu trabalho e de suas próprias vidas, 
cooperando com um sistema social mais justo (a utopia é o seu possível) e procurando desvelar as distorções comunicacionais. Para isso há que articular ensino-pesquisa-extensão universitária, como dispositivo de transformação na prática da psicologia do trabalho; há que democratizar as instituições, evitando escamotear a ideologia produtivista em ações paliativas, expondo as dificuldades e riscos reais do trabalho, para "empoderar" os trabalhadores e trabalhadoras como sujeitos de seu processo.

Essas diferentes tendências, ainda citando Jacques (1999, p. 94), estão "inscritas num contínuo vir-a-ser". O que pareceu comum ao grupo foi a idéia de que a instituição e o ser humano engendram fenômenos complexos e não podem ser vistos a partir de um único sistema de explicação teórico, metodológico ou ideológico. Não obscurecendo, negando ou eufemizando as diferenças entre os campos, conseguiremos um diálogo mais profícuo e propulsor de uma psicologia social mais rica e inclusiva.

Para nós pareceu também que cada sujeito, grupo e comunidade precisa construir seus próprios saberes, transformar e modificar suas práticas conscientemente (comportamentos mais construtivos, criativos e maduros serão consequência), através de práticas pedagógicas que promovam o exercício pleno da cidadania. Um sujeito empobrecido economicamente, ou dependente da instituição, ou subjugado em relações de dominação de gênero, classe ou raça poderá exercer plenamente sua cidadania, seus direitos? Ser é devir, nunca poderemos afirmar algo como necessário. Portanto é aí que a Psicologia, com suas especificidades (a despeito de sua imensa pluralidade), tem de contribuir. Vejamos como ajuda a compreensão o texto de Rey (1995, p.151):

$\mathrm{Si}$ viéramos la social como determinante y el individuo como determinado, como reprodutor lineal de leyes e estructuras sociales, el sistema de conocimientos se estructuraría fuera del sujeto, no siendo realmente necesaria la psicologia.

A psicologia precisa então desvelar junto com esse sujeito desejante, que se organiza em instituições, quais as práticas que comporiam um conjunto de ações libertário, que tornasse mais realizado esse mesmo sujeito.

As práticas institucionais que desejamos levam em consideração a saúde física/psíquica/social do sujeito (este etimologicamente ligado à subjetividade: portanto não é sinônimo de indivíduo, e sim de ator/dispositivo social). A nocividade dos ambientes de trabalho, estudo, convivência, precisa ser reconhecida e trabalhada. A violência da organização do trabalho que se manifesta nas instituições, necessita, para transformar-se, de muita discussão, de programas de desenvolvimento de cunho social e psicológico para gestores e trabalhadores, abordando temas considerados tabus pelas instituições (pobreza, exclusão, sofrimento, coerção etc) e que ressignifiquem as relações humanas em termos de solidariedade, auxílio mútuo, justiça e cooperação.

As instituições acadêmicas têm um papel vital neste processo: devemos insistir numa revisão no currículo acadêmico das universidades. Seria muito importante noções de filosofia, ética, abordagem humanística em relação à visão de ser humano, em todas as faculdades. As universidades também precisam proporcionar a seus alunos discussões sobre emprego, terra, nutrição e outros assuntos vitais para a saúde humana, além de abordagens mais críticas e integrativas naquilo que se refere à prevenção em saúde social. Um novo posicionamento epistemológico é exigido, para que haja possibilidade de ocupar, na instituição, o espaço de mediação na reconstrução do conhecimento, da cidadania e da emancipação dos sujeitos sociais. Esse posicionamento se caracteriza pelo tensionamento produtivo entre diferentes saberes, sobretudo (Santos, 1996). Arelação saber-poder torna-se então mais simétrica e produtora de aprendizagens e autonomia. $\mathrm{O}$ abandono das posturas defensivas, a explicitação dos modos de operação da ideologia, a criação de dispositivos de comunicação mais transparentes e uma outra forma de lidar com o poder são algumas práticas institucionais que esperamos ver e sentir em nossas instituições daqui para frente.

O poder é um conceito com múltiplas definições e abordagens, bem como a ideologia. Fazendo uma brevíssima revisão bibliográfica, podemos trazer à discussão alguns autores, dentre muitos os que contribuíram (e contribuem) para a problematização do tema.

\section{Para Thompson, poder é a}

capacidade de agir para alcançar os próprios objetivos e interesses, a capacidade de intervir no curso dos acontecimentos e suas consequências. (Thompson, 19.98, p. 75) 
Nesse sentido, aqueles que têm mais recursos de poder, como os indivíduos que ocupam posições dominantes dentro da organização, têm condições de ditar os rumos dos acontecimentos através de sua tomada de decisão, que pode se configurar como ideológica no sentido negativo, ou não; dependerá do contexto, intenções, desdobramentos etc.

Para Michel Foucault, poder é sempre relação que produz efeito. Engendra a sociedade, produzindo saberes que conduzirão os rumos da mesma através das lutas diárias dos indivíduos e grupos sociais. Aqui a questão do poder faz-se central: nas suas múltiplas ramificações, "lá onde ele se torna capilar", como diz Foucault (1988, p. 182). Está lá, permeando todas as relações, ao mesmo tempo nuclear e periférico. $\mathrm{O}$ poder como prática, como relação. Esta abordagem pode ampliar a possibilidade da compreensão da questão do poder nas relações institucionais. O poder circula, engendra a sociedade com suas cadeias e vai tecendo malhas; os saberes que nos constituem, são constituídos no poder. E ditam regimes de verdade, aos quais nos sujeitamos, em maior ou menor grau, com maior ou menor sofrimento. A própria sujeição nos compõe, enfim, afirma esse autor. Dessa forma, os regimes de verdade de cada empresa acabam compondo a própria subjetividade de seus trabalhadores - podemos pensar, se seguirmos sua ótica.

No livro Microfísica do Poder, Foucault coloca a necessidade de analisar como, nas células elementares da sociedade (como a família, a escola etc), se processa a legi timação dos regimes de verdade através das proibições, vetos, repressão e exclusão. Ora, num núcleo elementar de trabalho, ou seja, numa empresa (ou qualquer instituição), tais situações prestam-se sobremaneira à essa análise.

Enquanto Thompson se pergunta por que e como, em determinadas situações, o sentido das formas simbólicas é utilizado para sustentar relações de dominação, Foucault pergunta sob outro enfoque - parte de baixo para cima, do núcleo básico familiar para o aparelho do Estado, enquanto o outro autor transita no sentido inverso - relações assimétricas de dominação. Para Foucault, não existe a assimetria, e sim técnicas de poder que criam dispositivos de práticas sociais.

Se tomarmos as duas abordagens não como antitéticas, mas como complementares, poderão estar criando saberes no seu "embate". Ainda na obra entitulada Microfísica do Poder, encontram-se elementos que reforçam esta sensação descrita no parágrafo acima. $\mathrm{O}$ autor não nega a existência da Ideologia; antes, crê que ela existe e acompanha a educação, o poder monárquico, a democracia etc... mas que o fundamental, para ele, não é o seu estudo, mas sim o das: “...formas de sujeição, os usos e as conexões da sujeição pelos sistemas locais e os dispositivos estratégicos” (p.186). A questão da dominação é fundamental para ele; não como construção ideológica, mas sim como circulação de saberes e poderes em mecanismos sutis, permeando as relações humanas em todos os níveis.

Também podemos buscar outras definições e abordagens do conceito de poder, para melhor entendermos essa problemática, através de outros/as teóricos/as. Por exemplo, Rosa Krausz (1991) divide o poder em dois tipos: contextual e pessoal. O primeiro é institucional, é conferido pelo cargo, pelo dinheiro, pela posição, ou seja, por fatores externos ao indivíduo que o exerce. Já o segundo seria a capacidade de estimular a participação, a habilidade de conexão pessoal, de competência interpessoal; enfim credibilidade, coerência e confiança seriam suas marcas principais. É fácil perceber que, nas organizações em geral, aquele que comanda é o poder contextual. O poder pessoal muitas vezes é subestimado, até sufocado pelo contextual. Aqui se tecem, como sugeria antes Foucault, tramas que fixam os sujeitos trabalhadores em redes de poder que os imobilizam, ao invés de movê-los. Que os faz sofrer, em vez de libertá-los e promover crescimento. (Veronese, 1999)

Percebemos, durante as apresentações e relatos realizados pelo grupo na Abrapso, que as bases materiais e de gestão muitas vezes impõem duras limitações à mudança institucional e ao desvelamento de todas essas questões. A estrutura burocrática e cristalizada é outro problema gritante. A definição de papéis, funções e competências pode ser extremamente fixa e burocrática, "amarrando" os agentes de transformação institucional em relações improdutivas e/ou de dominação, além de potencialmente produtoras de doença física e/ou mental. 


\section{Conclusões provisórias}

Fica clara a necessidade de evitarmos o "epistemicídio" (Santos, 1989), ou o ocultamento da diversidade de saberes que compõem o mundo social e, portanto a instituição. Há que revitalizar a troca produtiva entre os diferentes saberes, em busca de um paradigma de base mais democrático, ecológico e cidadão.

Os mecanismos de exclusão dos quais falava Foucault, constituem-se numa necessidade de assimilação: a dita cultura da instituição precisa ser assimilada, exigindo uma identidade muitas vezes forjada em normas não discutidas e não validadas num espaço público institucional. Quem não se enquadra, é excluído/a. Assim temos práticas de conhecimento-regulação, ou seja, baseadas no primado da ordem, da lei outorgada, da ciência tecnicista.

Precisamos do conhecimento-emancipação, aquele que se constrói no quotidiano, não em palestras de convencimento, mas nas ações que incluam a solidariedade, admitam o caos que se reconhece enquanto prática e se organiza democraticamente, numa construção dialogada e participativa (Santos, 2001). E contando com uma ciência baseada no novo posicionamento epistemológico, que não abre mão da técnica, desenvolvendo-a tanto quanto possível sempre, mas sem fetichizá-la e totalizá-la.

A Psicologia pode ajudar a implementar um projeto pedagógico que mexa com a disposição das condutas regulares, que incentive o resgate da cidadania e do saber-ser, da competência ampla que inclui a ética como elemento constituinte fundamental, junto com a técnica (Panceri, 1997).

Através das práticas inspiradas nessa nova postura epistemológica, pode-se construir competências reais (e institucionais) para que possamos atender às necessidades sociais de emancipação, humanização e cidadania, considerando a lógica do mercado (estamos inseridos nela), mas superando o reducionismo da pura submissão à mesma. Será um exercício, nada fácil, de um processo histórico de conquista da posição de atores sociais politicamente posicionados e potencialmente transformadores das instituições, contribuindo para a globalização solidária que hoje buscamos, em fóruns internacionais, e sobretudo nas práticas diárias.

\section{Bibliografia}

FOUCAULT, M. (1988). A microfísica do poder. Rio de Janeiro: Graal.

GUARESCHI, P. (1995). Sociologia da prática social. Petrópolis: Vozes.

JACQUES, M. G. C. (1999). Contribuições da psicologia social para o trabalho e as organizações. In Silveira, A., Gewehr, C., Bonin, L. F. e Bulgacov, Y. L. (orgs), Cidadania e partiçipação social. Porto Alegre: Abrapsosul.

KRAUSZ, R. (1991). O poder nas organizações.

LOURAU, R. (1975). A análise institucional. Petrópolis: Vozes MICHAELIS, (1998) Moderno dicionário brasileiro da língua portuguesa - São Paulo: Melhoramentos.

MATTOS, R. (1992). De recursos a seres humanos. Brasília: Livre.

PANCERI, R. (1997). Instituição assistencial e cidadania. Veritas, v.42, n.2, p.205-216.

REY, F. G. (1995). Personalidad, sujeto y psicologia social. In Montero, M. Construcion e crítica de la psicología social. Barcelona: Anthropos.

SANTOS, B. S. (1989). Pela mão de Alice: o social e o político na pósmodernidade. São Paulo: Cortez

SANTOS, B. S. (2001). Palestra proferida durante o Fórum Social Mundial, em Porto Alegre, Rio Grande do Sul, no auditório da Faculdade de Direito da UFRGS, em 29/01.

VERONESE, M. (1999). A noite escura e bela: um estudo sobre o trabalho noturno. Dissertação de Mestrado em psicologia social e da personalidade. PUCRS. 


\section{Psicologia comunitária e intervenções em grupos populares}

Maria Luisa Menezes

\section{Psicologia Comunitária: uma reflexão necessária}

Busco, através deste texto, provocar uma reflexão sobre alguns aspectos da inserção em grupos populares, problematizando o próprio conceito intervenção e dialogando com as buscas epistemológicas da psicologia comunitária. $\mathrm{O}$ ponto de partida desta discussão foi a apresentação dos trabalhos e as inquietações surgi das no grupo: Psicologia Comunitária e intervenções em grupos populares. Não pretendo fazer uma descrição dos relatos ou dos debates, e sim uma análise sobre esta temática.

Quando nos deparamos com a questão da intervenção, faz-se necessário, discutir sobre o projeto que desenvolvemos em relação as classes populares e por consequência, o olhar psíquico, ou seja, o sentido da psicologia neste projeto. Esta discussão tem sido feita, ao longo dos anos, sob a proteção e suporte marxista que nos fez nascer enquanto área da psicologia social e comunitária, que comprometida com um projeto de transformação social se baseou no materialismo histórico dialético (Freitas, 1998). É inegável esta contribuição e fundamentação gestada e sustentada pela ABRAPSO, assim como, novos horizontes que ora nos abre, para novas antigas reflexões.

Pesquisas na área ambiental, rural, urbana, grupos específicos, comunidades, violência, o desemprego, demonstram, um alargamento no processo de pensar a inserção que nos anuncia um campo de desordem e complexidade a ser compreendida e investigada. As apresentações e a experiência de ensino, pesquisa e extensão que venho realizando nesta área tem me levado a visão de que estamos no momento de pesquisas e trabalhos intensos que nos façam descobrir novas categorias de interpretação da realidade junto às classes populares e movimentos sociais (Melucci). Esta já é uma posição que a física quântica, mas especificamente Capra (1987), tem possibilitado às ciências humanas. Esta foi a análise que tive ao ouvir os trabalhos. A diversidade das apresentações por um lado refletiu uma desordem, indicando-nos que temos um vasto caminho de pesquisa e investigação no campo da psicologia comunitária e seus atravessamentos de classe sodal e subjetividade. As concepções teóricas que nortearam as apresentações foram a historíco-crítica e o modelo ecológico contextual.

As práticas de pesquisa e extensão apresentadas, não só neste encontro mais em tantos outros que já participei, demonstram a necessidade de pensarmos seria e corajosamente sobre os pressupostos que nos substanciam enquanto agentes, intelectuais e professores que intervêm e escreve sobre temáticas que envolvem classes populares, conhecimento científico e popular, ideologia, alienação. Melucci (2000), Touraine (1998), provoca um debate sobre as bases paradigmáticas que norteiam a teorizações e as práticas, também na psicologia, passamos por esta reflexão que discute as bases (predominantemente marxistas) que nos fundaram, aflorando uma crise necessária, sobre os nossos conceitos e concepções. Um aspecto que gostaria de destacar enquanto campo de conhecimento é da possibilidade que ora temos e necessitamos de criar nossas orientações sem contudo descartar o que nos enraíza enquanto crenças, princípio ético, teorias, epistemes, sem todavia tolher nossa criatividade existencial. Posso, por exemplo, manter como categoria de estudo e de "intervenção", classe social e trabalhar numa perspectiva da natureza (Brandão, 1994). É o direito à autonomia, ou seja, à autoria do próprio trabalho, fazendo com que saibamos mais o que estamos fazendo, integrando vivencial e analiticamente, teoria e prática.

Partindo desta concepção, que amplia nossas "intervenções", peço licença ao leitor, para, ao invés de intervenção, refletirmos sobre o termo "interação" anunciada por Boff (1999), numa mesma perspectiva que foi a problematização de Freire (1982), com o termo "extensão" sugerindo "comunicação". O termo extensão assim como intervenção sugere uma imposição de quem ocupa um determinado lugar no sentido mecânico e técnico do termo. Os conceitos orientam formas de pensar e agir, e existem, dentro de um espaço legitimado. Interação é o movimento de agir com, a partir da presença e experiência do outro. Assumir esta concepção é muito mais do que defender um termo. Aqui entramos numa visão de trabalho comunitário. O estar com significa construir um projeto conjuntamente, onde os saberes não precisam ser tão evidenciados enquanto popular e científico. É o espaço da vivência coletiva que é diferente da dinâmica de grupo. Este é apenas um dos instrumentos da interação. É um conhecimento técnico, importante, mas não central. É necessário que o psicólogo 
comunitário se identifique com o que constrói. O que queremos nós quando nos afirmamos como profissionais que trabalham em classes populares?

A potência da interação não está na intervenção, mas no processo interativo. Parece óbvio, mas não o é o suficiente para entendermos e encarnarmos o que fazemos. O vínculo vai orientando as pessoas a se expressarem e descobrirem a autonomia de serem sujeitos. A presença é fundamental. Isto leva a uma questão instigante sobre o olhar que o psicólogo tem sobre a vida e os fatos. Quando escutamos nosso imaginário, deparamos com a percepção de que o psicólogo é a9-uele que vai resolver problemas, portanto, nosso olhar está voltado para os problemas, até para continuarmos existindo. E como seria se invertêssemos a lógica, e focalizássemos a saúde.

Não é apenas um ponto metodológico. É um modo de estar com as pessoas, um estilo de viver que desorganiza e organiza novas estruturas. A psicologia comunitária se propõe a acreditar profundamente na potência e na capacidade das pessoas se estruturarem, na construção coletiva, na identidade pessoal e coletiva que vai se construindo nos movimentos sociais (Melucci, 1998). A aprendizagem com estes movimentos é contínua, e daí, surge a necessidade de uma reflexão profunda sobre as consequências de permanecer em trabalhos pontuais isolados ou afirmar-se junto aos movimentos em que nos propomos trabalhar.

A diversidade de trabalhos tem nos mostrado a importância de debruçarmos numa análise contextual, específica no sentido de aprender com cada experiência e ao mesmo tempo, construir conceitos e categorias analíticas enraizados às nossas práticas. Recuperar o sentido verídico do resgate histórico junto à comunidade, ou seja, fazer com que as pessoas tragam mais vida em suas vidas numa proposta biocêntrica (Toro, 1991), de reencantamento com a vida, de descoberta do sensível, situando o espaço enquanto lugar: situado, singular, povoado por lembranças pessoais, sítio de experiências colorido por emoções datadas. Esse espaço que se desdobra e singulariza em casa, concha, ninho, cofre, gaveta, é cenário da vida do corpo, morada dos afetos, fonte de poiésis... (Pesanha, p.156).

A comunidade, sua conceituação, interação e investigação leva-nos a discussão de Boaventura (1987), sobre o paradigma emergente, no qual o conhecimento científico aproxima-se cada vez mais. do discurso da crítica literária ou artística, ligada a um conhecimento prudente, onde ao se fazer ciência, as pessoas se constroem, como o artista que estando altamente entregue no ato de criação, permanece implicado no resultado de sua obra, desenvolvendo uma integração entre ética e estética.

O enfoque desta reflexão constrói-se na busca de uma rodução de conhecimento pautada numa "nova racionalidade" (Boaventura, 1987 p.56), numa "prática de auto-gestão... num lugar intermediário, lugar da interação e da construção conjunta. Um modelo de conhecimento que não exclua a ternura" (Restrepo, 2000 p.85)

O contexto comunitário, o desafio da psicologia se complexifica mais e mais quando optamos por uma expansão e um sentido de ciência onde a intuição e poesia caminham juntas, e resgate a vida das sociedades arcaicas, nas quais "o trabalho era acompanhado por cantos e ritmos, e enquanto preparava-se a farinha nos pilões, cantava-se ou utilizava-se esses mesmos ritmos" (Morin, 1999, p.37). Essa "nova racionalidade" provoca uma discussão antiga e profunda sobre o sentido da razão humana e a indissociável, porém negada relação entre afeto, corporeidade e racionalidade. Tenho me indagado profunda e curiosamente sobre o sentido desta negação, no qual o movimento comunitário nos instiga para uma busca de perguntas e respostas. De onde vem, por exemplo, a idéia de que a música e a dança são necessariamente instrumentos de alienação ou negação da consciência?

Ao longo dos quinze anos de observação e experiência com trabalho comunitário, tenho observado curiosamente, os interesses e relações entre lideranças comunitárias, agentes externos e os pequenos grupos e mcvimentos existentes nas comunidades. Indago-me sobre o sentido do estar ali, sobre as esperanças e desencantos, sobre a magia e a coragem dos que por opção se fazem presença nas lutas (cotidianas) da vida comunitária. Encontro cada vez mais espaços de solidariedade, onde a afetividade e as identificações têm dado sustentabilidade aso projetos sociais comunitários, como por exemplo, redes de cooperativas:

Os tempos, os ritmos, têm revelado uma riqueza sobre a diferença e identidade dos movimentos sociais e a relação estabelecida entre pesquisador, agente, comunidade no deciframento sobre a construção de nossos conhecimentos. 
Existe um tempo reconhecido entre nós, o da experiência, onde passado, presente e futuro se interfluenciam sem uma progressão linear e determinante, que para Melucci (1996), não é o tempo do relógio, é o ritmo vinculado a uma dimensão da natureza, da respiração, da surpresa e da construção, portanto da autonomia. O ritmo, vivência do tempo, quando respeitado, visualizado, permite que as pessoas se movimentem em escolhas baseadas na descoberta dos sonhos, no desejo, nas emoções e naturalmente, esbarrem nas regras e no tempo social. Portanto, abrir esta discussão e mais do que isso, acreditar e lutar para que as pessoas vivam seus tempos (ritmos), significa desvelar uma grande divisão entre a experiência individual e o ritmo social, entre a qualidade do tempo vivido e as exigências e os significados da chegada. Tempos fragmentados, patologias são a consequência direta da perda de uma unidade temporal, que através das drogas, a juventude busca encontrar a expansão do tempo interior, o elo perdido e a consciência de onde realmente estamos. Ou seja, resgatar a qualidade da vivência de sentir-se uno, ligado, onde a corporeidade é o espaço vivido de nossos próprios limites (Melucci,1996). Ou seja, da identidade constituída na relação tempo-ritmo, a qual possibilita a construção de pequenas redes (universidade, comunidade, pessoas, movimentos sociais).

Esta breve e introdutória discussão tem como objetivo suscitar nos profissionais e estudantes, o desejo de diálogo e aprofundamento, numa reflexão que envolve mudanças de paradigmas, na interligação entre corporeidade, tempo-ritmo, identidade coletiva, para que se possa resgatar o sentido primeiro da psicologia comunitária, onde teoria e prática se retroalimentam, possibilitando-nos um espaço de recriação de práticas e conceitos que fundamentam e estruturam a área de psicologia comunitária baseada na busca de transformação social, que ora se apresenta com novas (outras) matizes. E que o espírito artístico e poético possa nos iluminar enquanto agentes e pesquisadores no sentido de compreender a poética de Bachelard (1993), "Portanto, é preciso que o saber seja acompanhado de um igual esquecimento de um saber. $\mathrm{O}$ não-saber não é uma ignorância, mas um ato difícil de superação do conhecimento" (p.16), rumo a um diálogo intenso da diversidade, que ora nos cercam na busca diferenciada de uma vida que nos dignifique como seres vivos e não mais como seres que assistem passivamente a morte lenta, gradual e tão sofrida de nossa espécie.

\section{Manifesto para uma atualização da Psicologia Social}

Gregório Baremblitt

A Psicologia Social, na sua versão mais conspícua, contemporaneamente vigente, nasceu nos Estados Unidos, principalmente a partir da contribuição de intelectuais e cientistas emigrados da Europa na década de quarenta.

Suas principais fontes teóricas foram, com diversos graus de influência: na vertente Psicológica - a Psicanálise, o Comportamentalismo, a Teoria da Gestalt, o Psicodrama e a Reflexologia; na vertente sociológica - a estirpe de Comte (Weber, Durkheim e Pareto), com contribuições de Marx, Tarde, MacDougall e outros.

Sua modalidade predominante foi a baseada na Teoria de Campo de Kurt Lewin, assim como, num sentido mais amplo, o EstruturalFuncionalismo de Parsons e outros autores, não obstante existir inumeráveis matizes e diversas orientações.

Suas primeiras aplicações tiveram a ver com problemas do âmbito do Trabalho, do Consumo e do Preconceito, sendo seu dispositivo operacional prevalecente, em princípio, os pequenos grupos e, depois, as pesquisas de massas, ligadas predominantemente a questões demográficas e ao marketing comercial e eleitoral.

Sua definição de Psiquismo, assim como a de Sociedade, tem variado de acordo com a orientação ético-político-epistemológica de origem, sendo as mais pregnantes as comprometidas com a investigação e a solução das contradições causadoras e resultantes da plena implantação das formações econômicas capitalistas modernas e com o sistema da democracia chamada "formal", representativa, republicana e federativa.

O marco mundial em que esta Psicologia Social desenvolveu-se foi o dos conflitos entre as citadas democracias e o nacionalismo-socialismo, na segunda guerra mundial e depois do pacto de Yalta, entre o capitalismo americano e europeu, o bloco socialista real e os capitalismos tardios ou dependentes. Dito desde outro ângulo: acompanhou e participou na problemática da passagem do colonialismo clássico ao neo-colonialismo (tanto do imperialismo capitalista como do social-imperialismo soviético) e, 
finalmente, ao da globalização neoliberal contemporânea do Capitalismo planetário integrado (incluindo nele as variedades social-democráticas, os eurocomunismos, os comunismos em vias de capitalização, etc.).

Pode-se dizer que, não sem matizes importantes, a Psicologia Social predominante, nasceu e cresceu inspirada na razão, nos interesses e nos desejos do Estado e do Capital (Capital privado e/ou Capitalismo de Estado) embora que manifestamente dedicada aos da Sociedade Civil e aos ditos "Populares".

A Psicologia Social se constituiu e existe como uma Disciplina e as duas "figuras" jurídico-epistemológicas que lhe são inerentes, tal como a conhecemos, são as da Profissionalidade e da Especificidade. A primeira, como institucionalização da legalidade desta prática, dentro da divisão técnica e social do trabalho; a segunda, como constância da cientificidade e do reconhecimento acadêmicocorporativo desse saber e da idoneidade dos seus agentes. Essas "figuras", que dentro da "natureza" das formações de soberania modernas têm como valores essenciais a legitimação e a neutralidade, são a fiel expressão do direito positivo e de determinada concepção instrumentalista e utilitária da ciência. Em consequência, elas são compenetradas e são partícipes ativas (embora que diferenciadas e contraditórias), de todos os "defeitos" e "virtudes" axiomáticos e concretos, do Estado e do Capital, entre os que prevalecem: a preservação da propriedade e da pessoa dos proprietários, a acumulação-concentração da riqueza, do poder e do prestígio e, em última instância, a produção e a conversibilidade mercadológica de quanto existe, no Equivalente Geral Dinheiro.

Obviamente, nunca faltou, nessas éticas, teoria e práticas, um pólo, ou bem "humanitário", ou progressista, ou até "revolucionário" (seja como for que se entendam tais denominações).

Jamais foi a mesma coisa trabalhar em Psicologia Social para os serviços de inteligência dos terrorismos de Estado, ou para o incremento artificial da competitividade da produção e consumo mercantis, do que para sindicatos combativos, associações comunitárias ou para a realização do que puder ter de bom nas políticas públicas de educação, saúde e bem-estar coletivo em geral. Houve Psicólogos Sociais que, fosse qual fosse a inventividade e singularidade de suas escolas (amiúde surpreendentemente pobres), dera, até sua vida em defesa do que de melhor tem a democracia formal ou alguma concepção falida do socialismo.

Ultimamente, dentro do polimorfo, bizarro e desigual panorama da pós-modernidade, a Psicologia Social tem se sofisticado com matizes tomados dos recursos teóricos e técnicos da comunicação, da informática, da cibernética, da telemática, dos sistemas, da complexidade e, em geral, do chamado novo paradigma. Mas, tais avanços não têm mostrado por si mesmos, ser garantia alguma da decidida aposta da Psicologia Social a serviço das "minorias maioritárias" exploradas, dominadas, mistificadas e "descartáveis", que as crises estruturais do capitalismo planetário integrado "triunfante" tem multiplicado no mundo inteiro.

A taxativa e exponencial assimetria entre o "Norte" hipertrófico e o "Sul" agonizante, o incremento da desigualdade na distribuição da renda e de todos os benefícios civilizatórios, a miséria e a pobreza, o desemprego, a morbimortalidade, e a delinquência "pandêmicas", a discriminação etária, sexual, racial e as guerras locais generalizadas exigem desesperadamente (entre milhares de mutações), a crítica e a reformulação radicais das disciplinas "científicas": sua concepção de especificidade, de profissionalidade, sua ética, teoria, técnica e práxis.

Começa a ser notório, no mundo inteiro, a proliferação das chamadas entidades do terceiro setor (não estatal e não privado), assim como as dos movimentos e organizações populares, de inspiração auto-analítica e autogestionária que, aliadas aos pólos e segmentos autenticamente implicados da democracia formal (partidários, religiosos, culturais, etc.) lutam pela construção de uma Nova Terra, justa, livre e solidária.

Neste novo mundo, a redefinição e reinvenção do que é Subjetividade e Sociabilidade é um aspecto de incalculável importância e, a participação de inéditas versões do que era a Psicologia Social se tornam imprescindíveis para deter o genocídio, a depredação da natureza e a distorção mercantil do parque tecnológico.

Estas tentativas de atualização da Psicologia Social sob um paradigma ético-estético-político-neo-científico já existem, apesar de estarem longe deter adquirido a difusão e a aplicação que se precisa. Mas sua atualização não deve ser entendida no sentido de uma hiper modernização e um aggiornamento mercenário, cada vez mais 
organicamente compenetrado com os interesses e desejos (empresariais, estatais, acadêmicos, etc.) da axiomática do Capital. Atualização da Psicologia Social (assim como de todos os equipamentos da sociedade Pósindustrial) deve ser compreendida no sentido bergsoniano de Atualização das potências do Virtual, ou, como dizem Deleuze e Guattari, na plena efetuação das formidáveis pré-energias e pré-forças do Processo da produção Desejante, que são o âmago de uma realidade na qual "tudo" é "possível".

$\mathrm{Na}$ década de sessenta, Herbert Marcuse dizia que "a era da abundância já tinha chegado", significando que a potência produtiva da realidade moderna já tinha atingido a capacidade de solucionar os principais problemas que afetavam a população mundial. Em quarenta anos, o capitalismo mundial integrado conseguiu capturar predominantemente tais capacidades colocando-as a serviço exclusivo de que "o dinheiro produza dinheiro". Para consegui-lo, foi uma mola fundamental a reprodução de subjetividades e sociabilidades que fossem funcionais a esses objetivos, assim como o de marginalizar, desqualificar ou eliminar as que não o eram.

Atualizar a Psicologia Social implica transmuta-la em dispositivos de produção de subjetivação e de socialização singulares, extraordinariamente diferentes dos preconizados como "universais", "invariantes" e "exclusivos", tanto pela "mídia", a "cultura", ou a "ideologia" dominante, como pelas disciplinas cientificistas a-críticas.

Os agentes da Psicologia Social não tardarão em se convencer de que, ou se agenciam implicadamente nos dispositivos de luta pela Utopia Ativa da Nova Terra, e/ou se inserem como discretos militantes "infiltrados" na parafernália do Estado e do mercado... ou serão partícipes, co-responsáveis (e de alguma forma vítimas) da catástrofe assintótica (ou seja, incessante e sem final), que o Capitalismo planetário reserva para a imensa maioria dos seres vivos. 